\title{
De arbeidsmarktperspectieven van studierichting in het wetenschappelijk onderwijs 1992 : arbeidsmarktmodule i-see project
}

Citation for published version (APA):

de Grip, A., Heijke, J. A. M., Dekker, R., Groot, L. F. M., \& Vos, L. A. (1987). De

arbeidsmarktperspectieven van studierichting in het wetenschappelijk onderwijs 1992 :

arbeidsmarktmodule i-see project. Researchcentrum voor Onderwijs en Arbeidsmarkt, Faculteit der Economische Wetenschappen. ROA Reports No. 3 https://doi.org/10.26481/umarep.1987003

Document status and date:

Published: 01/01/1987

DOI:

10.26481/umarep.1987003

Document Version:

Publisher's PDF, also known as Version of record

Please check the document version of this publication:

- A submitted manuscript is the version of the article upon submission and before peer-review. There can be important differences between the submitted version and the official published version of record.

People interested in the research are advised to contact the author for the final version of the publication, or visit the DOI to the publisher's website.

- The final author version and the galley proof are versions of the publication after peer review.

- The final published version features the final layout of the paper including the volume, issue and page numbers.

Link to publication

\footnotetext{
General rights rights.

- You may freely distribute the URL identifying the publication in the public portal. please follow below link for the End User Agreement:

www.umlib.nl/taverne-license

Take down policy

If you believe that this document breaches copyright please contact us at:

repository@maastrichtuniversity.nl

providing details and we will investigate your claim.
}

Copyright and moral rights for the publications made accessible in the public portal are retained by the authors and/or other copyright owners and it is a condition of accessing publications that users recognise and abide by the legal requirements associated with these

- Users may download and print one copy of any publication from the public portal for the purpose of private study or research.

- You may not further distribute the material or use it for any profit-making activity or commercial gain

If the publication is distributed under the terms of Article 25fa of the Dutch Copyright Act, indicated by the "Taverne" license above, 
DE ARBEIDSMARKTPERSPECTIEVEN VAN

STUDIERICHTINGEN IN HET

WETENSCHAPPELIJK ONDERWIJS 1992

-Arbeidsmarktmodule I-SEE project-

ROA-R-1987/3
A. de Grip
J.A.M. Heijke
R.J.P. Dekker
L.F.M. Groot
L.A. Vos

RESEARCHCENTRUM VOOR ONDERWIJS EN ARBEIDSMARKT

Faculteit der Economische Wetenschappen

Rijksuniversiteit Limburg

Maastricht, november 1987 
niets uit deze uitgave mag worden verveelvoudigd en/of openbaar gemakt door middel van druk, fotocopie, microfilm of op welke andere wijze ook, zonder voorafgaande schriftelijke toestemming van het Ministerie van Sociale Zaken en Werkgelegenheid. In geval van overname van het data-materiaal moet telkens als bronvermelding worden vermeld: "Researchcentrum voor Onderwijs en Arbeidsmarkt" of "ROA". 
INHOUDSOPGAVE

Bladzijde

Voorwoord 2

1 Inleiding 3

2 Historische data en arbeidsmarktindicatoren 8

2.1 Arbeidsmarktdata en historische trends 8

2.2 Vervangingsbehoefte en absorptiegraad beroepen 10

2.3 Branchespreiding en conjunctuurgevoeligheid beroepen 12

$\begin{array}{lll}2.4 & \text { Beroepenspreiding van studierichtingen } & 14\end{array}$

3 Arbeidsmarktprognoses 1985 - $1992 \quad 16$

3.1 Werkgelegenheidsprognoses 16

3.1.1 Prognoses naar bedrijfssectoren 16

3.1.2 Prognoses naar beroepsklassen 17

3.1.3 Prognoses naar studierichtingen 22

3.2 Prognose vervangingsvraag 25

3.2.1 Vervangingsuraag per beroepsklasse 26

3.2.2 Vervangingsvraag per studierichting 28

3.3 Vraag naar schoolverlaters per beroepsklasse 29

3.4 Totale vraag naar arbeid 30

3.5 Prognose aantal afstuderenden 31

Typering arbeidsmarktsituatie naar studie-
richting

4 Arbeidsmarktperspectieven beroepen en 35

4.1 Typering beroepsklassen 35

4.2 Typering studierichtingen 39

$\begin{array}{lll}5 & \text { Besluit } & 40\end{array}$

Literatuur 43

Bijlage I : Arbeidsmarktdata studierichtingen

Bijlage II : Arbeidsmarktdata beroepsklasse en

Bijlage III : Classificatie-criteria

historische trends 
VOORWOORD

In dit onderzoeksrapport wordt verslag gedaan van een onderzoek naar de arbeidsmarktontwikkelingen in het recente verleden en de arbeidsmarktverwachtingen voor de nabije toekomst van de verschillende studierichtingen binnen het Wetenschappelijk Onderwijs.

Het hier gepresenteerde onderzoek is het vervolg op het eerder uitgebrachte rapport "Inventariserend onderzoek arbeidsmarktmodule I-SEE project" (ROA-R-1987/1, februari 1987). Doel van het onderzoek is het invullen van de arbeidsmarktmodule van het geautomatiseerde informatiesysteem 'I-SEE'.

Het onderzoek is door het Researchcentrum voor Onderwijs en Arbeidsmarkt (ROA) van de Rijksuniversiteit Limburg uitgevoerd in opdracht van het Centrum voor Beleidsanalyse en Advies (CBA) te Nijmegen, dat door de Interdepartementale Stuurgroep Studie- en Beroepskeuzevoorlichting (I.S.B.V.) is belast met de ontwikkeling van I-SEE.

Het gaat hier vooralsnog om een "pilot-project", gericht op het opleveren van arbeidsmarktinformatie die van belang kan zijn bij de studie- en beroepskeuze van leerlingen in de eindexamenklassen van het VWO, die zich oriënteren op een studie binnen het Wetenschappelijk onderwijs.

Het onderzoek warover hier wordt gerapporteerd stond onder leiding van prof. dr. J.A.M. Heijke, directeur van het ROA. De dagelijkse leiding berustte bij dr. A. de Grip. Aan het onderzoek is verder meegewerkt door drs. R.J.P. Dekker en drs. L.F.M. Groot met assistentie van L.A. Vos. De student-assistenten G. Kloek en M.A. Mortier hielpen bij het verwerken van het datamateriaal. Evenals bij het eerdere oriënterende onderzoek, is ook ditmaal overleg gevoerd over de aard van de te presenteren data met A. Torben-Nielsen, contactpersoon namens de I-SEE projectgroep. 


\section{INLEIDING}

In dit onderzoeksrapport worden de resultaten gepresenteerd van het vervolgonderzoek op het eerdere, inventariserende, onderzoek naar arbeidsmarktinformatie die van belang kan zijn voor de studie- en beroepskeuze (De Grip, Heijke en Vos, 1987).

De opdracht voor het onderzoek werd verstrekt door het Centrum voor Beleidsanalyse en Advies te Nijmegen, in het kader van de ontwikkeling van het "Information System on Education and Employment", het zgn. "I-SEE" project. Doel van dit project is te komen tot een geautomatiseerd informatiesysteem met betrekking tot de verschillende opleidingen en beroepen.

De doelgroep van dit onderzoek is vooralsnog de groep leerlingen in de eindexamenklassen van het VWO, die zich oriënteert op een universitaire studie.

Het in deze onderzoeksnota gepresenteerde cijfermateriaal is primair bedoeld voor het invullen van de arbeidsmarktmodule van I-SEE. Daarbij is er overigens wel sprake van een duidelijk raakvlak met de beroepenmodule, voor zover er in dit rapport aangegeven wordt welke beroepen c.q. functies arbeidskrachten met een bepaalde opleidingsrichting de facto uitoefenen.

In ons eerste I-SEE rapport moest nog worden volstaan met het beschrijven van de huidige arbeidsmarktsituatie en het geven van een summiere historische schets van de ontwikkeling van de werkloosheid, het aantal schoolverlaters, e.d. Belangrijke punten in het 'wensenlijstje' van Pere (1986, p. 31), waarop in het inventariserende onderzoek nog niet kon worden ingegaan, zoals de conjunctuurgevoeligheid van beroepen en de verwachtingen ten aanzien van de ontwikkeling van 
de werkgelegenheid en de instroom van schoolverlaters, komen ditmaal wel aan bod. Bij het maken van arbeidsmarktprognoses is uitgegaan van het prognosejaar 1992, het eerste jaar waarop degenen die in 1988 beginnen aan een universitaire studie als afgestudeerde op de arbeidsmarkt kunnen instromen.

Bij de presentatie van de arbeidsmarktdata hanteren wij een indeling in een tweetal aan elkaar te relateren invalshoeken, te weten:

1. Arbeidsmarktdata studierichtingen Wetenschappelijk Onderwijs (voor 13 studierichtingen); Zie bijlage I.

2. Arbeidsmarktdata beroepen (voor 20 beroepsklassen, in verschillende gevallen aangevuld met data met betrekking tot enkele meer specifieke beroepsgroepen); Zie bijlage II.

Bij beide invalshoeken wordt achtereenvolgens ingegaan op:

- de huidige situatie en de historische ontwikkeling van het opleidings- of beroepsdomein en de werkloosheid naar opleidingsrichting;

- de berekende indicatoren;

- de arbeidsmarktprognoses 1992;

- een classificatie van de arbeidsmarktperspectieven.

De arbeidsmarktdata met betrekking tot de huidige situatie en de "historische trends" vormen een verdere uitbouw van de in het vorige onderzoek opgeleverde data. Voor de verschillende beroepsklassen wordt vervolgens een eerste indicatie gegeven van de vervangingsbehoefte en de absorptie van jongeren in het desbetreffende beroep. Daarnaast worden ook indicatoren gegeven van de conjunctuurgevoeligheid en de branchespreiding (met andere woorden de "risicospreiding") van de verschillende beroepen. Voor de studierichtingen is een indicator geconstrueerd voor de beroepenspreiding (ook hier als indicator van de flexibiliteitsmogelijkheden $c . q$. de risicospreiding). 
Daarna volgen de prognoses van de arbeidsmarktsituatie in 1992 voor de verschillende studierichtingen en beroepsklassen. Voor de beroepsklassen wordt een prognose gegeven van respectievelijk de uitbreidingsuraag, de vervangingsvraag en de vraag naar afstuderenden. Bij de verschillende studierichtingen wordt daarnaast een prognose gegeven van het aanbod van abituriënten. Op basis van deze prognoses kan een indicatie worden gegeven van de arbeidsmarktsituatie, waarmee de afstuderenden in de diverse studierichtingen in 1992 worden geconfronteerd. Tenslotte wordt voor de verschillende beroepsklassen en studierichtingen een typologie gegeven van de arbeidsmarktperspectieven. Daarbij wordt er naast de arbeidsmarktprognose voor 1992 ook gekeken naar de conjunctuurgevoeligheid van beroepen en de flexibiliteitsmogelijkheden van arbeidskrachten met een bepaald beroep of opleiding.

Al met al vormt dit een veelheid aan data die men in de besluitvorming bij de studierichtingkeuze zou kunnen betrekken. $E r$ is echter wel sprake van een bepaalde hiërarchie in de belangrijkheid van dit cijfermateriaal. Arbeidsmarktprognoses voor de nabije toekomst zijn wat dit betreft belangrijker dan de trends die in het verleden zijn opgetreden. Het meest complete plaatje wordt vanzelfsprekend gegeven in de uiteindelijke typering van de beroepen en studierichtingen, waarin de arbeidsmarktprognose voor 1992 wordt gecombineerd met de gemeten risicofactoren (conjunctuurgevoeligheid en flexibiliteitsmogelijkheden). Wanneer een leerling reeds een bepaald beroep voor ogen heeft bij het kiezen van een studierichting, kan natuurlijk in de eerste plaats gekeken worden naar de arbeidsmarktperspectieven die dat specifieke beroep biedt, maar daarnaast kan ook het totaalbeeld van de desbetreffende studierichting of de uitwijkmogelijkheden naar andere beroepen worden bekeken.

De gepresenteerde historische data zijn daarentegen ons inziens met name van belang om een beeld te kunnen vormen van de verschillende beroepen die men met een bepaalde opleiding kan uitoefenen en van de bedrijfssectoren waarin men dan zou kunnen gaan werken. De leeftijds- 
structuur geeft daarnaast een indicatie van de leeftijd waarop men een bepaald beroep zou kunnen gaan uitoefenen.

Zoals gezegd worden in dit onderzoek 13 clusters van studierichtingen onderscheiden. Alleen de werkloosheidsdata zijn verder verbijzonderd naar meer specifieke studierichtingen. Een verdere opdeling is op basis van het beschikbare datamateriaal vooralsnog niet mogelijk. De wenselijkheid van een verdergaande verfijning van de data binnen een aantal clusters is evident. Zo zou bijvoorbeeld de studierichting "medische opleidingen" verder moeten worden opgedeeld naar geneeskunde, tandheelkunde en diergeneeskunde.

Het streven naar een grotere desaggregatie van de arbeidsmarktdata mag echter geen doel op zich zijn. Het is in veel gevallen niet terecht onderscheid te maken tussen specifieke studierichtingen binnen een bepaalde faculteit, wanneer er geen sprake is van duidelijk afgebakende arbeidsmarktsegmenten 1). Beseft moet worden dat naarmate arbeidsmarktdata verder worden verfijnd de onderlinge verwisselbaarheid van zowel vraag als aanbod groter wordt. Bij de bepaling van dit flexibiliteitspotentieel gat het overigens niet alleen om de directe substitueerbaarheid of mobiliteit, mar ook om de flexibiliteit die kan voortvloeien uit kortdurende bijscholingen.

De indeling van dit rapport is als volgt. In het volgende hoofdstuk wordt eerst een beschrijuing gegeven van de opgeleverde data met betrekking tot de recente arbeidsmarktsituatie en de wijze waarop de historische trends zijn vastgesteld (paragraaf 2.1). Daarna volgt een bespreking van de geconstrueerde indicatoren voor de vervangingsbehoefte en de absorptiegraad van beroepen (paragraaf 2.2), de branchespreiding en conjunctuurgevoeligheid van beroepen (paragraaf 2.3 ) en

\footnotetext{
1) Mogelijk is dit ook reeds het geval bij het in dit rapport gemakte onderscheid tussen enerzijds economisten en bedrijfskundigen (drs.) en anderzijds econometristen en bedrijfskundigen
} 
de beroepenspreiding van de verschillende studierichtingen (paragraaf 2.4).

Hoofdstuk III beschrijft de wijze warop de arbeidsmarktprognoses tot stand zijn gekomen. Achtereenvolgens wordt ingegaan op de totstandkoming van de werkgelegenheidsprognoses naar bedrijfssectoren (paragraaf 3.1.1), beroepsklassen (paragraaf 3.1.2) en studierichtingen (paragraaf 3.1 .3 ), de prognoses van de vervangingsuraag naar beroep (paragraaf 3.2.1) en opleidingsrichting (paragraaf 3.2.2), de vraag naar schoolverlaters per beroepsklasse (paragraaf 3.3 ), de totale vraag naar arbeid in de periode 1985-'92 (paragraaf 3.4) en de (aanbod)prognose van het aantal afstuderenden in de verschillende studierichtingen (paragraaf 3.5). Paragraaf 3.6 beschrijft de wijze waarop de arbeidsmarktsituatie voor de verschillende studierichtingen in 1992 is getypeerd.

In hoofdstuk IV worden de classificatie-schema's besproken op basis warvan de verschillende beroepskiassen (paragraaf 4.1) en studierichtingen (paragraaf 4.2) zijn gekenschetst.

In het slothoofdstuk zal worden ingegaan op een aantal aspecten die van belang zijn voor een verdere verdieping van het hier gepresenteerde onderzoek.

Het datamateriaal wordt gepresenteerd in een tweetal bijlagen. Bijlage I geeft het cijfermateriaal naar studierichting, bijlage II naar beroepsklasse en enkele specifieke beroepsgroepen. Tenslotte worden in bijlage III de classificatie-criteria van de historische trends vermeld. 


\section{HISTORISCHE DATA EN ARBEIDSMARKTINDICATOREN}

\subsection{Arbeidsmarktdata en historische trends}

In dit onderzoek is geprobeerd het in het vorige onderzoek gepresenteerde historische cijfermateriaal zoveel mogelijk te vervolledigen. Het aantal studierichtingen waarover informatie wordt gegeven is van 15 tot 14 ingekrompen, doordat de studierichting huishoudkunde is samengevoegd met de andere studierichtingen aan de Landbouw Universiteit Wageningen. Deze samenvoeging was noodzakelijk vanwege de geringe omvang van het aantal werkenden met de opleidingsrichting huishoudkunde.

Ditmaal verstrekken we de informatie voor 20 beroepsklassen. Het betreft hier de beroepsklassen warin minimal 1000 academici 2) werken. Daarnaast wordt een indicatie gegeven van de omvang van het beroepsdomein van academici binnen enkele specifieke beroepsgroepen. Daarbij worden alle beroepsgroepen genoemd warin minimal $30 \%$ van het aantal werkenden universitair geschoold is. Voor de verschillende beroepsklassen geven we nu ook aan in welke bedrijfssectoren de desbetreffende arbeidskrachten werkzaam zijn.

Met uitzondering van de werkloosheidscijfers zijn alle historische data afkomstig uit de Arbeidskrachtentellingen van het CBS. Ditmaal is over de gehele linie gekeken naar de cijfers uit 1979, 1981, 1983 en 1985. Daar het hier gaat om enquête-resultaten is het vanwege de daarbij optredende steekproeffouten (zie De Grip, Heijke en Vos 1987, p. 7) ons inziens niet verantwoord de cijfers voor de verschillende jaren naast elkaar te zetten. Immers, dit zou kunnen leiden tot een onjuiste interpretatie van het optreden van bepaalde fluctuaties. We vermelden daarom telkens het gemiddelde over de periode 1979 - 1985. Om ook een

2) Hierop is een uitzondering gemaakt voor de beroepsklasse "Uitvoerende kunstenaars", omdat deze beroepsklasse relatief belangrijk is voor het kunstonderwijs. 
indruk te geven van de ontwikkeling die zich in deze periode voordoet, geven we daarnaast aan, of er sprake is van een bepaalde trendmatige ontwikkeling.

Deze trendindicatoren zijn telkens als volgt berekend:

$$
\text { Trend(index) }=\frac{\text { Data' } 83+\text { Data' } 85}{\text { Data' } 79+\text { Data' } 81} \times 100
$$

De indexcijfers die hieruit resulteren zijn iedere keer volgens een vijftal categorieën getypeerd ${ }^{3}$ ):

$$
\begin{aligned}
++ & =\text { sterk stijgend } \\
+ & =\text { stijgend } \\
0 & =\text { stabiel } \\
- & =\text { dalend } \\
-- & =\text { sterk dalend }
\end{aligned}
$$

Bij de verdeling van het aantal werkenden met een bepaalde studierichting over de verschillende beroepen hebben we evenals de vorige keer alleen de beroepsklassen vermeld, war minimaal $1 \%$ van het aantal opgeleiden werkt, omdat er bij een percentage kleiner dan $1 \%$, zoals in de vorige nota ook reeds werd opgemerkt, ons inziens geen sprake is van een reëel beroepsperspectief vanuit de desbetreffende opleidingsrichting. Wanneer er minder dan $5 \%$ of minder dan 1.000 afgestudeerden in een bepaalde beroepsklasse werken, wordt de beroepsklasse wel genoemd, maar vermelden we geen percentage. Dezelfde vuistregel is ook gehanteerd bij het aandeel van de leeftijdsgroepen en de verschillende opleidingscategorieën in het totaal aantal werkenden in een beroepsklasse.

De werkloosheidspercentages van de verschillende studierichtingen ge-

3) Bijlage 3.1 vermeldt de exacte classificatie-criteria. 
ven een goede indruk van de huidige arbeidsmarktsituatie. Met behulp van berekeningen van Dijkstra en Schut (1987) was het mogelijk ook werkloosheidspercentages te geven voor enkele meer specifieke studierichtingen. Ook hiervoor hebben we een trendindicator geconstrueerd, door de werkloosheidspercentages van 1983 - 1985 te vergelijken met die van 1979 - 1981. Daarnaast wordt een tweetal ratio's berekend. Het eerste kengetal geeft de verhouding weer tussen het werkloosheidspercentage voor de desbetreffende studierichting en het gemiddelde werkloosheidspercentage $(7.0 \%)$ van academici in 1985. Wanneer de waarde van de ratio groter is dan 1 is er derhalve sprake van een meer dan gemiddelde werkloosheid, vergeleken met andere academici. Daar de werkloosheid in ons land onder hoger geschoolden veel lager is dan onder laag opgeleiden impliceert een ratio groter dan 1 echter niet dat de werkloosheid boven het nationale gemiddelde ligt.

Het tweede kengetal vergelijkt de ontwikkeling van de werkloosheid onder afgestudeerden in de verschillende specifieke studies binnen een bepaalde opleidingssector met de ontwikkeling van de werkloosheid onder afgestudeerden van de desbetreffende opleidingssector voor de periode december 1978 - november 1986. Zo geeft bijvoorbeeld het kengetal van 1.7 voor de studie Geschiedenis aan, dat de werkloosheid binnen deze studierichting tussen 1978 - 19861.7 mal zo snel gestegen is als de werkloosheid onder afgestudeerden binnen de letterenfaculteit.

\subsection{Vervangingsbehoefte en absorptiegraad beroepen}

In ons vorige rapport berekenden we voor de verschillende beroepsklassen een eerste indicator van de relatieve vervangingsbehoefte (IRV) en een indicator van de relatieve absorptie van arbeidskrachten jonger dan 30 jaar. Beide indicatoren waren geconstrueerd op basis van de verdeling van het aantal werkenden in leeftijdsgroepen. 
Ook in dit rapport zijn deze indicatoren berekend. De indicator van de relatieve vervangingsbehoefte geeft de verhouding weer tussen het aandeel van de 50-64 jarigen in een beroepsklasse en het aandeel van deze leeftijdgroep in de totale werkgelegenheid, waarbij een correctie plaatsvindt voor de relatieve werkgelegenheidsontwikkeling (zie De Grip, Heijke en Vos 1987 , p. 10).

De indicator van de relatieve absorptiegraad van jongere arbeidskrachten geeft de verhouding weer tussen het aandeel van de arbeidskrachten onder de 30 jaar in een beroepsklasse en het aandeel van deze leeftijdgroep in de totale werkgelegenheid. Deze indicator wordt daarbij gecorrigeerd voor de geringere aantallen cohorten schoolverlaters van de hogere opleidingsniveaus (zie De Grip, Heijke en Vos, 1987, p. 10).

Voor beide matstaven gelden de volgende classificatie-criteria:

$\begin{array}{rlr}\text { IRV, IRAJ } \leq 0,5 & \text { erg klein } \\ 0,5<\text { IRV, IRAJ } \leq 0,9 & \text { klein } \\ 0,9<\text { IRV, IRAJ } \leq 1,1 & \text { gemiddeld } \\ 1,1<\text { IRV, IRAJ } \leq 1,5 & \text { groot } \\ \text { IRV, IRAJ }>1,5 & \text { erg groot }\end{array}$

Op dezelfde wijze als bij de historische data is ook voor deze beide indicatoren aangegeven of er sprake is van een bepaalde trendmatige ontwikkeling.

Zoals gezegd gaat het hier slechts om globale indicatoren. In de paragrafen 3.2 en $3.3 \mathrm{zal}$ worden aangegeven hoe we tot een meer precieze prognose zijn gekomen van de vervangingsvraag en de vraag naar schoolverlaters per beroepsklasse en studierichting voor de periode 1985-1992. 


\subsection{Branchespreiding en conjunctuurgevoeligheid beroepen}

Wanneer een bepaald beroep sterk geconcentreerd is in eén of een beperkt aantal bedrijfstakken, is de werkgelegenheidsontwikkeling van dat beroep in belangrijke mate afhankelijk van het wel en wee van deze bedrijfstakken. Een duidelijk voorbeeld daarvan is de beroepsklasse leerkrachten, waarvan $96 \%$ werkzaam is in de overheids(onderwijs)sector. Wanneer de werkgelegenheidsontwikkeling in deze sector stagneert heeft men weinig uitwijkmogelijkheden naar andere bedrijfssectoren.

Warnken (1986) heeft een maatstaf geconstrueerd die aangeeft in welke mate een beroepsklasse geconcentreerd is in een beperkt aantal bedrijfssectoren. We spreken in dit verband van de indicator van de "branchespreiding" van een beroepsklasse. Deze zgn. "Gini-Hirschman coëfficiënt" wordt als volgt berekend:

(1) $G_{i}=\left(1-\sum_{j=1}^{n} \alpha_{i j}{ }^{2}\right) \frac{n}{n-1}$

waarbij: GH = Gini-Hirschman coëfficiënt, $i=$ beroepsklasse, $j=$ bedrijfstak, $a=$ aandeel beroepsklasse in een bedrijfstak, $n=$ aantal bedrijfstakken.

De waarde van deze indicator kan uiteenlopen van 0 tot 1 . Bij een waarde van 0 is het beroep geheel geconcentreerd in 1 bedrijfstak. Een waarde van 1 duidt daarentegen op een volledige spreiding over branches. In navolging van Warnken hanteren we de volgende kwalificaties voor de mate van branchespreiding: 


$\begin{array}{ll}0,0<\mathrm{GH} \leq 0,3 & \text { kleine branchespreiding } \\ 0,3<\mathrm{GH} \leq 0,7 & \text { gemiddelde branchespreiding } \\ 0,7<\mathrm{GH} \leq 1,0 & \text { grote branchespreiding }\end{array}$

Ook hier is telkens aangegeven of er sprake is van een trendmatige ontwikkeling, op basis van een vergelijking tussen de indicatoren voor 1983 en 1985 ten opzichte van 1979 en 1981.

De branchespreiding geeft een indicatie van de uitwijkmogelijkheden van arbeidskrachten binnen een bepaalde beroepsklasse naar andere bedrijfstakken. De indicator geeft echter niet aan hoe groot de noodzaak kan zijn om naar andere sectoren uit te wijken. Een dergelijke noodzaak kan in feite op twee manieren ontstaan. In de eerste plaats door een structurele inkrimping van de werkgelegenheid in de sector waarin men werkzaam is. In de tweede plaats door conjuncturele fluctuaties in de werkgelegenheid binnen een sector.

Om een indruk te kunnen krijgen van deze laatste factor hebben we een indicator geconstrueerd van de mate warin de werkgelegenheid in een beroepsklasse conjunctuurgevoelig is. Naar analogie van NEI (1972) is eerst voor 23 verschillende bedrijfstakken een fluctuatie-index berekend over de periode 1950-1985. Deze berekening is als volgt4):

(2) $\quad F I_{j}=\frac{100}{h} \sum_{t=1}^{h} \frac{\left|F_{j t}\right|}{T_{j t}}$

waarbij: $F I_{j}=$ fluctuatie-index bedrijfstak $j, h=$ aantal waarnemingsjaren, $t=$ jaar, $F j=$ afwijking van de werkgelegenheid van de trendmatige werkgelegenheidsontwikkeling in bedrijfstak $j, T_{j}=$ trendmatige werkgelegenheidsontwikkeling bedrijfstak $j$.

\footnotetext{
4) Daarbij moest voor de cijfers na 1969 een correctiefactor worden toegepast, om deze data vergelijkbaar te maken met die van voor 1969.
} 
Vervolgens zijn voor iedere beroepsklasse de fluctuatie-indices voor alle bedrijfstakken gewogen met het aandeel van de desbetreffende beroepsklasse in de werkgelegenheid van de verschillende bedrijfstakken:

(3) $C G_{i}=\stackrel{n}{\Sigma} \quad B_{i j} F I_{j}$

$$
j=1
$$

warbij: $C_{j}=$ indicator conjunctuurgevoeligheid beroepsklasse $i, B_{i j}$ $=$ aandeel beroepsklasse $i$ in werkgelegenheid bedrijfstak $j, n=$ aantal bedrijfstakken.

Deze berekeningswijze impliceert de veronderstelling dat de werkgelegenheid van de verschillende beroepen binnen een bedrijfstak in gelijke mate fluctueert. In de praktijk is dit natuurlijk lang niet altijd het geval.

Voor de typering van de mate van conjunctuurgevoeligheid hanteren we de volgende kwalificaties (uitgaande van een gemiddelde van $13,1 \%$ ):
$0 \% \leq C G<5 \%$
erg kleine conjunctuurgevoeligheid
$5 \% \leq C G<10 \%$
kleine conjunctuurgevoeligheid
$10 \% \leq C G<15 \%$
gemiddelde conjunctuurgevoeligheid
$15 \% \leq C G<20 \%$
grote conjunctuurgevoeligheid
CG $\geq 20 \%$
erg grote conjunctuurgevoeligheid

\subsection{Beroepenspreiding van studierichtingen}

Op soortgelijke wijze als bij de bedrijfstakkenspreiding van een beroepsklasse, is ook de beroepenspreiding van de verschillende studierichtingen te bepalen. Daarbij zijn 83 beroepsklassen onderscheiden. 
richtingen te bepalen. Daarbij zijn 83 beroepsklassen onderscheiden.

(4) $G H_{k}=\left(1-\sum_{i=1}^{m} \gamma_{k i}{ }^{2}\right) \frac{m}{m-1}$

waarbij: $\mathrm{GH}_{k}=$ Gini-Hirschman coëfficiënt van studierichting $k, V_{k j}=$ aandeel van studierichting $k$ in beroepsklasse $i, m=$ aantal beroepsklassen.

Ook hier is gekeken of er in het recente verleden sprake is geweest van een trendmatige ontwikkeling.

Deze beroepenspreidingsindicator geeft aan wat de arbeidsmarktflexibiliteit is van een bepalde studierichting. Enerzijds wordt een indruk gekregen van de mate waarin de kans op werk met een bepaalde opleiding afhankelijk is van de werkgelegenheidsontwikkeling binnen een bepaalde beroepsklasse. Anderzijds wordt uitgedrukt hoeveel kanten een leerling op kan als hij of zij de desbetreffende studie heeft afgesloten. Daarbij moet wel bedacht worden dat we hier spreken over (brede) clusters van studierichtingen, hetgeen in bepaalde gevallen kan leiden tot een overschatting van het flexibiliteitspotentieel van een meer specifieke studierichting.

Voor de typering van de mate van beroepenspreiding hanteren we dezelfde matstaven als bij de branchespreiding:

$0,0<\mathrm{GH} \leq 0,3 \quad k$ keine beroepenspreiding

$0,3<\mathrm{GH} \leq 0,7 \quad$ gemiddelde beroepenspreiding

$0,7<\mathrm{GH} \leq 1,0 \quad$ grote beroepenspreiding 


\section{ARBEIDSMARKTPROGNOSES 1985-1992}

\subsection{Werkgelegenheidsprognoses}

In deze paragraaf zal worden ingegaan op de wijze waarop de werkgelegenheidsprognoses voor 1992 totstandgekomen zijn. We zijn daarbij als volgt te werk gegaan. Eerst is in samenspraak met het Centraal Planbureau (CPB) een prognose gemaakt voor de werkgelegenheid voor 23 bedrijfssectoren in 1992 (paragraaf 3.1.1). Deze bedrijfstakprognose heeft als basis gediend voor een prognose van de werkgelegenheid voor 83 beroepsklassen (paragraaf 3.1.2). Deze beroepsklasse-prognoses zijn vervolgens het uitgangspunt geweest voor een prognose van de werkgelegenheid naar 13 studierichtingen (paragraaf 3.1.3).

\subsubsection{Prognoses naar_bedrijifs $\underline{\text { sectoren }}$}

In de middellange-termijn raming van het CPB (1986) wordt een prognose gegeven van het arbeidsvolume (in mensjaren) in 23 bedrijfstakken in 1990. Voor de jaren 1986 en 1987 kunnen deze prognoses worden geactualiseerd op basis van het Centraal Economisch Plan 1987 (CPB 1987). Daarnaast is in overleg met het CBP verondersteld dat de ontwikkeling van de sectorale arbeidsvolumes in de jaren 1990-1992 niet afwijkt van de in de middellange-termijn raming voor 1990 geprognosticeerde groeipaden.

Om de arbeidsvolume-ramingen om te zetten in een prognose van het aantal werkzame personen heeft een ophoging plaatsgevonden op basis van de in de middellange-termijn raming voor 7 bedrijfssectoren voorspelde verschillen tussen de ontwikkeling van het arbeidsvolume en het aantal werkzame personen. Daar met name het proces van arbeidsduurverkorting, maar ook de groei van de deeltijdarbeid, momenteel enigszins lijkt af 
te nemen, is verondersteld dat de door het CPB geraamde daling van de gemiddelde werktijd per arbeidskracht voor de periode 1985-1990 zich zal spreiden over de periode 1985-1992. In overleg met het CPB zijn daarnaast nog een tweetal kleine correcties aangebracht in de werkgelegenheidsprognoses voor het bank- en verzekeringswezen en de medische en veterinaire diensten.

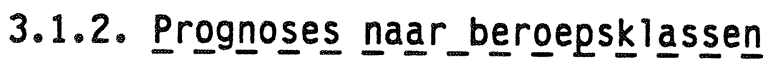

De sectorale werkgelegenheidsramingen zijn vervolgens nader gespecificeerd naar 83 beroepsklassen. Daarbij is uitgegaan van twee hypothesen. De eerste hypothese veronderstelt dat een bepalde beroepsklasse sneller in een bedrijfstak kan penetreren, wanneer de werkgelegenheid in een sector sterker groeit. Of, in het omgekeerde geval, dat het aandeel van een bepaalde beroepsklasse in de sectorale werkgelegenheid sneller terugloopt, wanneer de werkgelegenheid in de desbetreffende sector sterker afneemt. Deze hypothese zou kunnen worden aangeduid als de absorptie- of uitstotingssnelheidshypothese.

De tweede hypothese veronderstelt dat het aandeel van een bepaalde beroepsklasse sneller toe- of afneemt, naarmate het productieproces sterker beinvloed wordt door technologische ontwikkelingen. We spreken in dit verband van de technische-ontwikkelingshypothese.

Het toetsen van beide hypothesen is slechts bedoeld als een eerste aanzet voor een theoretische onderbouwing van het optreden van verschuivingen in de sectorale beroepenstructuur. Ons inziens biedt een dergelijke aanpak belangrijke voordelen ten opzichte van de in eerdere studies (NEI 1986, Ministerie van Sociale Zaken en Werkgelegenheid 1987) gehanteerde methodiek, waarin louter trendmatige ontwikkelingen worden geëxtrapoleerd. Deze laatste aanpak impliceert immers dat ontwikkelingen in het nabije verleden, waronder die ten gevolge van de 
verschillende aanpassingsprocessen op de arbeidsmarkt, zonder meer worden doorgetrokken naar de toekomst.

Ook de mogelijkheden tot toetsing van beide hypothesen zijn momenteel nog uiterst beperkt. Immers, de aandelen van de verschillende beroepsklassen zijn alleen bekend uit de zes sinds 1975 gehouden Arbeidskrachtentellingen. Het geringe aantal waarnemingsjaren maakt het slechts mogelijk beide hypothesen te toetsen door middel van enkelvoudige regressie-analyses. Wanneer er voor een beroepsklasse binnen een bedrijfssector geen significant verband wordt geconstateerd tussen de ontwikkeling van het werkgelegenheidsaandeel en een van beide verklarende variabelen, is er alsnog gekeken of er sprake is van een trendmatige ontwikkeling van het werkgelegenheidsaandeel. De gedachte hierachter is dat de trend als een 'proxy' kan fungeren voor de vooralsnog niet adequaat getoetste werking van aanpassingsmechanismen op de arbeidsmarkt.

Daar voor elke sector de som van de prognoses van de werkgelegenheid in de afzonderlijke beroepsklassen moet optellen tot de in paragraaf 3.1.1. beschreven sectorale werkgelegenheidsprognose, is gekozen voor een verdeelmodel (zie ook NEI 1986). Daartoe is voor iedere sector een referentieberoepsklasse gekozen, die in de periode 1975-1985 een redelijk stabiel werkgelegenheidsaandeel vertoonde en bovendien qua omvang niet te groot of te klein was. Tussen sectoren kunnen de referentieberoepen echter verschillen. Bij de te schatten vergelijkingen is gekozen voor de volgende vorm 5 ).

5) Om te voorkomen dat het verhoudinggetal $E_{i j} / E_{Z j}$ negatieve waarden aanneemt, is van dit verhoudingsgetal de natuurlijke logaritme
genomen. 
(5) $\ln \left(\frac{E_{i j}}{E_{z j}}\right)=\eta_{i j}+\lambda_{i j} x_{j}+u_{i j}$

waarbij: $E_{i j}=$ aantal werkzame personen in sector $j$ met beroep $i$, $E_{z j}=$ aantal werkzame personen in sector $j$ met het referentieberoep $z$, $x_{j}=$ sectorspecifieke verklarende variabele of een trendvariabele, $\eta_{i j}$, $\lambda_{i j}=$ regressie coëfficiënten en $u_{i j}=$ storingsterm.

In deze specificatie wordt de ontwikkeling van de werkgelegenheid van beroep $i$ in sector $j$ afgezet tegen de werkgelegenheidsontwikkeling van het referentieberoep in dezelfde sector. De geschatte coëfficiënten geven daarbij aan in hoeverre de desbetreffende beroepsklasse zich verschillend ontwikkeld heeft ten opzichte van het referentieberoep.

Met uitzondering van de referentieberoepen zijn er voor iedere beroepsklasse binnen iedere bedrijfssector tien verschillende regressievergelijkingen geschat. Daarbij zijn drie groepen van verklarende variabelen onderscheiden.

De eerste groep betreft de vanuit de absorptie- of uitstotingssnelheidshypothese geformuleerde verklarende variabelen. De verklaringskracht van deze hypothese wordt geanalyseerd op basis van de sectorale werkgelegenheidsontwikkeling, weergegeven door vier indicatoren, die elk afzonderlijk als verklarende variabele kunnen fungeren: het werkgelegenheidsniveau $\left(E_{j}\right)$, de logaritme daarvan ( $\left.n E_{j}\right)$, de absolute verandering van de werkgelegenheid tussen twee waarnemingsjaren $\left(\Delta E_{j}\right)$ en de procentuele werkgelegenheidsverandering $\left(E_{j}\right)$. Deze verklarende variabelen zijn alleen opgevoerd voor zover de werkgelegenheid in een sector zich in de periode 1975-1985 in dezelfde richting ontwikkelde, als de voorspelling voor de periode 1985-1992.

Het tweede cluster variabelen staat voor de technische ontwikkelingshypothese. Als proxy-variabelen voor de mate warin technologische 
ontwikkelingen de produktieprocessen in een sector vernieuwen hanteren we de sectorale arbeidsproduktiviteit, de logaritme daarvan of de procentuele verandering van de arbeidsproduktiviteit.

Voor zover verschuivingen in de sectorale beroepenstructuur niet op basis van bovenstaande sectorspecifieke variabelen kunnen worden verklaard, maar deze structuur in de onderzochte periode toch een duidelijk ontwikkelingspatroon vertoont, is door middel van trendvariabelen onderzocht of de te verklaren variabele toch een bepaalde trendmatige ontwikkeling vertoont. Daarbij zijn regressies uitgevoerd met drie functies van de tijd: $t, \ln (t)$ en $1 / t$.

Op basis van de in bovenstaande regressie-analyses gevonden verbanden zijn de aandelen van de verschillende beroepsklassen in de sectorale werkgelegenheid in 1992 berekend. Daarbij is een viertal uitgangspunten gehanteerd:

1. Regressies zijn alleen uitgevoerd voor zover er in alle waarnemingsjaren minimaal 500 personen in een beroepsklasse binnen een sector werkzaam waren. Dit is gedaan vanwege de relatief zeer brede betrouwbaarheidsmarges die bij kleine groepen in acht moeten worden genomen.

2. Zoals gezegd is steeds wanneer een van de sectorspecifieke verklarende variabelen een significante verklaringskracht heeft, hieraan de voorkeur gegeven ten opzichte van een trendvariabele.

3. Wanneer meer sectorspecifieke variabelen significant zijn, is telkens gekozen voor de vergelijking met de hoogste correlatiecoëfficiënt $\left(R^{2}\right)$. Ditzelfde criterium wordt ook toegepast, wanneer gekozen moet worden tussen meerdere significante trendvariabelen.

4. Indien er geen significante verbanden zijn gevonden, wordt verondersteld dat de (log-getransformeerde) verhouding tussen de werkgelegenheid in een beroepsklasse en het aantal werkenden in het 
referentieberoep in 1992 gelijk is aan het gemiddelde over de periode 1975-1985, tenzij er in deze laatste periode toch een duidelijke verschuiving in dit verhoudingsgetal heeft plaatsgevonden. In dat geval wordt de verhouding voor 1992 gelijkgesteld aan de verhouding in 1985.

In een beperkt aantal gevallen, waarin er sprake is van een irreële uitschieter in de voorspelling vanuit de op basis van bovenstaande uitgangspunten geselecteerde voorkeursvergelijking, is enigszins van deze beslisregels afgeweken.

Wanneer de prognose voor 1992 plaatsvindt op basis van het gevonden verband met een sectorspecifieke verklarende variabele, wordt de waarde van $\ln \left(E_{i j} / E_{z j}\right)$ voor 1992 berekend door de prognosewaarde voor de sectorspecifieke variabele in 1992 in de vergelijking in te vullen. Wanneer wordt uitgegaan van een significante trendvariabele wordt de vastgestelde trend naar het jaar 1992 geëxtrapoleerd. In de overige gevallen wordt de in de vierde beslisregel geformuleerde procedure gevolgd.

Met behulp van de volgende formule kunnen de prognosewaarden van $E_{i j} / E_{z j}$ worden omgezet in prognoses van de werkgelegenheid in de verschillende beroepsklassen binnen een bedrijfssector:

(6) $\hat{E}_{i j}=\frac{}{1+\sum_{i \neq z}\left(\hat{E}_{i j} / \hat{E}_{z j}\right)} \hat{E}_{j}$

Een sommatie over de verschillende sectoren geeft vervolgens de voorspelde totale werkgelegenheid in een beroepsklasse in 1992: 
(7) $\hat{E}_{i}=\sum_{j=1}^{23} E_{i j}$

In bijlage II is voor 20 beroepsklassen de verwachte toename van het aantal werkzame personen in de periode 1985 - 1992 uitgedrukt in een percentage van het aantal werkenden in 1985. Aan de gevonden procentuele werkgelegenheidsontwikkelingen (E) zijn de volgende kwalificaties toegekend (uitgangspunt daarbij is een macro-economische groei van de werkgelegenheid van ca. $10 \%$ ):

$$
\begin{array}{rll}
\dot{E} & \geq 20 & \text { erg hoog } \\
12 \leq \dot{E}<20 & \text { hoog } \\
8 \leq \dot{E}<12 & \text { gemiddeld } \\
0<\dot{E}<8 & \text { laag } \\
\dot{E}<0 & \text { dalend }
\end{array}
$$

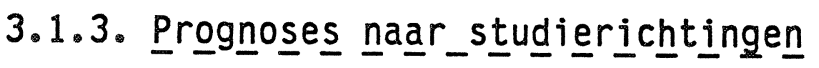

De prognoses van de werkgelegenheid naar beroepsklassen worden vervolgens als uitgangspunt genomen voor de werkgelegenheidsprognoses voor de 13 studierichtingen waarin het Wetenschappelijk Onderwijs kan worden opgedeeld. Naar analogie van de vorige stap, waarin de beroepenstructuren van de verschillende sectoren werden bepaald, wordt nu een schatting gemaakt van de opleidingsstructuur van de verschillende beroepsklassen in 1992.

Het data-materiaal waarop een dergelijke prognose kan worden gebaseerd, beperkt zich tot de Arbeidskrachtentellingen van 1979-1985, aangezien het CBS in de Arbeidskrachtentellingen van 1975 en 1977 een niet vergelijkbare onderwijsindeling hanteerde. Daar alleen gekeken wordt naar de werkgelegenheidsontwikkelingen voor afgestudeerden in 
het Wetenschappelijk Onderwijs, is het hier niet noodzakelijk uit te gaan van een verdeelmodel, maar kan direct gekeken worden naar de ontwikkeling van het aandeel van een studierichting in de werkgelegenheid binnen een beroepsklasse.

Ook voor deze stap in het prognosemodel is getracht een verklaringsgrond te vinden voor verschuivingen in het aandeel van een bepaalde opleiding in de werkgelegenheid in een beroepsklasse. In principe kan daarbij een tweetal processen worden onderscheiden. In de eerste plaats kunnen de hoger geschoolden de lager opgeleiden in dezelfde opleidingsrichting uit een beroep verdringen. We kunnen in dit verband spreken van neerwartse verdringing (De Grip 1987). In de tweede plaats kan er sprake zijn van een proces van horizontale substitutie, warin de groei van het aandeel van een bepaalde opleiding ten koste gaat van het aandeel van een andere studierichting van hetzelfde opleidingsniveau. Voor het maken van een werkgelegenheidsprognose is het niet noodzakelijk beide processen afzonderlijk te analyseren.

Net als in de vorige paragraaf veronderstellen we hier dat er een grotere verschuiving in het opleidingsaandeel in de werkgelegenheid plaatsvindt naarmate de totale werkgelegenheid in een beroepsklasse sterker toeneemt. Ook hier kunnen we derhalve weer spreken van een absorptie-of uitstotingssnelheidshypothese. In deze hypothese wordt overigens alleen gekeken naar het 'pull-effect' van het neerwartse verdringings- c.q. substitutieproces. Het geringe aantal waarnemingsjaren maakt het vooralsnog niet mogelijk naast dit 'pull-effect', ook het 'push-effect' van verschuivingen in de opleidingsstructuur van het arbeidsaanbod in de analyse te betrekken.

De schatting van het opleidingsaandeel in de werkgelegenheid in een beroepsklasse vindt plaats op basis van de volgende regressievergelijking: 
(8) $E_{k i} / E_{j}=\theta_{k j}+\psi_{k j} x_{j}+u_{k j}$

waarbij: $E_{k \mathfrak{j}} / E_{\mathfrak{j}}=$ aantal werkzame personen met opleiding $k$ in beroep $i$ ten opzichte van het totaal aantal werkenden in beroep $i, \theta_{k i}$, $\psi_{k i}=$ regressiecoëfficiënten en $u_{k j}=$ storingsterm.

Voor elke studierichting binnen iedere beroepsklasse zijn vijf vergelijkingen geschat op basis van de vier waarnemingsjaren in de periode 1979 - 1985. De in de eerste twee vergelijkingen getoetste verklarende variabelen zijn de vanuit de absorptie- of uitstotingssnelheidshypothese (neerwaartse verdringing en/of substitutie) geformuleerde variabelen: respectievelijk het werkgelegenheidsniveau in de beroepsklasse $\left(E_{j}\right)$ en de logaritme daarvan $\left(\ln \left(E_{\mathfrak{j}}\right)\right)$.

Wanneer deze beroepsspecifieke variabelen geen significante verklaringskracht blijken te hebben voor de ontwikkeling van het opleidingsaandeel in de werkgelegenheid, is ook gekeken of er sprake is van een trendmatige ontwikkeling van dit opleidingsaandeel op basis van een drietal trendvariabelen: $t, \ln (t)$ en $1 / t$.

Er zijn ook nu in principe geen regressies uitgevoerd wanneer er in een bepaalde beroepsklasse in een bepaald waarnemingsjaar minder dan 500 personen de desbetreffende opleiding hadden. Op deze regel is een aantal uitzonderingen gemaakt voor opleidingen, die in de loop van de onderzochte periode ver boven de 500 werkzame personen uitstegen.

Daarnaast is ook hier telkens gekozen voor de regressie-vergelijking met de hoogste correlatie-coëfficiënt. De prognose van het aandeel van een opleiding in de werkgelegenheid in een beroepsklasse in 1992 vindt opnieuw plaats door de voorspelde waarde van de beroepsspecifieke variabelen voor 1992 in de vergelijking in te vullen of door de vastgestelde trend te extrapoleren naar 1992. Wanneer er geen significante verbanden werden gevonden, is verondersteld dat het aandeel van een opleiding in 1992 gelijk is aan het aandeel van de opleiding in de 
desbetreffende beroepsklasse in 1985. Dit is gedaan, ondat het overgrote deel van de opleidingen (met veel waarnemingen onder de 500) een (vaak verhoudingsgewijs aanzienlijke) toename van het werkgelegenheirsaandeel laten zien. Zou men kiezen voor het gemiddelde aandeel in de periode 1979 - 1985, dan zou het voorspelde aandeel in 1992 ten onrechte lager liggen dan het aandeel in 1985.

Wanneer de voorspelde werkgelegenheidsaandelen worden vermenigvuldigd met de geraamde werkgelegenheid in de desbetreffende beroepsklasse vinden we het aantal werkenden met een bepaalde opleidingsrichting in de beroepsklasse. Sommatie over alle beroepsklassen geeft vervolgens de voorspelling van de totale werkgelegenheid voor academisch geschoolden in de verschillende studierichtingen. Voor de 13 onderscheiden studierichtingen is vervolgens de toename van het aantal werkzame personen uitgedrukt in een percentage van het aantal werkenden in 1985. De gevonden groeipercentages zijn in vergelijking met de gemiddelde groei van de totale werkgelegenheid van ca. $10 \%$ relatief hoog (gemiddeld $27,5 \%$ ). Dit wijst op het optreden van omvangrijke neerwartse verdringingsprocessen. Bij de kwalificatie van het groeipercentage van de werkgelegenheid (E) in een bepaalde studierichting, is uitgegaan van de relatieve positie, die een studierichting inneemt binnen de totale groep universitair geschoolden:

$$
\begin{array}{rll} 
& \dot{E} \geq 40 & \text { erg hoog } \\
30 \leq & \dot{E}<40 & \text { hoog } \\
20 \leq & \dot{E}<30 & \text { gemiddeld } \\
10 \leq & \dot{E}<20 & \text { laag } \\
& \dot{E}<10 & \text { erg laag }
\end{array}
$$

\subsection{Prognose vervangingsuraag}

Zowel voor de 20 onderzochte beroepsklassen als voor de 13 onderschei- 
den studierichtingen binnen het Wetenschappelijk Onderwijs zijn prognoses gemaakt van de verwachte vervangingsvraag tussen 1985 en 1992. In twee subparagrafen zal hierop worden ingegaan.

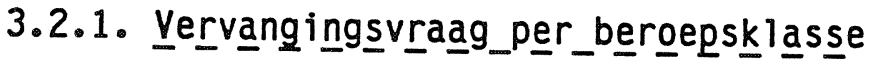

Om een schatting te kunnen maken van de verwachte vervangingsvraag op de arbeidsmarkt, moet eerst een prognose gemaakt worden van de uitstroom van (doorgaans oudere) arbeidskrachten. De uitstroom van arbeidskrachten in een beroepsklasse kan worden geschat door een onderverdeling te maken in verschillende leeftijdscohorten. Op basis van het beschikbare datamateriaal is een opdeling in elf cohorten mogei ijk.

Allereerst is gekeken naar de leeftijdsstructuur van de beroepsbevolking in 1985 en 1992. De prognose van de leeftijdsstructuur in 1992 is afkomstig van het CPB (Op de Beke 1987). Wanneer wordt aangenomen dat er binnen een leeftijdscohort sprake is van een gelijkmatige spreiding van de beroepsbevolking, kan voor ieder leeftijdsjaar worden bepaald hoeveel arbeidskrachten per saldo de beroepsbevolking verlaten of binnentreden. Daartoe vergelijken we het aantal arbeidskrachten met de leeftijd $c$ in 1985 met het aantal arbeidskrachten dat in $1992 \mathrm{c}+7$ jaar oud is. Op basis hiervan kan de jaarlijkse netto uitstroom uit de beroepsbevolking voor de verschillende leeftijdscohorten $\left(g_{85-92}\right.$ VBB $\left._{C}\right)$ worden berekend.

Het ligt echter voor de hand dat de relatieve uitstroom in de verschillende beroepsklassen nogal uiteenloopt. Voor deze beroepsspecifieke component in de uitstroom van arbeid wordt gecorrigeerd door middel van het verschil tussen het jaarlijkse verloop in een leeftijdscohort in een beroepsklasse en het jaarlijkse verloop in de corresponderende leeftijdsgroep in de totale werkzame bevolking in de periode 1979-1985: $\left(g_{79-85}{ }_{W P}{ }_{c}-g_{79-85} V{ }_{c j}\right)$. 
Verondersteld wordt dat de beroepsklassecomponent in het verloop op jaarbasis tussen 1985 en 1992 dezelfde is als in de periode 1979 - 1985. Door bij deze correctiefactor een vergelijking te maken met het verloop onder de werkzame personen in plaats van met de uitstroom uit de beroepsbevolking, wordt vocrkomen dat een conjunctuurcomponent in het verloop (de uitstroom naar de werkloosheid) het beeld verstoort6).

Daar het ons hier gaat om het berekenen van de vervangingsuraag en derhalve alleen on de uitstroom, kijken we alleen naar de cohorten waarin de netto-uitstroom positief is (met name de oudere leeftijdsgroepen). Sommatie over deze leeftijdscohorten geeft de berekende totale vervangingsgraag in de desbetreffende beroepsklasse. Deze totale vervangingsvraag (VBK) is vervolgens telkens uitgedrukt in een percentage van het aantal werkenden in 1985. Uitgaande van een gemiddelde vervangingsuraag van ca $18 \%$ zijn daarbij de volgende kwalificaties gehanteerd:

\begin{tabular}{|c|c|}
\hline VBKK $\geq 25$ & erg hoog \\
\hline $19 \leq V B K K<25$ & hoog \\
\hline $17 \leq \quad \dot{V B K}<19$ & gemiddeld \\
\hline $\begin{aligned} 10 \leq & \dot{V B K}<17 \\
& \dot{V B K}<10\end{aligned}$ & $\begin{array}{l}\text { laag } \\
\text { erg laag }\end{array}$ \\
\hline
\end{tabular}

6) Dit geldt alleen voor zover de relatieve uitstroom naar de werkloosheid niet afwijkt van het gemiddelde. In formulevorm luidt onze berekening als volgt:

(9) $g_{85-92}{ }^{V B K}{ }_{c}=g_{85-92} V B B-\left(g_{79-85} V W P-g_{79-85} V B K\right)$ 


\subsubsection{Vervangsuraag per studierichting}

Bij het traceren van de vervangingsvraag per studierichting kan de in de vorige paragraaf beschreven methodiek niet worden gehanteerd, omdat de beroepsmobiliteit van arbeidskrachten dan het beeld zou vertekenen. Immers, de uitstroom uit een bepaalde beroepsklasse zal voor een deel weer instromen in andere beroepsklassen, waarin arbeidskrachten later in hun loopbaan terecht komen. Daarom moet worden volstaan met het geven van een grove benadering van de te verwachten uitstroom $\left(V_{B K}\right)$. Daarvoor is gekeken naar het aantal arbeidskrachten in een beroepsgroep dat in 198555 jaar of ouder is. Verondersteld wordt dat deze groep tussen 1985 en 1992 in zijn geheel uitstroomt. Waarschijnlijk betekent dit dat het verloop in deze leeftijdscohorten enigszins wordt overschat. Daar staat echter tegenover dat geen rekening gehouden wordt met de uitstroom uit de beroepsbevolking van degenen die in 1985 nog geen 55 jaar oud waren.

Vervolgens is de aldus berekende uitstroom van een beroepsklasse omgerekend naar de verschillende studierichtingen door het verloop te vermenigvuldigen met het aandeel van de afgestudeerden in desbetreffende beroepsklasse in 1985 7). Sommatie over de verschillende beroepsklassen geeft dan het berekende totale verloop en daarmee de geraamde vervangingsvraag per studierichting $\left(V S R_{k}\right)$ :

(10) $V R_{k}=\sum^{m}\left(\phi_{k i} V B_{i}\right)$ $\mathbf{i}=1$

Voor alle 13 studierichtingen is de verwachte vervangingsvraag tussen 1985 en 1992 uitgedrukt in de vorm van een percentage van het aantal

7) Deze aanpak veronderstelt - waarschijnlijk in veel gevallen ten onrechte - dat het aandeel van een studierichting in de oudere leeftijdsgroepen gelijk is aan het aandeel van de studierichting in het totale aantal werkenden in de beroepsklasse. Ook hierdoor kan een vertekening van het beeld, doorgaans in de vorm van een overschatting van het verloop van hoger opgeleiden, optreden. 
werkenden in 1985 (VSR). Daarbij is uitgegaan van de volgende indeling (op basis van een gemiddelde vervangingsvraag van ca. $9 \%$ ):

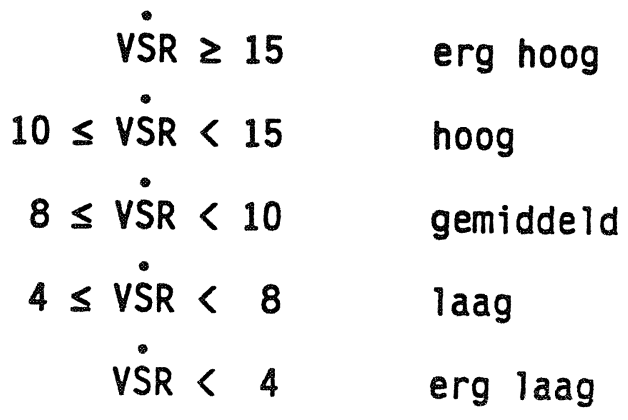

\subsection{Vraag naar schoolverlaters per beroepsklasse}

Voor de verschillende onderzochte beroepsklassen is ook getracht de totale behoefte aan schoolverlaters in beeld te brengen. Deze vraag kan als volgt worden gedefinieerd:

(11) $V S \equiv \Delta E+(U-H)$

waarbij: VS = vraag naar schoolverlaters, $\Delta E=$ mutatie werkgelegenheid, $U=$ uitstroom, $H=$ herintrede

De mutatie van de werkgelegenheid kan worden bepaald door het vergelijken van de voorspelde werkgelegenheid in 1992 met het aantal werkenden in de beroepsklasse in 1985. Voor de berekening van de netto uitstroom $(U-H)$ is in feite dezelfde methodiek gehanteerd als bij het berekenen van de vervangingsvraag in een beroepsklasse. Er is nu echter niet alleen gekeken naar de leeftijdscohorten waarvoor de voorspelde netto-uitstroom positief is, maar ook naar de cohorten war er sprake is van een netto-herintrede. Daarbij wordt verondersteld dat er in de leeftijdsgroepen onder de 30 jaar alleen schoolverlaters in een be-roepsklasse instromen. 
In de beroepsklassen waarin men meestal pas op latere leeftijd instroomt (zoals bv. de beroepsklasse 'beleidvoerende en hogere leidinggevende functies (exclusief openbaar bestuur)'), is de netto-uitstroom veelal negatief, wat kan betekenen dat de vraag naar schoolverlaters in deze beroepsklasse ondanks een toename van de werkgelegenheid, nihil kan zijn. Net als bij de vraagmutaties is ook de vraag naar schoolverlaters uitgedrukt in de vorm van een percentage van het aantal werkzame personen in de desbetreffende beroepsklasse in 1985 (VS). Uitgaande van een gemiddelde van ca. $16 \%$ is daarbij de volgende indeling gemaakt:

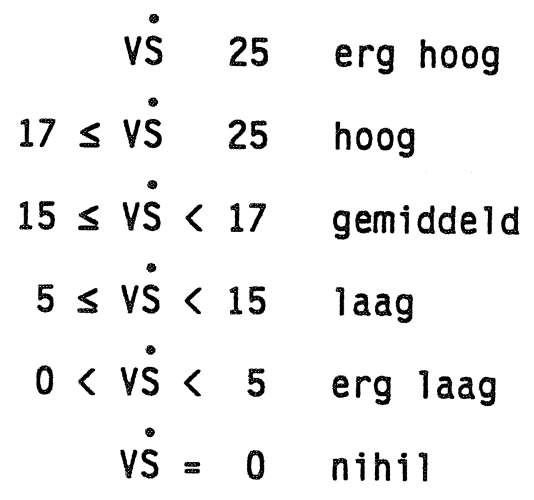

\subsection{Totale vraag naar arbeid}

Voor zowel de beroepsklassen als de studierichtingen binnen het Wetenschappelijk Onderwijs is op basis van de geschatte werkgelegenheidsgroei (de 'uitbreidingsuraag') en de vervangingsvraag de 'totale vraag' berekend. Het gaat hier on de totale vraag naar nieuwe arbeidskra-hten in de desbetreffende beroepsklasse of studierichting voor de periode 1985 - 1992, hetgeen niet verward mag worden met de totale vraag op een bepaald moment. Met dit laatste statische begrip wordt doorgaans gedoeld op de totale werkgelegenheid op een bepaald moment. Ook hier is de totale vraag naar nieuwkomers telkens uitgedrukt in een percentage van het aantal werkenden in 1985 (VN). 
Uitgaande van een gemiddelde totale vraag naar nieuwkomers van ca. $28 \%$, is voor de verschillende beroepsklassen de volgende indeling gemaakt:

$$
\begin{array}{rll}
V \dot{N} & \geq 40 & \text { erg hoog } \\
32 \leq V \dot{N}<40 & \text { hoog } \\
24 \leq V \dot{N}<32 & \text { gemiddeld } \\
18 \leq V \dot{N}<24 & \text { laag } \\
V \dot{N} & <18 & \text { erg laag }
\end{array}
$$

Voor verschillende studierichtingen is bij de indeling uitgegaan van een gemiddelde totale vraag naar nieuwkomers van ca. $36 \%$. Dit leidde tot de volgende indeling:

$$
\begin{array}{rll}
V \dot{N} & \geq 50 & \text { erg hoog } \\
40 \leq V \dot{N}<50 & \text { hoog } \\
30 \leq V \dot{N}<40 & \text { gemiddeld } \\
20 \leq V \dot{N}<30 & \text { laag } \\
V \dot{N}<20 & \text { erg laag }
\end{array}
$$

\subsection{Prognose aantal afgestudeerden}

Om te kunnen komen tot een typering van de verwachte arbeidsmarktsituatie in 1992 voor de verschillende studierichtingen, is het noodzakelijk de hierboven beschreven vraagvoorspellingen te confronteren met een voorspelling van de verwachte instroom van afstuderenden in de periode 1985 - 1992. Op basis van globale CPB-prognoses publiceert de Taakgroep Studentenramingen elk jaar een meer gedetailleerde raming 
van de toekomstige jaarlijkse aantallen afstuderenden in het Wetenramingen $1986-$ I).

Deze prognoses zijn het uitgangspunt geweest voor onze raming van het aantal afstuderenden in de verschillende studierichtingen. Daarbij is gekeken naar de WORSA-prognoses voor de studiejaren 1985 - 1986 tot 1991 - 1992, zowel voor de oude-stijl studies als voor de eerste-fase opleidingen nieuwe stijl in het Wetenschappelijk Onderwijs. De WORSAprognoses zijn door ons op een tweetal punten bewerkt. In de eerste plaats zijn de ramingen van de verschillende studies opgedeeld over de 13 door ons onderscheiden studierichtingen. In de tweede plaats is om de cijfers vergelijkbaar te maken met de vraagprognoses, bij een aantal studierichtingen ook gekeken naar het verwachte aantal afstuderenden aan enkele niet-universitaire opleidingen, die in de Standaard Onderwijs Indeling toch tot het hoogste opleidingsniveau worden gerekend. Het gaat hier om een viertal opleidingen: de Bouwkunst Academie (toegevoegd aan studierichting technisch onderwijs), de Voortgezette Agogische Beroepsopleiding (toegevoegd aan sociaal-culturele wetenschappen), de NIVRA accountancy-opleidingen (toegevoegd aan economische wetenschappen) en de Rijksacademies Beeldende Kunst (toegevoegd aan kunst-onderwijs) 8). Om de vergelijkbaarheid met de vraagontwikkeling te vergemakkelijken is het aantal afstuderenden telkens uitgedrukt in de vorm van een percentage van het aantal werkzame personen in 1985 (A). Daar deze instroompercentages gemiddeld erg hoog liggen, is bij het toekennen van kwalificaties aan deze percentages niet uitgegaan van de gemiddelde instroom, mar van de gemiddelde groei van de totale vraag naar academisch geschoolden van ca $36 \%$. Op deze wijze

8) Data yoor de eerste twee opleidingen zijn afkomstig uit de zogenaamde RHOBOS-voorspellingen van het HBO (Taakgroep Studentenraop basis van extrapolatie van zijn daarentegen door ons bepaald terwijl de cijfers van de gebaseerd op door deze academie verstrekteeldende kunst zijn 
ontstond de volgende indeling:

$$
\begin{array}{rll}
\dot{A} & \geq 60 & \text { erg hoog } \\
40 \leq \dot{A}<60 & \text { hoog } \\
30 \leq \dot{A}<40 & \text { gemiddeld } \\
15 \leq \dot{A}<30 & \text { laag } \\
\dot{A}<15 & \text { erg laag }
\end{array}
$$

\subsection{Typering arbeidsmarktsituatie naar studierichting}

Door een vergelijking te maken tussen de door ons berekende totale vraag naar nieuwe arbeidskrachten met de desbetreffende opleiding in de periode 1985 - 1992 en de verwachte instroom van afstuderenden in hetzelfde tijdvak, is geprobeerd een indicatie te geven van de arbeidsmarktsituatie warin degenen die in 1992 in een bepaalde studierichting afstuderen zullen terechtkomen. We hanteren hiervoor slechts een globale indicator, omdat het ons inziens niet verantwoord is om op basis van de vraag- en aanbodprognoses een ('punt'-) voorspeliing te maken van de verwachte werkloosheid in het prognosejaar. Ten eerste omdat met name de vervangingsvraag-ramingen voor de verschillenden studierichtingen slechts indicatief zijn. Ten tweede ondat onze prognoses van de werkgelegenheidsontwikkeling voor academici waarschijnlijk nog onvoldoende rekening houden met de neerwaartse verdringingsprocessen die ongetwijfeld zullen optreden, wanneer de historisch gezien erg hoge aantallen afstuderenden in de periode 1985 - 1992 hun plek op de arbeidsmarkt proberen te veroveren (zie ook paragraaf 3.1.3).

Desalniettemin is de door ons berekende indicator, het quotiënt van 
de instroom van afstuderenden en de som van de vervangings- en uiteen globale typering van de arbeide 1992 , wel degelijk maatgevend voor de volgende indeling gehanteerd voor (AMI):

$$
\begin{aligned}
& \text { AMI } \leq 0.5 \text { erg goed arbeidsmarktperspectief } \\
& 0,5<A M I \leq 1 \text { goed arbeidsmarktperspectief } \\
& 1<\text { AMI } \leq 2 \text { redelijk arbeidsmarktperspectief } \\
& 2<A M I \leq 4 \text { matig arbeidsmarktperspectief } \\
& 4<A M I \leq 8 \text { slecht arbeidsmarktperspectief } \\
& \text { AMI > } 8 \text { erg slecht arbeidsmarktperspectief. }
\end{aligned}
$$




\section{ARBEIDSMARKTPERSPECTIEVEN BEROEPEN EN STUDIERICHTINGEN}

\subsection{Typering beroepsklassen}

Vanzelfsprekend is de situatie op de arbeidsmarkt op het moment van afstuderen een belangrijke overweging voor een leerling die zijn of haar studiekeuze mede wil afstemmen op de arbeidsmarktperspectieven, die verschillende studierichtingen bieden. Het is daarnaast echter ook belangrijk hoe de arbeidsmarkt zich op langere termijn zal ontwikkelen en welke flexibiliteit men daarbij in de toekomst heeft. Daarom is geprobeerd de verschillende beroepskiassen vanuit meerdere oogpunten te classificeren.

Daarbij is gekeken naar:

- de vraagprognose voor de periode 1985-'92 (zie paragraaf 3.4);

- de conjunctuurgevoeligheid van het beroep (zei paragraaf 2.3);

- de branchespreiding van het beroep (zie paragraaf 2.3);

De branchespreiding kan daarbij, zoals in paragraaf 2.3 reeds werd opgemerkt, gezien worden als een indicator voor de uitwijkmogelijkheden naar andere bedrijfssectoren. Men kan zich afvragen of hier wel echt sprake is van uitwijkmogelijkheden, omdat de werkgelegenheidsontwikkeling in alle bedrijfssectoren warin een beroepsklasse voorkomt reeds in de werkgelegenheidsprognose voor de desbetreffende beroepsklasse is ingecalculeerd. Toch is het wel terecht om te spreken van uitwijkmogelijkheden. Immers, de prognose van de werkgelegenheid in een beroepsklasse is de som van het aantal voorspelde aantal werkenden in de desbetreffende beroepsklasse in de verschillende bedrijfstakken. De indicator voor het bestaan van uitwijkmogelijkheden geeft daarentegen aan of het voor een individuele arbeidskracht in principe mogelijk is naar andere bedrijfstakken uit te wijken. Dit gebeurt op basis van de veronderstelling dat wanneer er arbeidskrachten uit een bepaalde beroepsklasse in een bedrijfstak werkzaam zijn, deze bedrijfstak in principe ook open staat voor de andere arbeidskrachten 
uit de desbetreffende beroepsklasse. Met andere woorden: het gaat hier om een indicator van het uitwijkpotentieel van een beroepsklasse.

Figuur I geeft een overzicht van de wijze waarop de verschillende beroepsklassen op basis van de drie hierboven genoemde invalshoeken zijn geclassificeerd. 


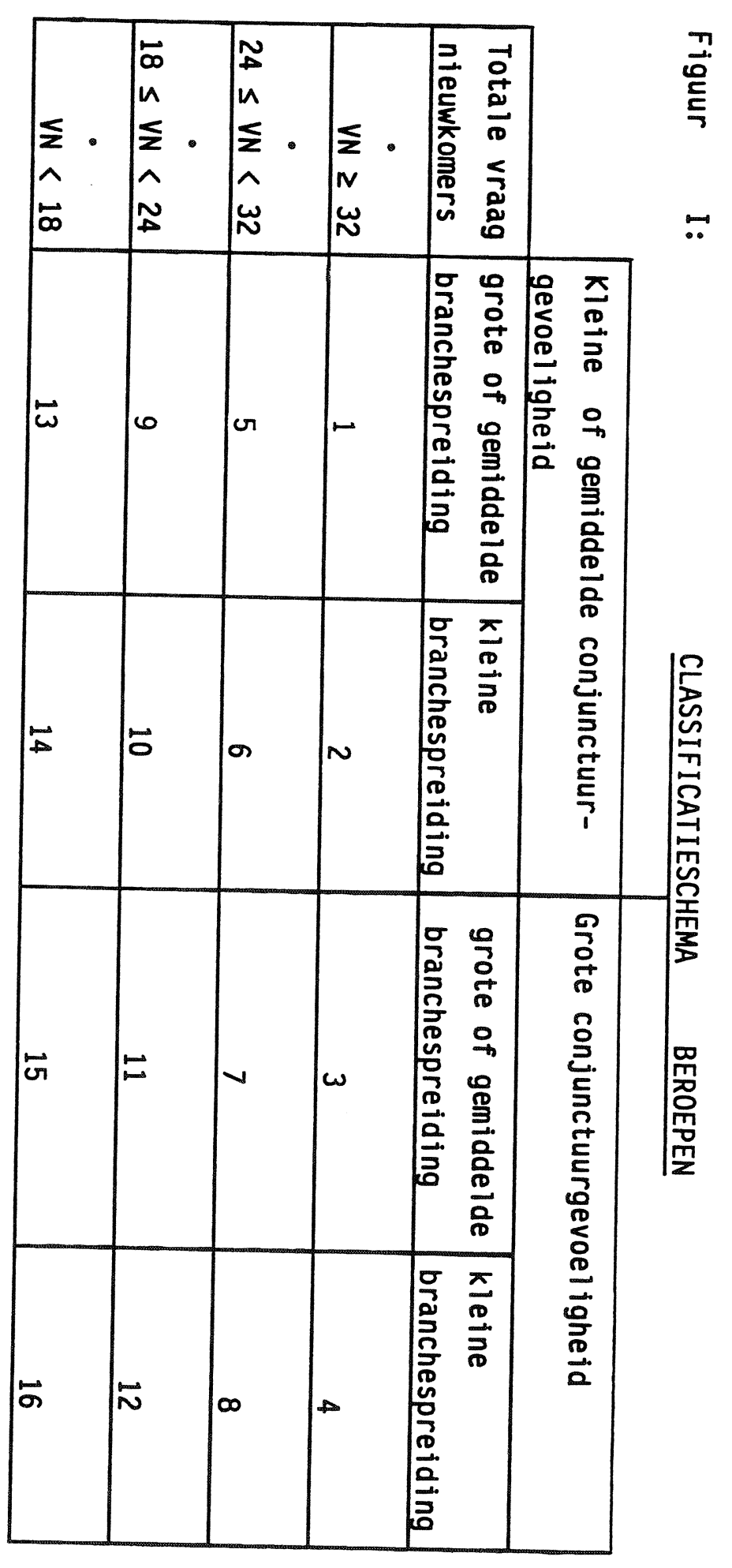


1. Goed arbeidsmarktperspectief, weinig conjunctuurgevoelig, er zijn ook uit-
wijkmogelijkheden.

2. Goed arbeidsmarktperspectief, weinig conjunctuurgevoelig, maar er zijn ook
weinig uitwijkmogelijkheden

3. Goed arbeidsmarktperspectief, maar erg conjunctuurgevoelig. Er zijn echter
uitwijkmogelijkheden.

4. Goed arbeidsmarktperspectief, mar erg conjunctuurgevoelig en weinig uit-
wijkmogelijkheden.

5. Redelijk arbeidsmarktperspectief, weinig conjnunctuurgevoelig en er zijn ook
uitwijkmogelijkheden. ook weinig uitwijkmogelijkheden. 7. Redelijkarbeidsmarktperspectief, maarergconjunctuurgevoelig. Erzijn
echter uitwijkmogelijkheden.

8. Redelijk arbeidsmarktperspectief, mar erg conjunctuurgevoelig en weinig

9. Matigarbeidsmarktperspectief, weinig conjunctuurgevoeligenerzijnook
uitwijkmogelijkheden. 10. Matig arbeidsmarktperspectief, weinig conjunctuurgevoelig, maar er zijn ook
weinig uitwijkmogelijkheden.

11. Matig arbeidsmarktperspectief en bovendien erg conjunctuurgevoelig. Er zijn echter uitwijkmogelijkheden.

12. Matig arbeidsmarktperspectief en bovendien erg conjunctuurgevoelig en weinig 13. Slecht arbeidsmarktperspectief, weinig conjunctuurgevoelig en er zijn ook
uitwijkmogelijkheden. 14. Slecht arbeidsmarktperspectief, weinig conjunctuurgevoelig, maar er zijn ook
weinig uitwijkmogelijkheden. 15. Slecht arbeidsmarktperspectief en bovendien erg conjunctuurgevoelig. Er zijn
echter uitwijkmogelijkheden.

16. Slecht arbeidsmarktperspectief en bovendien erg conjunctuurgevoelig en weinig uitwijkmogelijkheden. 


\subsection{Typering studierichtingen}

Voor de verschillende studierichtingen is getracht naast de typering van de arbeidsmarktsituatie in 1992, ook te kijken naar de beroepenspreiding van de afgestudeerden in de desbetreffende studierichting. Dit laatste is een indicatie voor de uitwijkmogelijkheden naar andere beroepen die men met een bepaalde opleiding heeft. Hier wordt het feit dat afgestudeerden in een bepaald beroep werkzaam zijn, beschouwd als een aanwijzing dat het beroep ook voor andere afgestudeerden in dezelfde studierichting open staat.

Figuur II geeft een overzicht van het classificatie-schema dat op bas is van beide bovengenoemde invalshoeken is opgesteld.

Figuur II: $\quad$ CLASSIFICATIESCHEMA OPLEIDINGEN

\begin{tabular}{|c|c|c|}
\hline $\begin{array}{l}\text { Indicator } \\
\text { Arbeidsmarktsituatie 1992 }\end{array}$ & $\begin{array}{l}\text { Grote of gemiddelde } \\
\text { beroepenspreiding }\end{array}$ & $\begin{array}{l}\text { Kleine } \\
\text { beroepenspreiding }\end{array}$ \\
\hline AMI $\leq 1$ & 1 & 2 \\
$1<$ AMI $\leq 2$ & 3 & 4 \\
$2<$ AMI $\leq 4$ & 5 & 6 \\
$4<$ AMI $\leq 8$ & 7 & 8 \\
AMI >8 & 9 & 10 \\
\hline
\end{tabular}

1 = goed arbeidsmarktperspectief en bovendien enige uitwijkmogelijkheden.

2 = goed arbeidsmarktperspectief, maar weinig uitwijkmogelijkheden

$4=$ redelijk arbeidsmarktperspectief en bovendien enige uitwijkmogelijkheden.

5 = matig arbeidsmarktperspectifef, mar weinig uitwijkmogelijkheden.

6 = matig arbeidsmarktperspectief met enige uitwijkmogelijkheden.

7 = slecht arbeidsmarktperspectief en weinig uitwijkmogelijkheden.

8 = slecht arbeidsmarktperspectief met enige uitwijkmogelijkheden.

9 = erg slecht arbeidsmarktperspectief weinig uitwijkmogelijkheden.

$10=$ erg slecht arbeidsmarktperspectief en weinig uitwijkmogelijkheden. 


\section{BESLUIT}

Zoals in het inleidende hoofdstuk reeds werd opgemerkt, beperkt het beschikbare data-materiaal vooralsnog de mogelijkheden om arbeidsmarktprognoses te verfijnen tot wat vanuit studie- en beroepskeuze oogpunt wenselijk zou zijn. Een eerste aanzet tot een verdergaande desaggregatie van het cijfermateriaal zou gerealiseerd kunnen worden door een systematisch onderzoek naar het bestaan van deelstudies, warin arbeidsmarktdata verzameld zijn voor een bepalde opleidingsrichting of beroepsgroep. Daarbij kan bijvoorbeeld worden gedacht aan de meer systematische NILI-enquêtes onder afgestudeerde Wageningse ingenieurs of de NIRIA-onderzoeken onder technische wetenschappers, maar daarnaast ook aan diverse ad-hoc enquêtes onder afgestudeerden aan een bepaalde faculteit of aan arbeidsmarktonderzoeken m.b.t. specifieke beroepsgroepen (bv. artsen, tandartsen e.d.).

Bij een dergelijk inventariserend onderzoek moet gekeken worden naar de aard en kwaliteit van het data-materiaal en naar de mogelijkheden om de uitkomsten van deze deelstudies in onze arbeidsmarktprognoses te integreren. Een dergelijk onderzoek zou ons inziens moeten worden overwogen bij de verdere ontwikkeling van I SEE.

Op een wat langere termijn zou gestreefd moeten worden naar het creëren van een infrastructuur van waruit periodiek, landelijk uniforme enquêtes onder afgestudeerden in de verschillende studierichtingen kunnen worden gehouden. Op den duur zouden dergelijke enquêtes een belangrijke bijdrage kunnen leveren aan zowel een verdere verfijning van de arbeidsmarktprognoses, als ook aan de kwaliteit van het data-materiaal op basis waarvan prognoses kunnen worden gemaakt. $\mathrm{Er}$ is echter zoals in de inleiding van deze nota ook al werd opgemerkt, wel degelijk een grens aan de mate waarin een verdere desaggregatie van arbeidsmarktprognoses gewenst is. Deze grens wordt gesteld door het criterium dat aparte prognoses voor verschillende studies 
alleen zinvol zijn, wanneer er sprake is van een daadwerkelijk onderscheid tussen twee arbeidsmarktsegmenten. Wanneer gestreefd wordt naar een verdere verfijning van de arbeidsmarktprognoses is verder onderzoek derhalve vereist.

Bij de beroepenprognoses gaat het bovendien niet alleen om het bewerkstelligen van een grotere desaggregatie, mar vooral ook om de verbetering van de clustering van beroepen in beroepsklassen. De CBS-beroepsklassen, die het uitgangspunt waren van onze beroepenprognoses sporen dikwijls niet met de reële beroepsdomeinen waarop men zich bij de studie- en beroepskeuze wil oriënteren. Er is dus niet alleen voor de beroepenmodule, maar ook voor de arbeidsmarktmodule een herclassificatie van de beroepen vereist. $\mathrm{Er}$ is echter wel een verschilpunt met de 'herfundering' (zie Bakkenist, Spits en Co., 1986) van de beroepsdomeinen die m.b.t. de beroepenmodule wordt nagestreefd. Bij deze herfundering gaat het immers in principe om overeenkomsten en verschillen tussen de taken die men in de verschillende beroepen verricht, terwijl vanuit de arbeidsmarktoptiek de afbakening van arbeidsmarktsegmenten centraal zou moeten staan.

Men kan weliswaar zeggen dat als de taken die men in twee verschillende beroepen moet verrichten deels overeenstemmen, beide beroepen tot hetzelfde arbeidsmarktsegment gerekend moeten worden. Wanneer de functietaken echter te breed worden geformuleerd, hoeft dit niet het geval te zijn. Bovendien is de mate waarin de takenpakketten van beroepen of de vakkenpakketten van opleidingen moeten overeenstemmen om van één en hetzelfde arbeidsmarktsegment te kunnen spreken ook afhankelijk van de situatie op de arbeidsmarkt. Wanneer er sprake is van een krappe arbeidsmarkt voor een bepaald beroep zullen arbeidskrachten in aangrenzende beroepen of met een niet geheel ideale opleiding voor het desbetreffende beroep, gemakkelijk tot deze beroepsgroep kunnen toetreden. Bij een ruime arbeidsmarkt (aanbodoverschot) zal de afbakening van het beroepsdomein echter veel stringenter zijn. 
Overwogen moet derhalve worden om ook de arbeidsmarktoptiek te betrek-
ken in het onderzoek naar het herfunderen van zou onderzoek verricht moeten worden naar het mobiliteitspotentieel tussen beroepen en de mobiliteitsmogel ij beroepen. Daarbij zou ook onderzocht velden er bestaan tussen deze inval moeten worden welke spanningsdering. Tevens zou moeten worden shoek en de beroepenkundige herfunnieuwe beroepenindelingen naar de wijze zouden wensen geformuleerd deze CBS-classificatie. 


\section{LITERATUUR}

Bakkenist, Spits en Co. (1986), Onder Loeksresultaten Herfundering Beroepenkundige theorie en methodiek, fase I, 's-Gravenhage.

Beke, J.M.J. op de, (1987), Herziening trendmatig arbeidsaanbod 1985-2000, interne notitie CPB no II.10, 's Gravenhage.

Centraal Planbureau, (1986), Centraal Economisch Plan 1986, Staatsuitgeverij, 's-Gravenhage.

Centraal Planbureau, (1987), Centraal Economisch Plan 1987, Staatsuitgeverij, 's-Gravenhage.

Dijkstra, F.Y.: W.W. Schut (1987), Arbeidsmarkt en academici 1947-1985, Ministerie van Onderwijs en Wetenschappen, directie Toekomstverkenningen, HW/T-verkenningen no. 24, Zoetermeer.

Grip, A. de (1987), Onderwijs en Arbeidsmarkt: Scholingsdiscrepanties, Amsterdam.

Grip, A. de; J.A.M. Heijke en L.A. Vos (1987), Een inventariserend onderzoek Arbeidsmarktmodule I-SEE project, ROA-nota R-1987/1, Maastricht.

Ministerie van Sociale Zaken en Werkgelegenheid (1987), Rapportage Arbeidsmarkt 1987, 's-Gravenhage.

Nederlands Economisch Instituut (1972), Bouwnijuerheid: groei, planning en fluctuatie, deel II: fluctuatie, Rotterdam.

Nederlands Economisch Instituut (1986), Een verkenning van de arbeidsmarkt naar beroep en opleiding, OSA-werkdocument nr. W17, 
's-Gravenhage.

Pere, H.M. (1986), Arbeidsmarktvoorlichting; Een voorstel voor interdisciplinaire opbouw, Centrum voor Beleidsanalyse en Advies,

Taakgroep Studentenramingen (1986-I), Wetenschappelijke Onderwijs Ramingen Studenten Aantallen 1986-2000 (WORSA 1986), 's-Gravenhage.

Taakgroep Studentenramingen (1986-II), Raming Hoger Beroepsonderwijs Studentenaantallen 1986-2000 (RHOBOS 1986), 's-Gravenhage.

Warnken, J. (1986), Zur Entwickelung der "internen" Anpassungsfähigkeit der Berufe bis zum Jahre 2000. Projektionen unter den Annahmen der Wachstumsszenarien der Prognos-Studie, Mitteilungen aus der Arbeitsmarkt- und Berufsforschung, no 1, blz. 119-133. 
BI JLAGEN 


\section{BIJLAGE I: ARBEIDSMARKTDATA STUDIERICHTINGEN}

Bron: ROA/CBS 


\section{OVERZICHT VAN STUDIERICHTINGEN}

Letteren

Theologie

Agrarische Wetenschappen en Huishoudkunde

Wis- en Natuurkunde

Technische Wetenschappen

Medische Opleidingen

Farmacologie

Economische Wetenschappen en Bedrijfskunde (drs.)

Econometrie, Actuariaat en Bedrijfskunde (ir.)

Rechten

Sociaal-Culturele Wetenschappen

Kunstonderwijs

MO-B Akten
SOI-code* Bladzijde

611

3

616

6

621,622 ,

623,629 ,

681

631

$636,638, \quad 14$

639

651

18

652

20

661

22

662 25

666

27

671

30

686

33

606

* Standaard Onderwijs Indeling 1978, Centraal Bureau voor de Statistiek. 


\section{VERKLARING VAN DE GEBRUIKTE TEKENS}

* Gemiddelde op basis van de jaren 1979, 1981, 1983 en 1985.

** Op basis van een vergelijking tussen de jaren 1983 en 1985 ten opzichte van de jaren 1979 en 1981.

$++=$ sterk stijgend

$t=$ stijgend

$0=$ constant

- = dalend

-- = sterk dalend

Voor de hierbij gehanteerde classificatiecriteria zie bijlage

*** Deze ratio geeft het werkloosheidspercentage ten opzichte van het gemiddelde werkloosheidspercentage van academici $(7 \%)$ weer.

**** Deze ratio geeft de verhouding weer tussen de ontwikkeling van werkloosheid vanaf 1978 in de specifieke studie en de totale werkloosheidsontwikkeling 1978 - 1986 in de opleidingssector.

$\star \star \star \star * *$ Het betreft hier het quotiënt van de instroom van afstuderenden en de totale vraag naar nieuwkomers in de periode 1985-1992.

\# Te gering percentage of aantal (zie paragraaf 2.1). 
LETTEREN

Code (s): 611

HISTORISCHE DATA

I. Gemiddeld aantal werkenden 1979 - 1985*:

trend**

- absoluut aantal:

- in \% van het totaal aantal werkenden:

- in \% van het totaal aantal werkenden

14.500 met een universitaire opleiding :

$\begin{array}{ll}0.29 & + \\ 7.0 & 0\end{array}$

II. Belangrijkste beroepsklassen warin men werkzaam is: (gemiddeld percentage $1979-1985^{\star}$ )

1. (13) Leerkrachten

2. (19) Diverse wetenschappelijke

\% trend**

e.a. vakspecialisten

3. (15) Auteurs, journalisten e.d.

4. (39) Diverse administratieve functies

5. (21) Beleidvoerende en hogere leidinggevende functies (exclusief openbaar bestuur)

$67 \quad 0$

$18 \quad 0$

$\#$

III. Gemiddeld aandeel in de werkgelegenheid van de beroepsklasse 1979 - 1985*:

in $\%$ van totaal trend**

1. (13) Leerkrachten

2. (19) Diverse wetenschappelijke e.a. vakspecialisten in beroepsklasse

$\begin{array}{lc}4 & + \\ 3 & + \\ \text { in \% van aantal } & \text { trend** } \\ \text { univ. geschoolden } \\ \text { in beroepsklasse }\end{array}$

1. (13) Leerkrachten

2. (19) Diverse wetenschappelijke 
IV. Werkloosheid (november/december):

- absoluut aantal in 1986: 2.930

- Totaal letteren

- Nederlands

- Duits

- Frans

- Engels

- Wijsbegeerte

- Geschiedenis

- Slavische talen

- Spaans

- Scandinavische talen

- Latijn

- Grieks

- Archeologie

- Algemene taal- en literatuurwetenschappen

\section{INDICATOREN}

\begin{tabular}{|c|c|c|c|}
\hline $\begin{array}{l}\text { \% werkloos- } \\
\text { heid } 1985\end{array}$ & $\operatorname{ratio}_{\star \star \star x} 1$ & $\operatorname{ratio}_{\star \star \star \star \star} 2$ & $\begin{array}{l}\text { trend } \\
\star \star\end{array}$ \\
\hline $\begin{array}{r}15 \\
18 \\
12 \\
10 \\
10 \\
25\end{array}$ & $\begin{array}{l}2.2 \\
2.6 \\
1.7 \\
1.4 \\
1.4 \\
3.6\end{array}$ & $\begin{array}{l}1.5 \\
1.3 \\
1.6 \\
1.0 \\
0.6 \\
1.7 \\
0.4 \\
0.6 \\
1.1 \\
1.0 \\
0.8 \\
0.8\end{array}$ & $\begin{array}{l}++ \\
++ \\
++ \\
++ \\
++ \\
++ \\
++ \\
++ \\
++ \\
++ \\
++ \\
++ \\
++\end{array}$ \\
\hline$n$ & & 0.5 & ++ \\
\hline
\end{tabular}

$\begin{array}{lclc}\text { Beroepenspreiding: } & \text { HG-ratio } & \text { kwalificatie } & \text { trend** } \\ \left.\text { (gemiddelde 1979 }-1985^{*}\right) & 0.53 & \text { gemiddeld } & 0\end{array}$

PROGNOSES

Arbeidsmarktontwikkeling 1985 - 1992:

(in \% werkgelegenheid in 1985)

Werkgel egenheidsontwikkeling

Vervangingsvraag

Totale vraag naar nieuwkomers

Instroom afgestudeerden

Indicator arbeidsmarktsituatie

$\begin{aligned} \underline{\%} & \text { kwalificatie } \\ 13 & \text { laag } \\ \frac{7}{20} & \begin{array}{l}\text { laag } \\ \text { laag }\end{array} \\ 126 & \text { erg hoog } \\ 6.3 & \begin{array}{l}\text { slecht arbeids- } \\ \text { marktperspectief }\end{array}\end{aligned}$




\section{TYPERING}

Slecht arbeidsmarktperspectief met enige uitwijkmogelijkheden. 
THEOLOGIE

Code(s): 616

HISTORISCHE DATA

I. Gemiddeld aantal werkenden 1979 - 1985*:

- absoluut aantal:

- in \% van het totaal aantal werkenden:

- in \% van het totaal aantal werkenden met een universitaire opleiding :

5.900

$\begin{array}{ll}0.12 & + \\ 2.8 & 0\end{array}$

II. Belangrijkste beroepsklassen waarin men werkzaam is:

(gemiddeld percentage 1979 - $1985 *$ )

trend**

1. (14) Bedienaars van de eredienst en

2. (13) Leerkrachten

3. (19) Diverse wetenschappelijke e.a. vakspecialisten

4. (21) Beleidvoerende en hogere leidinggevende functies (excl. openbaar bestuur) \#

III. Gemiddeld aandeel in de werkgelegenheid van de beroepsklasse 1979 - 1985*:

in $\%$ van totaal trend** aantal werkenden in beroepsklasse

1. (14) Bedienaars van de eredienst

2. (13) Leerkrachten

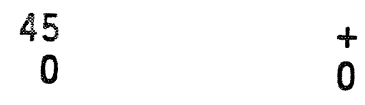

in \% van aantal trend** univ. geschoolden

in beroepsklasse

1. (14) Bedienaars van de eredienst

2. (13) Leerkrachten

93

0

20 
IV. Werkloosheid (november/december):

- absoluut aantal in 1986: 218

\begin{tabular}{|c|c|c|c|}
\hline & $\begin{array}{l}\% \text { werkloos- } \\
\text { heid } 1985 \\
\end{array}$ & $\begin{array}{l}\text { ratio } 1 \\
\star \star \star \star\end{array}$ & $\begin{array}{l}\text { trend } \\
\star \star\end{array}$ \\
\hline - totaal theologie & 3 & 0.4 & \\
\hline
\end{tabular}

INDICATOREN

\begin{tabular}{|c|c|c|c|}
\hline & HG-ratio & kwalificatie & trend** \\
\hline $\begin{array}{l}\text { Geroepenspreiding: } \\
\text { (gemiddelde } 1979-1985^{\star} \text { ) }\end{array}$ & 0.49 & gemiddeld & + \\
\hline
\end{tabular}

PROGNOSES

Arbeidsmarktontwikkeling 1985 - 1992:

(in \% werkgelegenheid in 1985)

Werkgelegenheidsontwikkeling

Vervangingsvraag

Totale vraag naar nieuwkomers

Instroom afgestudeerden

Indicator arbeidsmarktsituatie

voor afgestudeerden in 1992 *****:

$\begin{aligned} \underline{\%} & \text { kwalificatie } \\ 5 & \text { erg laag } \\ \frac{27}{32} & \begin{array}{l}\text { erg hoog } \\ \text { gemiddeld }\end{array} \\ 11 & \text { erg laag } \\ 0.3 & \begin{array}{l}\text { erg goed arbeids- } \\ \text { marktperspectief }\end{array}\end{aligned}$

TYPERING

Goed arbeidsmarktperspectief en bovendien enige uitwijkmogelijkheden. 
AGRARISCHE WETENSCHAPPEN EN HUISHOUDKUNDE

Code(s): 621, 622, 623, 629, 681

\section{HISTORISCHE DATA}

trend**

I. Gemiddeld aantal werkenden $1979-1985 *$ :

- absoluut aantal:

- in \% van het totaal aantal werkenden:

- in \% van het totaal aantal werkenden met een universitaire opleiding :

4.800

$\begin{aligned} & 0.09 \\ & 2.2\end{aligned}++$

II. Belangrijkste beroepsklassen warin men werkzaam is:

(gemiddeld percentage $1979-1985 *$ )

1. (5) Biologen, biochemici, landbouwkundigen

2. (13) Leerkrachten

3. (2) Architecten, ingenieurs en verwante technici

4. (21) Beleidvoerende en hogere leidinggevende

\% $\quad$ trend**

5. (19) functies (excl. openbaar bestuur) Diverse wetenschappelijke e.a. vakspe-

6. (31) Uitvoerende hoofdambtenaren

7. (33) Bankemployés, lokettisten e.d.

8. (60) Bedrijfsleiders land- en tuinbouw e.d.

9. (9) Economen

10. (39) Diverse administratieve functies

11. (45) Toezichthoudend- en leidinggevend

12. (20) Beleidvoerende en hogere leidinggevende functies bij openbaar bestuur 
III. Gemiddeld aandeel in de werkgelegenheid van de beroepsklasse 1979 - 1985*:

\section{in \% van totaal aantal werkenden \\ trend** in beroepsklasse}

1. (5) Biologen, biochemici, landbouwkundigen en verwante

2. (13) Leerkrachten

3. (2) Architecten, ingenieurs en verwante technici

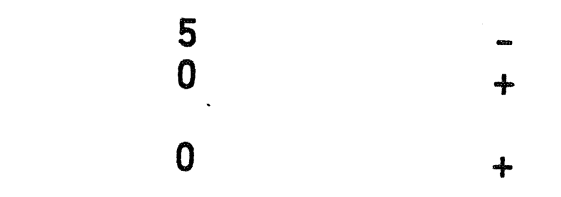

in $\%$ van aantal trend** univ. geschoolden in beroepsklasse

1. (5) Biologen, biochemici, landbouwkundigen en verwante vakspecialisten

2. (13) Leerkrachten

3. (2) Architecten, ingenieurs en verwante technici

IV. Werkloosheid (november/december):

- absoluut aantal in 1986: 600

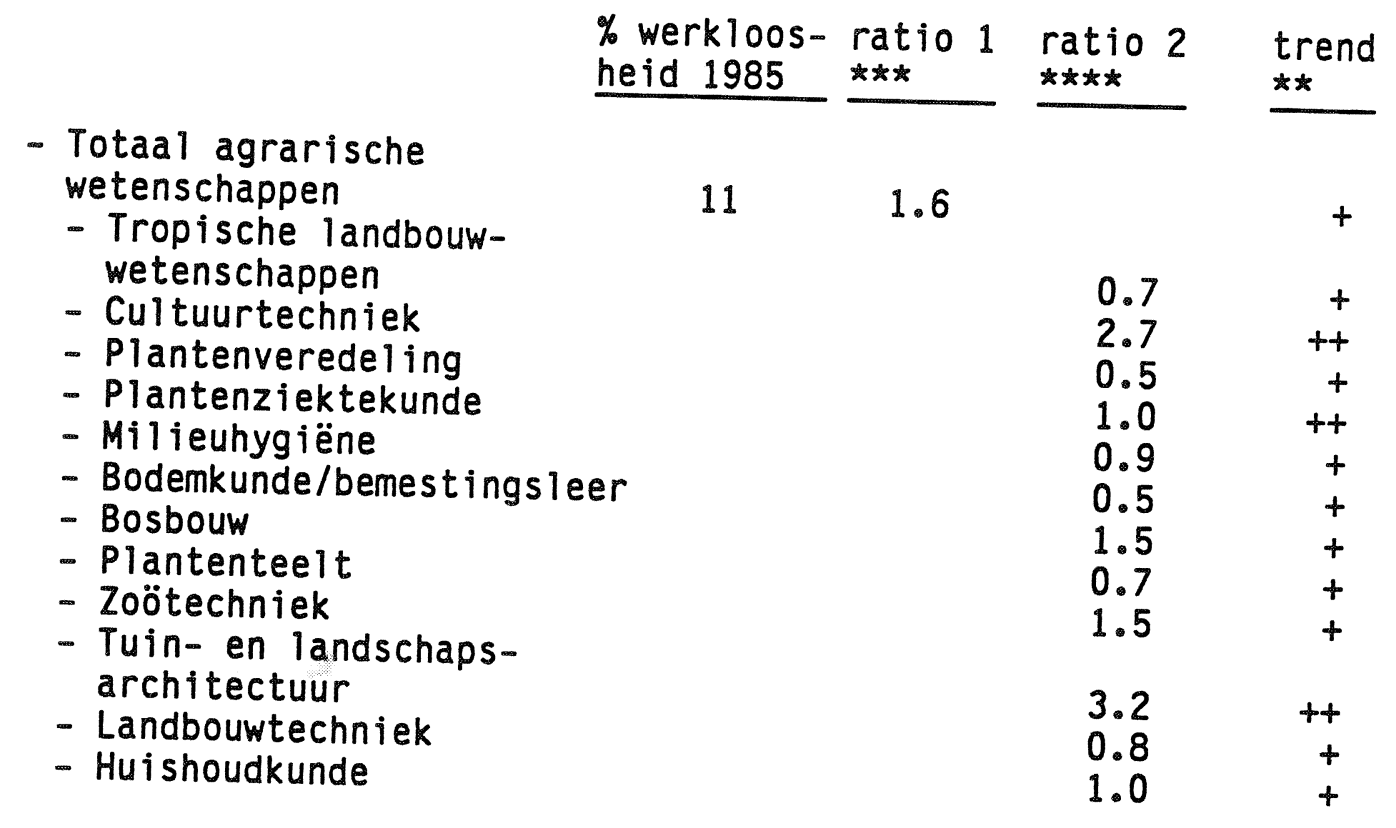




\section{INDICATOREN}

\section{Beroepenspreiding:}

\section{HG-ratio kwalificatie trend**}

(gemiddelde 1979 - 1985*)

0.82 groot

\section{PROGNOSES}

Arbeidsmarktontwikkeling 1985 - 1992:

(in \% werkgelegenheid in 1985)

$\begin{array}{lrl}\text { Werkgelegenheidsontwikkeling } & \underline{\%} & \text { kwalificatie } \\ \text { Vervangingsvraag } & 23 & \text { gemiddeld } \\ \text { Totale vraag naar nieuwkomers } & \frac{8}{31} & \begin{array}{l}\text { gemiddeld } \\ \text { gemiddeld }\end{array} \\ \begin{array}{l}\text { Instroom afgestudeerden } \\ \begin{array}{l}\text { Indicator arbeidsmarktsituatie } \\ \text { voor afgestudeerden in 1992 *****: }\end{array}\end{array} & 119 & \text { erg hoog } \\ & 3.8 & \begin{array}{l}\text { matig arbeids- } \\ \text { marktperspectief }\end{array}\end{array}$

TYPERING

Matig arbeidsmarktperspectief met enige uitwijkmogelijkheden. 


\section{WIS- EN NATUURKUNDE}

Code(s): 631

\section{HISTORISCHE DATA}

trend**

I. Gemiddeld aantal werkenden 1979 - 1985*:

- absoluut aantal:

- in \% van het totaal aantal werkenden:

21.100

- in \% van het totaal aantal werkenden met een universitaire opleiding :

$0.42 \quad 0$

10.3

II. Belangrijkste beroepsklassen waarin men werkzaam is: (gemiddeld percentage 1979 - 1985 *)

\% $\quad$ trend**

1. (13) Leerkrachten

2. (1) Schei-, natuurkundigen en verwante

technici

3. (5) Biologen, biochemici, landbouwkundigen

4. (8) en verwante vakspecialisten

4. (8) Statistici, wiskundigen, systeemanalisten en verwante vakspecialisten

5. (2) Architecten, ingenieurs en verwante technici

6. (19) Diverse wetenschappelijke e.a. vakspecialisten

7. (21) Beleidvoerende en hogere leidingge-

33

20

14

8

vende functies (excl. openbaar bestuur)

8. (39) Diverse administratieve functies
6

6

\section{0}

5 
III. Gemiddeld aandeel in de werkgelegenheid van de beroepsklasse 1979 - 1985*:

\section{in \% van totaal aantal werkenden in beroepsklasse}

trend**

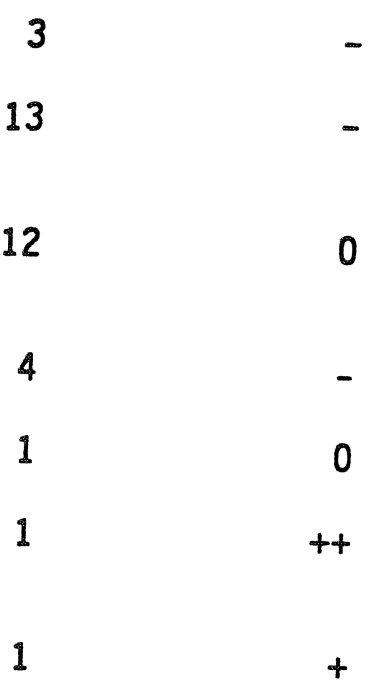

in \% van aantal trend** univ. geschoolden in beroepsklasse

15

79

0

53

36 vakspecialisten

5. (2) Architecten, ingenieurs en verwante technici

6. (19) Diverse wetenschappelijke e.a. vakspecialisten

7. (21) Beleidvoerende en hogere leidinggevende functies (exc1. openbaar bestuur)

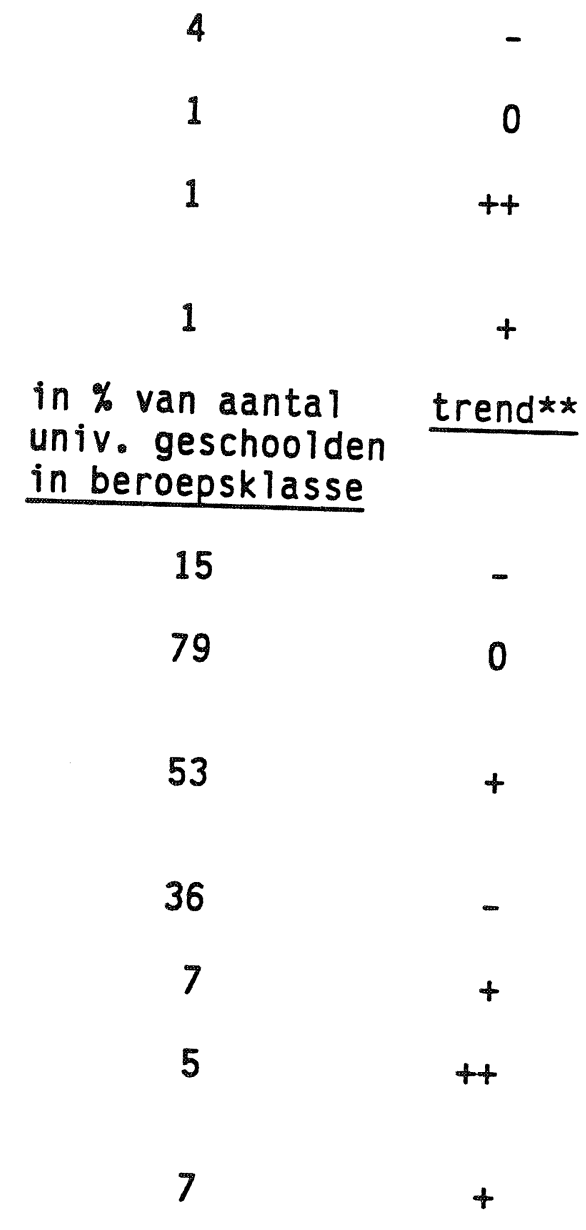


IV. Werkloosheid (november/december):

- absoluut aantal in 1986: 2.019

\% werkloos- ratio 1 ratio 2 trend

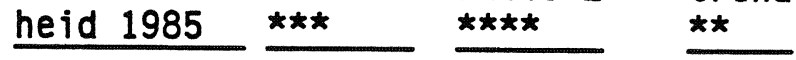

- Totaal wis- en natuurkunde $10 \quad 1.3$

- Wiskunde (drs.)

- Natuurkunde

- Biologie

- Scheikunde (drs.)

0.6

20

2.8

0.9

- Sterrenkunde

0.5

1.2

+
+
++
++
+
+

INDICATOREN

HG-ratio kwalificatie trend**

Beroepenspreiding:

(gemiddelde $1979-1985^{*}$ ) $0.81 \quad$ groot

PROGNOSES

Arbeidsmarktontwikkeling 1985 - 1992:

(in \% werkgelegenheid in 1985)

\% kwalificatie

Werkgelegenheidsontwikkeling

Vervangingsvraag

24 gemiddeld

Totale vraag naar nieuwkomers

7 laag

$\overline{31} \quad$ gemiddeld

Instroom afgestudeerden

79

erg hoog

Indicator arbeidsmarktsituatie

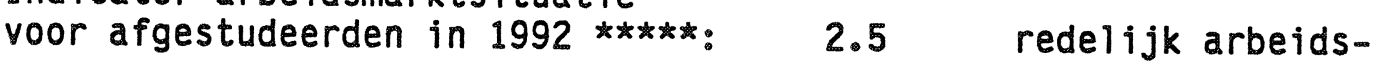
marktperspectief

\section{TYPERING}

Matig arbeidsmarktperspectief me, enige uitwijkmogelijkheden. 


\section{TECHNISCHE WETENSCHAPPEN}

$\operatorname{Code}(s): 636,638,639$

\section{HISTORISCHE DATA}

trend**

I. Gemiddeld aantal werkenden 1979 - 1985*:

- absoluut aantal:

32.500

- in \% van het totaal aantal werkenden:

- in \% van het totaal aantal werkender met een universitaire opleiding :

0

II. Belangrijkste beroepsklassen warin men werkzaam is: (gemiddeld percentage $1979-1985 *$ )

\% trend**

1. (2) Architecten, ingenieurs en verwante technici

2. (21) Beleidvoerende en hogere leidinggevende functies (excl. openbaar bestuur)

3. (13) Leerkrachten

4. (8) Statistici, wiskundigen, systeemanalisten en verwante vakspecialisten

5. (19) Diverse wetenschappelijke e.a. vakspecialisten

6. (1) Schei-, natuurkundigen en verwante technici

7. (70) Toezichthoudend- leidinggevend produktiepersoneel

8. (31) Uitvoerende hoofdambtenaren 
III. Gemiddeld aandeel in de werkgelegenheid van de beroepsklasse 1979 - 1985*:

\section{in $\%$ van totaal trend** aantal werkenden in beroepsklasse}

1. (2) Architecten, ingenieurs en verwante technici

10

$+$

2. (21) Beleidvoerende en hogere leidinggevende functies (excl. openbaar bestuur)

3. (13) Leerkrachten

4. (8) Statistici, wiskundigen, systeemanalisten en verwante vakspecialisten

$\begin{array}{lll} & 10 & + \\ & 3 & 0 \\ 1 & 0 \\ & & +\end{array}$

in $\%$ van aantal trend** univ. geschoolden in beroepsklasse

1. (2) Architecten, ingenieurs en verwante technici

81

2. (21) Beleidvoerende en hogere leidinggevende functies (excl. openbaar bestuur)

3. (13) Leerkrachten

4. (8) Statistici, wiskundigen, systeemanalisten en verwante vakspecialisten 
IV. Werkloosheid (november/december):

- absoluut aantal in 1986: 1.302

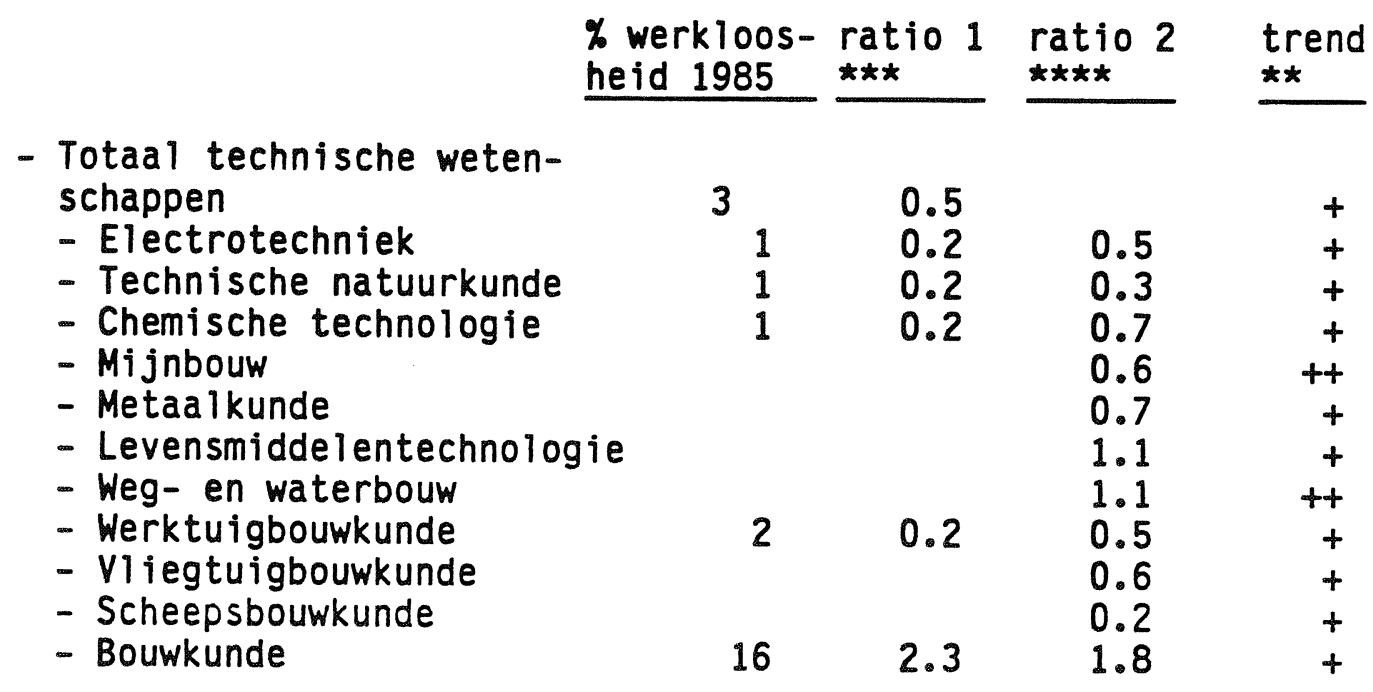

INDICATOREN

HG-ratio kwalificatie trend**

Beroepenspreiding:

(gemiddelde $1979-1985^{*}$ ) 0.68 gemiddeld +

\section{PROGNOSES}

Arbeidsmarktontwikkeling 1985 - 1992:

(in \% werkgelegenheid in 1985)

\% kwalificatie

Werkge legenheidsontwikkeling

Vervangingsvraag

46 erg hoog

Totale vraag naar nieuwkomers

10 hoog

$\overline{55}$ erg hoog

Instroom afgestudeerden

$47 \quad$ hoog

Indicator arbeidsmarktsituatie

voor afgestudeerden in 1992 *****:

0.9 goed arbeidsmarktperspectief 
TYPERING

Goed arbeidsmarktperspectief en bovendien enige uitwijkmogelijk-
heden. 


\section{MEDISCHE OPLEIDINGEN}

Code (s): 651

\section{HISTORISCHE DATA}

trend**

1. Gemiddeld aantal werkenden 1979 - 1985*:

- absoluut aantal:

- in \% van het totaal aantal werkenden:

- in \% van het totaal aantal werkenden met een universitaire opleiding :

32.700

$\begin{array}{cc}0.65 & + \\ 15.8 & 0\end{array}$

11. Belangrijkste beroepsklassen waarin men werkzaam is: (gemiddeld percentage $1979-1985 *$ )

\% trend*t

1. (6) Genees- en tandheelkundigen, dierenartsen, verplegenden en verwante vakspecialisten

2. (13) Leerkrachten

3. (5) Biologen, biochemici, landbouwkundigen en verwante vakspecialisten

4. (21) Beleidvoerende en hogere leidinggevende functies (excl. openbaar bestuur)

5. (19) Diverse wetenschappelijke e.a. vakspecialisten

III. Gemiddeld aandeel in de werkgelegenheid van de beroepsklasse 1979 - 1985*:

in $\%$ van totaal trend**
aantal werkenden
in beroepsklasse

1. (6) Genees - en tandheelkundigen, dierenartsen, verplegenden en verwante vakspecialisten

1. (6) Genees- en tandheelkundigen, dierenartsen, verplegenden en verwante vakspecialisten 
IV. Werkloosheid (november/december):

- absoluut aantal in 1986: 2.186

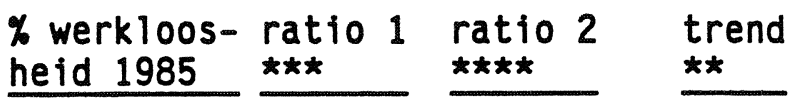

- Totaal medische opleidingen

- Geneeskunde

- Tandheelkunde

- Diergeneeskunde

$\begin{array}{rrrr}6 & 0.9 & & ++ \\ 7 & 1.0 & 1.0 & ++ \\ 9 & 1.3 & 7.5 & ++ \\ 4 & 0.5 & 0.3 & +\end{array}$

INDICATOREN

$\underline{\text { HG-ratio }} \underline{\text { kwalificatie trend** }}$

Beroepenspreiding:

(gemiddelde $1979-1985^{\star}$ ) $0.22 \quad$ klein

PROGNOSES

Arbeidsmarktontwikkeling 1985 - 1992:

(in \% werkgelegenheid in 1985)

Werkgelegenheidsontwikkel ing

Vervangingsuraag

Totale vraag naar nieuwkomers

\% kwalificatie

Instroom afgestudeerden

$16 \quad$ laag

$\frac{5}{21} \quad$ laag

Instroom afgestudeerden

45 hoog

Indicator arbeidsmarktsituatie

voor afgestudeerden in 1992 *k***:

2.2 matig arbeids-

marktperspectief

\section{TYPERING}

Matig arbeidsmarktperspectief en weinig uitwijkmogelijkheden. 


\section{FARMACOLOGIE}

Code (s): 652

\section{HISTORISCHE DATA}

trend**

1. Gemiddeld aantal werkenden 1979 - 1985*:

- absoluut aantal:

- in \% van het totaal aantal werkenden:

- in \% van het totaal aantal werkenden met een universitaire opleiding :

2.000

$\begin{array}{ll}0.04 & + \\ 1.0 & 0\end{array}$

11. Belangrijkste beroepsklassen warin men werkzaam is:

(gemiddeld percentage 1979 - $1985 *$ )

$\underline{\text { trend** }}$

1. (6) Genees - en tandheelkundigen, dierenartsen, verplegenden en verwante vakspecialisten

2. (5) Biologen, biochemici, landbouwkundigen

3. (13) Leerkrachten en verwante vakspecialisten

4. (21) Beleidvoerende en hogere leidinggevende functies (excl. openbaar bestuur)

5. (19) Diverse wetenschappelijke e.a. vakspecialisten

6. (67) Dienstplichtige militairen

III. Gemiddeld aandeel in de werkgelegenheid van de beroepsklasse 1979 - 1985*:

\section{in $\%$ van totaal trend** aantal werkenden in beroepsklasse}

1. (6) Genees - en tandheelkundigen, dierenartsen, verplegenden en verwante vakspecialisten

1

in \% van aantal univ. geschoolden in beroepsklasse

trend**

1. (6) Genees - en tandheelkundigen, dierenartsen, verplegenden en verwante vakspecialisten 
IV. Werkloosheid (november/december):

- absoluut aantal in 1986: 80

\begin{tabular}{|c|c|c|c|}
\hline & $\begin{array}{l}\text { \% werkloos- } \\
\text { heid } 1985 \\
\end{array}$ & $\begin{array}{l}\text { ratio } 1 \\
\star \star \star \star \\
\end{array}$ & $\begin{array}{l}\text { trend } \\
\star \star\end{array}$ \\
\hline - Totaal farmacologie & 4 & 0.6 & \\
\hline
\end{tabular}

\section{INDICATOREN}

$\begin{array}{lrrr} & \text { HG-ratio } & \text { kwalificatie } & \text { trend** } \\ \begin{array}{l}\text { Beroepenspreiding: } \\ \left.\text { (gemiddelde } 1979-1985^{*}\right)\end{array} & 0.51 & \text { gemiddeld } & +\end{array}$

PROGNOSES

Arbeidsmarktontwikkeling 1985 - 1992:

(in \% werkgelegenheid in 1985)

Werkgel egenheidsontwikkeling

Vervangingsvraag

Totale vraag naar nieuwkomers

Instroom afgestudeerden

Indicator arbeidsmarktsituatie voor afgestudeerden in $1992 \star \star \star \star \star * *$ :

$\begin{aligned} \underline{\%} & \text { kwalificatie } \\ 15 & \text { laag } \\ \frac{5}{21} & \text { laag } \\ 137 & \text { laag } \\ & \text { erg hoog } \\ 6.7 & \text { slecht arbeids- } \\ & \text { marktperspectief }\end{aligned}$

TYPERING

Slecht arbeidsmarktperspectief met enige uitwijkmogelijkheden. 
ECONOMISCHE WETENSCHAPPEN EN BEDRIJFSKUNDE (DRS.)

Code(s): 661

\section{HISTORISCHE DATA}

trend**

1. Gemiddeld aantal werkenden 1979 - 1985*:

- absoluut aantal:

- in \% van het totaal aantal werkenden:

- in \% van het totaal aantal werkenden met een universitaire opleiding :

20.500

$\begin{array}{ll}0.41 & + \\ 9.9 & 0\end{array}$

11. Belangrijkste beroepsklassen waarin men werkzaam is: (gemiddeld percentage 1979 - $1985 *$ )

1. (9) Economen

2. (21) Beleidvoerende en hogere leidinggevende functies (excl. openbaar bestuur)

3. (11) Accountants

4. (13) Leerkrachten

5. (33) Bankemployés, lokettisten e.d.

6. (2) Architecten, ingenieurs en verwante technici

7. (31) Uitvoerende hoofdambtenaren

8. (40) Directeuren en bedrijfsleiders groothandel

9. (8) Statistici, wiskundigen, systeemanalisten en verwante vakspecialisten

10. (19) Diverse wetenschappelijke e.a. vakspecialisten

11. (39) Diverse administratieve functies
\% trend*t

21

$21+$

19

12

5

0

$+$

\section{$\#$}

\#

$\#$

$\#$ 
III. Gemiddeld aandeel in de werkgelegenheid van de beroepsklasse 1979 - 1985*:

\section{in $\%$ van totaal trend** aantal werkenden in beroepsklasse}

1. (9) Economen

2. (21) Beleidvoerende en hogere leidinggevende functies (excl. openbaar bestuur)

3. (11) Accountants

4. (13) Leerkrachten

5. (33) Bankemployés, lokettisten e.d.
32

$\begin{array}{rr}3 & 0 \\ 30 & + \\ 1 & 0 \\ 1 & +\end{array}$

$+$

$+$

in \% van aantal trend** univ. geschoolden in beroepsklasse

1. (9) Economen

2. (21) Beleidvoerende en hogere

76 3. (11) Accountants

3. (11) Accountants

5. (33) Bankemployés, lokettisten e.d.

26

88

6

46

0

0

$\overline{0}$

IV. Werkloosheid (november/december):

- absoluut aantal in 1986: 601

\begin{tabular}{|c|c|c|c|c|}
\hline & $\begin{array}{l}\% \text { werkloos- } \\
\text { heid } 1985 \\
\end{array}$ & $\begin{array}{l}\text { ratio } 1 \\
\star \star \star * \\
\end{array}$ & $\begin{array}{l}\text { ratio } 2 \\
\pm x \pm x \\
\end{array}$ & $\begin{array}{l}\text { trend } \\
\star \star\end{array}$ \\
\hline $\begin{array}{l}\text { Totaal economische weten- } \\
\text { schappen } \\
\text { - Algemene economie } \\
\text { - Bedrijfseconomie } \\
\text { - Economische sociologie } \\
\text { - Fiscale economie } \\
\text { - Accountancy }\end{array}$ & - & 0.4 & $\begin{array}{l}1.0 \\
1.2 \\
0.6 \\
2.0 \\
0.5\end{array}$ & $\begin{array}{r}+ \\
++ \\
+ \\
+ \\
++ \\
+\end{array}$ \\
\hline
\end{tabular}


INDICATOREN

HG-ratio kwalificatie trend**

Beroepenspreiding:

(gemiddelde $1979^{-1985^{*}}$ ) $0.86 \quad$ groot 0

\section{PROGNOSES}

Arbeidsmarktontwikkeling 1985 - 1992:

(in \% werkgelegenheid in 1985)

$\begin{array}{lcl}\text { Werkgelegenheidsontwikkeling } & \underline{\%} & \text { kwalificatie } \\ \begin{array}{l}\text { Vervangingsvraag } \\ \text { Totale vraag naar nieuwkomers }\end{array} & 22 & \begin{array}{l}\text { gemiddeld } \\ \text { hoog } \\ \text { gemiddeld }\end{array} \\ \begin{array}{l}\text { Instroom afgestudeerden } \\ \begin{array}{l}\text { Indicator arbeidsmarktsituatie } \\ \text { voor afgestudeerden in 1992 } \star \star \star \star \star:\end{array}\end{array} & 97 & \text { erg hoog } \\ & 2.7 & \text { matig arbeids- } \\ & & \text { marktperspectief }\end{array}$

TYPERING

Matig arbeidsmarktperspectief met enige uitwijkmogelijkheden. 
ECONOMETRIE, ACTUARIAAT EN BEDRIJFSKUNDE (IR.)

Code(s): 662

HISTORISCHE DATA

I. Gemiddeld aantal werkenden 1979 - 1985*:

trend**

- absoluut aantal:

- in \% van het totaal aantal werkenden:

- in \% van het totaal aantal werkenden

1.800 met een universitaire opleiding :

$\begin{array}{ll}0.04 & ++ \\ 0.8 & ++\end{array}$

II. Belangrijkste beroepsklassen waarin men werkzaam is: (gemiddeld percentage $1979-1985^{\star}$ )

1. (9) Economen

2. (8) Statistici, wiskundigen, systeemanalisten

3. (2) en verwante vakspecialisten

3. (2) Architecten, ingenieurs en verwante vak-
specialisten

4. (21) Beleidvoerende en hogere leidinggevende

5. (13) Luncties (excl. openbaar bestuur)

6. (19) Diverse wetenschappelijke e.a. vak-

7. (39) Specialisten

7. (39) Diverse administratieve functies

8. (33) Bankemployés, lokettisten e.d.
9. (6) Genees- en tandheelkundigen, dierenartsen, verplegenden en verwante vakspecialisten \#

IV. Werkloosheid (november/december):

- absoluut aantal in 1986: 64

- Totaal econometrie en

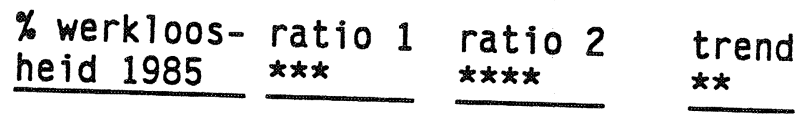
actuariaat en bedrijfskunde (ir.)

- Bedrijfskunde (ir.)

30.4 
INDICATOREN

HG-ratio kwalificatie trend**

Beroepenspreiding:

(gemiddelde $1979-1985^{*}$ ) $\quad 0.80 \quad$ groot

\section{PROGNOSES}

Arbeidsmarktontwikkeling 1985 - 1992:

(in \% werkgelegenheid in 1985)

$\begin{array}{lcl}\text { Werkgelegenheidsontwikkeling } & \underline{\%} & \text { kwalificatie } \\ \begin{array}{l}\text { Vervangingsvraag } \\ \text { Totale vraag naar nieuwkomers }\end{array} & 62 & \begin{array}{l}\text { erg hoog } \\ \text { hoog } \\ \text { erg hoog }\end{array} \\ \begin{array}{l}\text { Instroom afgestudeerden } \\ \frac{10}{72}\end{array} & 108 & \text { erg hoog } \\ \begin{array}{l}\text { Indicator arbeidsmarktsituatie } \\ \text { voor afgestudeerden in 1992 *****: }\end{array} & 1.5 & \begin{array}{l}\text { redelijk arbeids- } \\ \text { marktperspectief }\end{array}\end{array}$

TYPERING

Redelijk arbeidsmarktperspectief en bovendien enige uitwijk-
mogelijkheden. 


\section{RECHTEN}

Code (s): 666

\section{HISTORISCHE DATA}

I. Gemiddeld aantal werkenden 1979 - 1985*:

trend**

- absoluut aantal:

- in \% van het totaal aantal werkenden:

- in $\%$ van het totaal aantal werkenden

24.100 met een universitaire opleiding :

$0.48+$
$11.6+$

II. Belangrijkste beroepsklassen warin men werkzaam is: (gemiddeld percentage $1979-1985^{\star}$ )

1. (12) Juristen

2. (21) Beleidvoerende en hogere leidinggevende

\% $\quad$ trend**

functies (excl. openbaar bestuur)

3. (31) Uitvoerende hoofdambtenaren

4. (13) Leerkrachten 5. (19) Diverse wetenschappelijke e.a. vak-
specialisten

6. (39) Diverse administratieve functies 530

$10 \quad 0$

9

8. (33) Bankemployés, lokettisten e.d.

9. (11) Accountants 10. (32) Secretaressen, typisten en ponstypisten
e.d.

III. Gemiddeld aandeel in de werkgelegenheid van de beroepsklasse 1979 - 1985*:

\section{in \% van totaal trend** aantal werkenden in beroepsklasse}

1. (12) Juristen

2. (21) Beleidvoerencie en hogere

81

0

leidinggevende functies

(excl. openbaar bestuur)

3. (31) Uitvoerende hoofdambtenaren

4. (13) Leerkrachten

$\begin{array}{rr}2 & 0 \\ 11 & + \\ 1 & +\end{array}$




\section{in $\%$ van aantal trend** univ. geschoolden \\ in beroepsklasse}
1. (12) Juristen
2. (21) Beleidvoerencic en hogere leidinggevende functies (excl. openbaar bestuur)

3. (31) Uitvoerende hoofdambtenaren

4. (13) Leerkrachten

IV. Werkloosheid (november/december):

- absoluut aantal in 1986: 1.692
97

0

14

$\begin{array}{rr}43 & 0 \\ 3 & 0\end{array}$

- Totaal rechten

- Nederlands recht

- Bedrijfsrecht

- Privaatrecht

- Publiekrecht

- Strafrecht

- Fiscaal juridisch

- Notariaat

- Vrije jurische richting

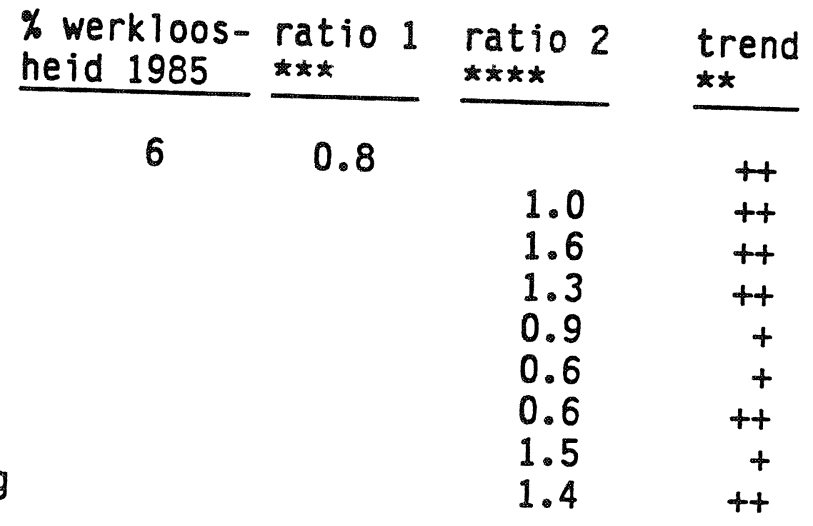

\section{INDICATOREN}

\section{$\underline{\text { HG-ratio }} \underline{\text { kwalificatie trend** }}$}

Beroepenspreiding:

(gemiddelde 1979 - 1985*)

$0.70 \quad$ gemiddeld

0 


\section{PROGNOSES}

Arbeidsmarktontwikkeling 1985 - 1992:

(in \% werkgelegenheid in 1985)

\begin{tabular}{|c|c|c|}
\hline & $\underline{q}$ & kwalificatie \\
\hline $\begin{array}{l}\text { Werkge legenheidsontwikkeling } \\
\text { Vervangingsvraag } \\
\text { Totale vraag naar nieuwkomers }\end{array}$ & $\begin{array}{l}31 \\
\frac{12}{43}\end{array}$ & $\begin{array}{l}\text { hoog } \\
\text { hoog } \\
\text { hoog }\end{array}$ \\
\hline Instroom afgestudeerden & 96 & erg hoog \\
\hline $\begin{array}{l}\text { Indicator arbeidsmarktsituatie } \\
\text { voor afgestudeerden in } 1992 * \star * \star *\end{array}$ & 2.2 & $\begin{array}{l}\text { matig arbeids- } \\
\text { marktperspectief }\end{array}$ \\
\hline
\end{tabular}

TYPERING

Matig arbeidsmarktperspectief met enige uitwijkmogelijkheden. 


\section{SOCIAAL-CULTURELE WETENSCHAPPEN}

Code(s): 671

\section{HISTORISCHE DATA}

I. Gemiddeld aantal werkenden 1979 - 1985*:

- absoluut aantal:

- in \% van het totaal aantal werkenden:

- in $\%$ van het totaal aantal werkenden met een universitaire opleiding :

29.900

$$
\begin{aligned}
& 0.59++ \\
& 14.2+
\end{aligned}
$$

II. Belangrijkste beroepsklassen warin men werkzaam is:

(gemiddeld percentage 1979 - $1985 *$ )

1. (19) Diverse wetenschappelijk e.a. vak-

2. (13) specialisten

3. (21) Beleidvoerende en hogere leidinggevende

$\underline{\text { trend }}$ **

4. (31) functies (excl. Openbaar bestuur)

4. (31) Uitvoerende hoofdambtenaren

5. (39) Diverse administratieve functies

6. (2) Architecten, ingenieurs en verwante functies

7. (15) Auteurs, journalisten e.d.

8. (6) Genees-, tandheelkundigen, dierenartsen,

9. (9) Economen

53

$24 \quad \overline{0}$

60

$\#$

$\#$

$\#$

III. Gemiddeld aandeel in de werkgelegenheid van de beroepsklasse 1979 - 1985*:

in \% van totaal aantal werkenden trend** in beroepsklasse

1. (19) Diverse wetenschappelijke

2. (13) Leerkrachten e.a. vakspecialisten

3. (21) Beleidvoerende en hogere leidinggevende functies (excl. openbaar bestuur)

16

3

$+$

1 


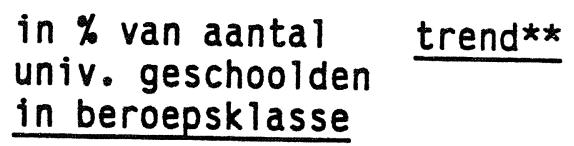

1. (19) Diverse wetenschappelijke

2. (13) Leerkrachten

63

$15++$

3. (21) Beleidvoerende en hogere leidinggevende functies (excl. (excl. openbaar bestuur)

10

0

IV. Werkloosheid (november/december):

- absoluut aantal in 1986: 5.358

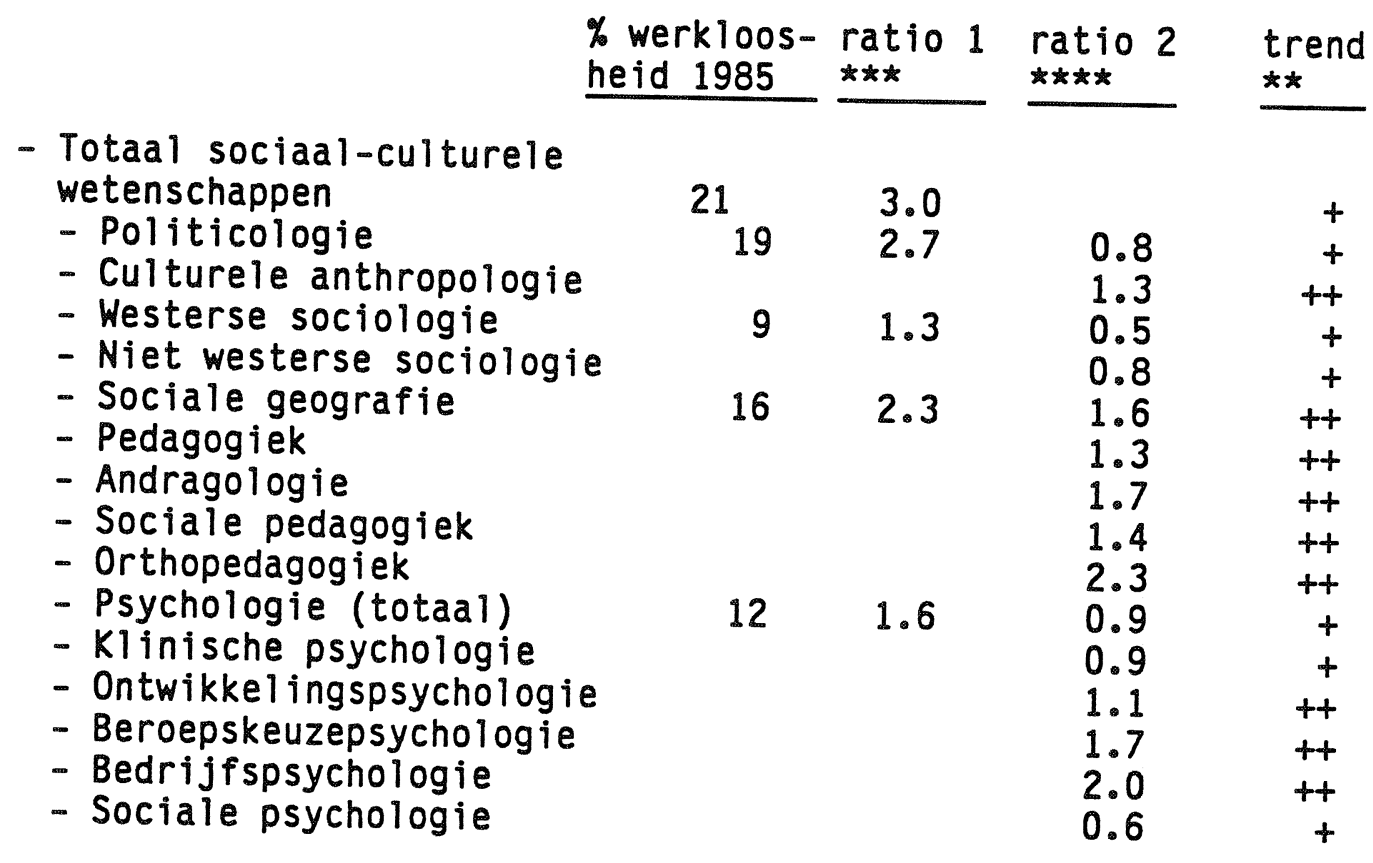

INDICATOREN

HG-ratio kwalificatie trend**

Beroepenspreiding:

(gemiddelde $1979-1985^{\star}$ ) 0.66 gemiddeld + 


\section{PROGNOSES}

Arbeidsmarktontwikkeling 1985 - 1992:

(in \% werkgelegenheid in 1985)

\begin{tabular}{|c|c|c|}
\hline & $\underline{\%}$ & kwal ificatie \\
\hline $\begin{array}{l}\text { Werkgelegenheidsontwikkeling } \\
\text { Vervangingsvraag } \\
\text { Totale vraag naar nieuwkomers }\end{array}$ & $\begin{array}{r}32 \\
\frac{8}{40}\end{array}$ & $\begin{array}{l}\text { hoog } \\
\text { gemiddeld } \\
\text { hoog }\end{array}$ \\
\hline Instroom afgestudeerden & 91 & erg hoog \\
\hline 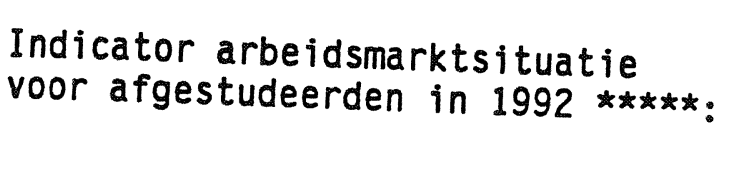 & 2.3 & $\begin{array}{l}\text { matig arbeids- } \\
\text { marktperspectief }\end{array}$ \\
\hline
\end{tabular}

\section{TYPERING}

Matig arbeidsmarktperspectief met enige uitwijkmogelijkheden. 
KUNSTONDERWIJS

Code (s): 686

HISTORISCHE DATA

trend**

I. Gemiddeld aantal werkenden 1979 - 1985*:

- absoluut aantal:

- in \% van het totaal aantal werkenden:

- in \% van het totaal aantal werkenden

1.600 met een universitaire opleiding :

$0.03+$

0.8

II. Belangrijkste beroepsklassen waarin men werkzaam is:

(gemiddeld percentage 1979 - $1985 *$ )

1. (19) Diverse wetenschappelijke e.a. vakspecialisten

2. (13) Leerkrachten

3. (16) Kunstschilders, fotografen e.a. beeldende kunstenaars

4. (17) Musici, toneelspelers e.a. uitvoerende kunstenaars

5. (15) Auteurs, journalisten e.d.

6. (39) Diverse administratieve functies

7. (59) Diverse dienstverlenende functies

8. (55) Huisbewaarders, schoonmaakpersonee

9. (20) Beleidvoerende en hogere leidinggevende functies bij openbaar bestuur

10. (31) Uitvoerende hoofdambtenaren

11. (47) Verzekeringsagenten, makelaars, veilinghouders e.d.

12. (42) Zelfstandige groothandelaren en tussenpersonen

13. (43) Zelfstandige winkeliers

14. (21) Beleidvoerende en hogere leidinggevende fun $\quad \mathrm{xcl}$. openbaar bestuur) 
IV. Werkloosheid (november/december):

- absoluut aantal in 1986: 475

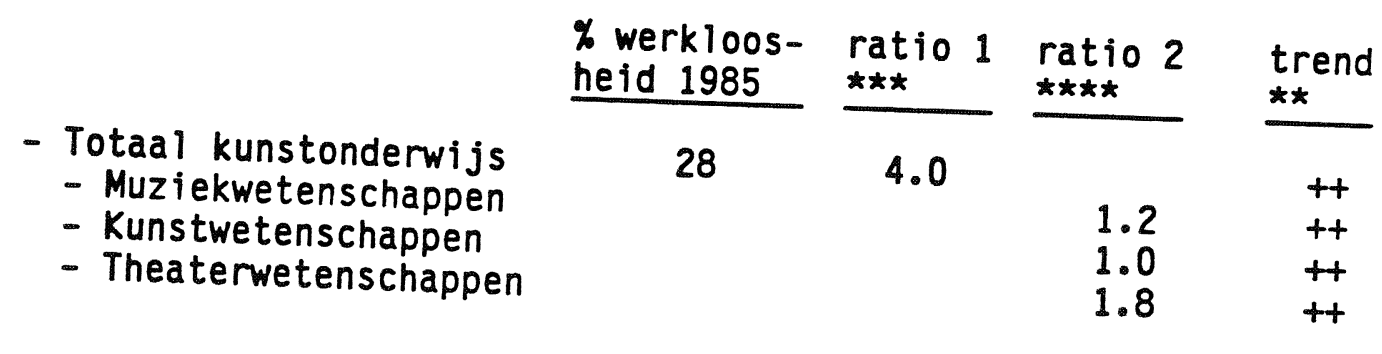

\section{INDICATOREN}

\begin{tabular}{|c|c|c|c|}
\hline & HG-ratio & kwalificatie & trend $* *$ \\
\hline $\begin{array}{l}\text { Beroepenspreiding: } \\
\text { (gemiddelde } 1979-1985^{\star} \text { ) }\end{array}$ & 0.79 & groot & + \\
\hline
\end{tabular}

\section{PROGNOSES}

Arbeidsmarktontwikkeling 1985 - 1992:

(in \% werkgelegenheid in 1985)

\begin{tabular}{|c|c|c|}
\hline & $\underline{\%}$ & kwalificatie \\
\hline $\begin{array}{l}\text { Werkgelegenheidsontwikkeling } \\
\text { Vervangingsvraag } \\
\text { Totale vraag naar nieuwkomers }\end{array}$ & $\begin{array}{r}15 \\
\frac{7}{23}\end{array}$ & $\begin{array}{l}\text { laag } \\
\text { laag } \\
\text { laag }\end{array}$ \\
\hline Instroom afgestudeerden & 224 & erg hoog \\
\hline $\begin{array}{l}\text { Indicator arbeidsmarktsituatie } \\
\text { yoor afgestudeerden in } 1992 \text { *****: }\end{array}$ & 9.9 & $\begin{array}{l}\text { erg slecht arbeids- } \\
\text { marktperspectief }\end{array}$ \\
\hline
\end{tabular}

TYPERING

Erg slecht arbeidsmarktperspectief met enige uitwijkmogelijkheden. 
MO-B AKTEN

Code (s): 606

HISTORISCHE DATA

I. Gemiddeld aantal werkenden 1979 - 1985*:

- absoluut aantal:

- in \% van het totaal aantal werkenden:

- in \% van het totaal aantal werkenden met een universitaire opleiding :

12.600

$\begin{array}{ll}0.25 & + \\ 2.4 & 0\end{array}$

II. Belangrijkste beroepsklassen waarin men werkzaam is:

(gemiddeld percentage $1979-1985^{\star}$ )

1. (13) Leerkrachten

2. (19) Diverse wetenschappelijke e.a. vak-

trend**

specialisten

3. (17) Uitvoerende kunstenaars

4. (21) Beleidvoerende en hogere leidinggevende functies (excl. openbaar bestuur)

$\begin{array}{cc}\% & \frac{\text { trend } * *}{86} \\ 0\end{array}$

III. Gemiddeld aandeel in de werkgelegenheid van de beroepsklasse 1979 - 1985*:

\section{in $\%$ van totaal trend** aantal werkenden in beroepsklasse}

1. (13) Leerkrachten

1. (13) Leerkrachten

INDICATOREN

HG-ratio kwalificatie trend**

Beroepenspreiding:

(gemiddelde 1979 - 1985*)

0.26

klein

0 


\section{PROGNOSES}

Arbeidsmarktontwikkeling 1985 - 1992:

(in \% werkgelegenheid in 1985)

Vervangingsheidsontwikkeling

Vervangingsvraag

$\underline{q}$

kwal ificatie

Totale vraag naar nieuwkomers

31

$\frac{6}{36}$

hoog

laag

gemiddeld 
BIJLAGE II: ARBEIDSMARKTDATA BEROEPSKLASSEN EN ENKELE SPECIFIEKE BEROEPSGROEPEN

Bron: ROA/CBS 


\begin{tabular}{|c|c|c|}
\hline & $\begin{array}{l}\text { Beroepen- } \\
\text { classifi- } \\
\text { catie-code* }\end{array}$ & \\
\hline Schei-, Natuurkundigen en verwante technici & 01 & 3 \\
\hline Architecten, Ingenieurs en verwante technici & $02 / 03$ & 6 \\
\hline $\begin{array}{l}\text { Biologen, Biochemici, Landbouwkundigen en } \\
\text { verwante vakspecialisten }\end{array}$ & 05 & 9 \\
\hline $\begin{array}{l}\text { Genees, Tandheelkundigen, Dierenartsen, } \\
\text { Verplegenden en verwante vakspecialisten }\end{array}$ & $06 / 07$ & 12 \\
\hline $\begin{array}{l}\text { Statistici, Wiskundigen, Systeemanalisten } \\
\text { en verwante vakspecialisten }\end{array}$ & 08 & 15 \\
\hline Economen & 09 & 18 \\
\hline Accountants & 11 & 21 \\
\hline Juristen & 12 & 23 \\
\hline Leerkrachten & 13 & 26 \\
\hline Theologen & 14 & 28 \\
\hline Auteurs, Journalisten e.d. & 15 & 30 \\
\hline $\begin{array}{l}\text { Kunstschilders, Fotografen, e.a. beeldende } \\
\text { kunstenaars }\end{array}$ & 16 & 32 \\
\hline $\begin{array}{l}\text { Diverse wetenschappelijke e.a. vakspecia- } \\
\text { listen }\end{array}$ & 19 & 34 \\
\hline $\begin{array}{l}\text { Beleidvoerende en hogere leidinggevende } \\
\text { functies bij openbaar bestuur }\end{array}$ & 20 & 37 \\
\hline $\begin{array}{l}\text { Beleidvoerende en hogere leidinggevende } \\
\text { functies (exclusief openbaar bestuur) }\end{array}$ & 21 & 39 \\
\hline Uitvoerende Hoofdambtenaren & 31 & 42 \\
\hline Secretaressen, Typisten e.d. & 32 & 44 \\
\hline Bankemployés, Lokettisten e.d. & 33 & 47 \\
\hline Diverse administratieve functies & 39 & 50 \\
\hline Directeuren en Bedrijfsleiders groothandel & 40 & 53 \\
\hline
\end{tabular}




\section{VERKLARING VAN DE GEBRUIKTE TEKENS}

* Gemiddelde op basis van de jaren 1979, 1981, 1983 en 1985.

** Op basis van een vr,rgelijking tussen de jaren 1983 en 1985 ten opzichte van de jaren 1979 en 1981.

$$
\begin{aligned}
+ & =\text { sterk stijgend } \\
+ & =\text { stijgend } \\
0 & =\text { constant } \\
- & =\text { dalend } \\
- & =\text { sterk dalend }
\end{aligned}
$$

Voor de hierbij gehanteerde classificatiecriteria zie bijlage
III.

\# Te gering percentage of aantal (zie paragraaf 2.1). 
SCHEI -, NATUURKUNDIGEN EN VERWANTE TECHNICI

Code: 01

\section{HISTORISCHE DATA}

trend $\star \star$

I. Gemiddeld aantal werkenden 1979-1985*: 33.200

Gemiddeld \% van het totaal aantal

werkenden 1979 - 1985*:

0.67

0

Gemiddeld aantal werkenden 1979 - 1985* in enkele specifieke beroepsgroepen:

- Scheikundigen (code 011):

- gemiddeld \% van het totaal aantal werkenden:

2.800

- Natuurkundigen (drs/ir) (code 012):

- gemiddeld \% van het totaal aantal werkenden:

$$
0.06
$$

1.700

$$
0.03
$$

- Geologen, meteorologen e.d. (code 013):

- gemiddeld \% van het totaal aantal werkenden:

0.02

$+$

II. Aandeel leeftijdsgroepen:

(gemiddeld percentage 1979 - 1985*)

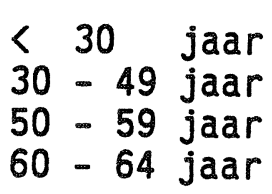

trend $* *$

37

48

13

\#

0

0

0 
III. Aandeel opleidingscategorieën:

(gemiddeld percentage 1979 - 1985*)

$\begin{array}{lcc} & \underline{\psi} & \text { trend } \star \star \\ \text { Universitair opgeleiden } & 16 & - \\ \text { HBO-ers } & 30 & + \\ \text { MBO-ers } & 28 & + \\ \text { LBO-ers } & 7 & + \\ \text { HAVO/VWO-ers } & \# & \\ \text { MAVO-ers } & 6 & -- \\ \text { Basis onderwijs } & \# & \end{array}$

IV. Belangrijkste bedrijfsklassen waarin men werkzaam is: (gemiddeld percentage 1979 - 1985*)

1. (20-22) Kwartaire sector

W.v. (22) Overheid

(20) Medische en veterinaire diensten

2. (2-12) Industrie en openbare nutsbedrijven

w.v. (6) Chemische, rubber- en kunststofverwerkende industrie

(2) Voedings - en genotmiddelenindustrie

3. (14-19) Commerciële diensten

$\underline{\%}$

trend $\star *$

45

22

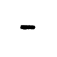

$+$

5

45

$\begin{array}{ll}20 & - \\ 8^{9} & +\end{array}$

V. Aandeel zelfstandigen (gemiddeld

$\underline{\%}$

percentage 1979 - 1985*):

0.1 
INDICATOREN

$$
\text { indicator kwalifi- trend } * *
$$

Vervangingsbehoefte ouderen

- Gemiddelde van 1979 - 1985*:

1.12 groot +

Absorptiegraad < 30 jarigen

- Gemiddelde van 1979 - 1985*:

1.25 groot 0

Branchespreiding

- Gemiddelde van 1979 - 1985*:

0.90 groot 0

Conjunctuurgevoeligheid

- Periode 1950 - 1985:

\section{$13.2 \%$ gemiddeld}

\section{PROGNOSES}

Arbeidsmarktontwikkelingen 1985 - 1992:

(in \% van werkgelegenheid in 1985)

Werkgel egenhe idsontwikkeling

Vervangingsvraag

Totale vraag naar nieuwkomers

\% kwalificatie

Vraag naar schoolverlaters

8 gemiddeld

$\frac{16}{24}$ laag

24 gemiddeld

16

gemiddeld

TYPERING Redelijk arbeidsmarktperspectief, weinig conjunctuurgevoelig en er
zijn ook uitwijkmogelijkheden. 
ARCHITECTEN, INGENIEURS EN VERWANTE TECHNICI

Code: $02 / 03$

\section{HISTORISCHE DATA}

I. Gemiddeld aantal werkenden 1979-1985*: 175.700 Gemiddeld \% van het totaal aantal werkenden 1979 - 1985*:

Gemiddeld aantal werkenden 1979 - 1985* in enkele specifieke beroepsgroepen.

- Architecten, stedebouwkundigen (code 021):

- gemiddeld \% van het totaal aantal werkenden:

Hoofden technische dienst (hoger) (code 024):

- gemiddeld \% van het totaal aantal werkenden:

- Hogere chemisch technologen (code 026):

- gemiddeld \% van het totaal aantal werkenden:

4.100

$0.08+$

- Hogere technisch natuurkundigen en metaalkundigen (code 027):

- gemiddeld \% van het totaal aantal werkenden:

- Hogere technici specialisaties n.e.g. (code 029):

- gemiddeld \% van het totaal aantal werkenden:

II. Aandeel leeftijdgroepen:

(gemiddeld percentage 1979 - 1985*)

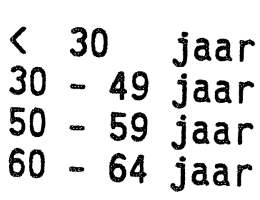


III. Aandeel opleidingscategorieën:

(gemiddeld percentage 1979 - 1985*)

\begin{tabular}{lcc} 
& $\underline{\%}$ & trend $\star \star$ \\
\cline { 2 - 2 } Universitair opgeleiden & 12 & ++ \\
HBO-ers & 32 & 0 \\
MBO-ers & 45 & 0 \\
LBO-ers & 6 & 0 \\
HAVO/VWO-ers & $\#$ & \\
MAVO-ers & $\#$ & \\
Basis onderwijs & $\#$ &
\end{tabular}

IV. Belangrijkste bedrijfsklassen waarin men werkzaam is: (gemiddeld percentage 1979 - 1985*)

\% $\quad$ trend **

1. (2-12) Industrie en openbare nutsbedrijven

w.v. (7/8) Basismetaal, metaal-

$36 \quad 0$

produkten- en optische industrie

(9) Electrotechnische industrie

2. (14-19) Commerciële diensten

3. (20-22) Kwartaire sector w.v. (22) Overheid

4. (13) Bouwnijverheid

$\begin{array}{rrrr} & & 10 & 0 \\ & 8 & 0 \\ 30 & & 0 \\ 18 & & 0 \\ & & 12 & 0 \\ & & & \\ 1 & & & 0\end{array}$

V. Aandeel zelfstandigen:

(gemiddeld percentage $1979-1985^{*}$ )

\section{INDICATOREN}

Vervangingsbehoefte ouderen

indicator kwalifi- trend ** catie

1.41 groot 0

Absorptiegraad < 30 jarigen

- Gemiddelde van 1979 - 1985*:

0.79 klein

Branchespreiding

- Gemiddelde van 1979 - 1985*

0.92 groot

0

Conjunctuurgevoeligheid

- Periode 1950 - 1985:

$14.9 \%$ gemiddeld 


\section{PROGNOSES}

Arbeidsmarktontwikkeling 1985 - 1992:

(in \% van werkgelegenheid in 1985)

Werkgelegenheidsontwikkeling

Vervangingsvraag

Totale vraag naar nieuwkomers

\section{\% $\quad$ kwalificatie}

12 hoog

12 laag

25 gemiddeld

Vraag naar schoolverlaters

20

hoog

\section{TYPERING}

Redelijk arbeidsmarktperspectief, weinig conjunctuurgevoelig en er
zijn ook uitwijkmogelijkheden. 
BIOLOGEN, BIOCHEMICI, LANDBOUWKUNDIGEN EN VERWANTE VAKSPECIALISTEN

Code: 05

\section{HISTORISCHE DATA}

trend $* \star$

I. Gemiddeld aantal werkenden 1979-1985*: 25.400

Gemiddeld \% van het totaal aantal

werkenden 1979 - 1985*:

0.50

Gemiddeld aantal werkenden 1979 - 1985* in enkele specifieke beroepsgroepen.

- Biologen, zoölogen, botanici e.d. (code 051):

- gemiddeld \% van het totaal aantal werkenden:

- Hogere biochemici, bacteriologen, farmacologen e.d. (code 052):

- gemiddeld \% van het totaal aantal werkenden:

- Hogere landbouwkundigen (code 053):

- gemiddeld \% van het totaal aantal werkenden:

3.000

0.08

II. Aandeel leeftijdgroepen:

(gemiddeld percentage 1979 - 1985*)

$$
\begin{aligned}
& 30 \text { jaar } \\
& 30-49 \text { jaar } \\
& 50-59 \text { jaar } \\
& 60-64 \text { jaar }
\end{aligned}
$$


III. Aandeel opleidingscategorieën:

(gemiddeld percentage 1979 - 1985*)

$\begin{array}{lcc} & \underline{\%} & \text { trend ** } \\ \text { Universitair opgeleiden } & 23 & - \\ \text { HBO-ers } & 44 & 0 \\ \text { MBO-ers } & 24 & 0 \\ \text { LBO-ers } & \# & \\ \text { HAVO/VWO-ers } & \# & \\ \text { MAVO-ers } & \# & \# \\ \text { Basis onderwijs } & \#\end{array}$

IV. Belangrijkste bedrijfsklassen waarin men werkzaam is:

(gemiddeld percentage 1979 - 1985*)

1. (20-22) Kwartaire sector

w.V. (20) Medische en veterinaire diensten

(22) Overheid

2. (2-12) Industrie en openbare nutsbedrijven

3. (14-19) Commerciële diensten

4. (1) Landbouw, visserij en bosbouw

\% trend $* \star$

$86 \quad 0$

47

$\begin{array}{ll}47 & + \\ 25 & 0\end{array}$

$6 \quad 0$

V. Aandeel zelfstandigen:

(gemiddeld percentage 1979 - 1985*)

$\underline{\%}$

trend**

0.3

0

$\#$

INDICATOREN

Vervangingsbehoefte ouderen

indicator kwalifi- trend ** catie

- Gemiddelde van 1979 - 1985*:

0.94 gemiddeld 0

Absorptiegraad $<30$ jarigen

- Gemiddelde van 1979 - 1985*:

1.63 erg groot 0

Branchespreiding

- Gemiddelde van 1979 - 1985*: 0.74 groot 0

Conjuncturargevoeligheid

- Periode 1950 - 1985:

$8.8 \% \quad$ klein 
PROGNOSES

Arbeidsmarktontwikkeling 1985 - 1992:

(in \% van werkgelegenheid in 1985)

kwalificatie

Werkgelegenheidsontwikkeling

Vervangingsvraag

16 hoog

$\frac{9}{25}$ erg laag

Totale vraag naar nieuwkomers

$\overline{25}$ gemidde ld

Vraag naar schoolverlaters

2

erg laag

TYPERING

Redelijk arbeidsmarktperspectief, weinig conjunctuurgevoelig en er zijn ook uitwijkmogelijkheden. 
GENEES-, TANDHEELKUNDIGEN, DIERENARTSEN, VERPLEGENDEN EN VERWANTE VAK-
SPECIALISTEN

Code: 06/07

\section{HISTORISCHE DATA}

I. Gemiddeld aantal werkenden 1979-1985*: 237.100

Gemiddeld \% van totaal aantal

werkenden 1979 - 1985*:

4.70

$++$

Gemiddeld aantal werkenden 1979 - 1985* in enkele specifieke beroepsgroepen.

- Geneeskundigen (code 061):

- gemiddeld \% van het totaal aantal werkenden:

22.600

Tandheelkundigen (code 063):

- gemiddeld \% van het totaal aantal werkenden:

4.900

$$
0.45+
$$

- Diergeneeskundigen (code 065):

- gemiddeld \% van het totaal aantal werkenden:

$$
0.10+
$$

2.000

$$
0.04 \quad 0
$$

- Apothekers (code 067):

- gemiddeld \% van het totaal aantal werkenden:

1.300

$0.03+$

II. Aandeel leeftijdgroepen:

(gemiddeld percentage 1979 - 1985*)

$$
\begin{aligned}
& 30 \text { jaar } \\
& 30-49 \text { jaar } \\
& 50-59 \text { jaar } \\
& 60-64 \text { jaar }
\end{aligned}
$$


III. Aandeel opleidingscategorieën:

(gemiddeld percentage 1979 - 1985*)

$\begin{array}{lcc} & \underline{\Psi} & \text { trend } * * \\ \text { Universitair opgeleiden } & 13 & - \\ \text { HBO-ers } & 17 & + \\ \text { MBO-ers } & 55 & 0 \\ \text { LBO-ers } & \# & - \\ \text { HAVO/VWO-ers } & 6 & \\ \text { MAVO-ers } & \# & \#\end{array}$

IV. Belangrijkste bedrijfsklassen waarin men werkzaam is: (gemiddeld percentage $1979-1985^{*}$ )
1. (20-22) Kwartaire sector W.V. (20) Medische en veterinaire
\% trend $* *$
0
$5^{83} \quad 0$
diensten
2. (14-19) Commerciële diensten
94
2. (14-19) Commerciële diensten
v. Aandeel zelfstandigen:
\% $\quad$ trend $* *$
(gemiddeld percentage 1979 - 1985*)
12.0
0

INDICATOREN

Vervangingsbehoefte ouderen

indicator kwalifi- trend **

- Gemiddelde van 1979 - 1985*:

0.83 klein +

Absorptiegraad < 30 jarigen

- Gemiddelde van 1979 - 1985*:

1.81 erg groot 0

Branchespreiding

- Gemiddelde van 1979 - 1985*:

$0.30 \quad k l e i n$

Conjunctuurgevoeligheid

- Periode 1950 - 1985:

$9.2 \% \quad$ klein 


\section{PROGNOSES}

Arbeidsmarktontwikkeling 1985 - 1992:

(in $\%$ van werkgelegenheid in 1985)

$\begin{array}{lcl} & \underline{\%} & \text { kwalificatie } \\ \text { Werkgelegenheidsontwikkeling } & 14 & \text { hoog } \\ \text { Vervangingsvraag } & 10 & \text { laag } \\ \text { Totale vraag naar nieuwkomers } & \frac{10}{25} & \text { gemiddeld } \\ \text { Vraag naar schoolverlaters } & 15 & \text { gemiddeld }\end{array}$

\section{TYPERING} Redelijk arbeidsmarktperspectief, weinig conjunctuurgevoelig, maar er
zijn ook weinig uitwijkmogelijkheden. 
STATISTICI, WISKUNDIGEN, SYSTEEMANALISTEN EN VERWANTE VAKSPECIALISTEN

Code: 08

HISTORISCHE DATA

trend $\star \star$

I. Gemiddeld aantal werkenden 1979-1985*: 40.000

Gemiddeld \% van het totaal aantal

werkenden 1979 - 1985*:

$0.79++$

Gemiddeld aantal werkenden 1979 - 1985* in enkele specifieke beroepsgroepen.

- Hogere statistici (code 081): $\quad 400$

- gemiddeld \% van het totaal aantal werkenden:

$0.01+$

- Wiskundigen, actuarissen (code 082): 1.000

- gemiddeld \% van het totaal aantal werkenden:

0.02

II. Aandeel leeftijdgroepen:

(gemiddeld percentage $1979-1985^{\star}$ )

$<30$ jaar

$\underline{\%}$

trend $* \star$

30 - 49 jaar

50 - 59 jaar

60 - 64 jaar

37

57

0

0

III. Aandeel opleidingscategorieën:

(gemiddeld percentage 1979 - 1985*)

$\begin{array}{lrc} & \underline{\%} & \text { trend ** } \\ \text { Universitair opgeleiden } & 10 & - \\ \text { HBO-ers } & 32 & 0 \\ \text { MBO-ers } & 32 & 0 \\ \text { LBO-ers } & \# & 0 \\ \text { HAVO/VWO-ers } & 14 & - \\ \text { MAVO-ers } & 5 & \\ \text { Basis onderwijs } & \# & \end{array}$


IV. Belangrijkste bedrijfsklassen waarin men werkzaam is: (gemiddeld percentage 1979 - 1985*)
1. (14-19) Cormerciële diensten W.V.
(18) Bank- en verzekerings- wezen
(15) Hande 1
2. (2-12) Industrie en openbare nutsbedrijuen
w.v. (7/8) Basismetaal, metaalpro- dukten- en optische industrie
(9) Electrotechnische industrie
3. (20-22) Kwartaire sector w.v. (22) Overheid
$\underline{\text { q }}$
trend $\star \star$
55
$+$
13
9
26

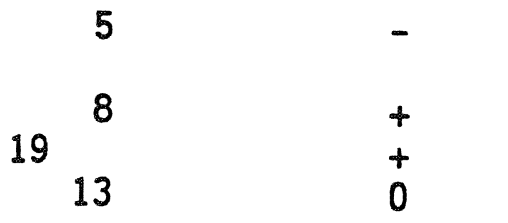
V. Aandeel zelfstandigen:
(gemiddeld percentage 1979 - 1985*)

\% trend $\star *$
1.4

\section{INDICATOREN}

Vervangingsbehoefte ouderen

- Gemiddelde van 1979 - 1985*:

indicator kwalifi- trend ** catie

0.87 klein ++

Absorptiegraad $<30$ jarigen

- Gemiddelde van 1979 - 1985*:

1.25 groot 0

Branchespreiding

- Gemiddelde van 1979 - 1985*: 0.90 groot 0

Conjunctuurgevoeligheid

- Periode 1950 - 1985:

$11.1 \%$ gemiddeld 


\section{PROGNOSES}

Arbeidsmarktontwikkeling 1985 - 1992:

(in \% van werkgelegenheid in 1985)

Werkgelegenheidsontwikkeling

kwalificatie

Vervangingsvraag

57

$\frac{3}{60}$

Totale vraag naar nieuwkomers

$\overline{60}$

erg hoog

erg laag

erg hoog

Vraag naar schoolverlaters

23

hoog

TYPERING

Goed arbeidsmarktperspectief, weinig conjunctuurgevoelig, er zijn ook
uitwijkmogelijkheden. 


\section{ECONOMEN}

\section{Code: 09}

\section{HISTORISCHE DATA}

trend $* *$

i. Gemiddeld aantal werkenden 1979-1985*: 13.700 Gemiddeld \% van het totaal aantal werkenden 1979 - 1985*:

II. Aandeel leeftijdgroepen:

(gemiddeld percentage 1979 - 1985*)

$$
\begin{aligned}
& <30 \text { jaar } \\
& 30-49 \text { jaar } \\
& 50-59 \text { jaar } \\
& 60-64 \text { jaar }
\end{aligned}
$$

III. Aandeel opleidingscategorieën:

(gemiddeld percentage 1979 - 1985*)

Universitair opgeleiden

HBO-ers

30

LBO-ers

HAVO/VWO-ers

MAVO-ers

Basis onderwijs

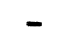

$+$

$++$ 
IV. Belangrijkste bedrijfsklassen waarin men werkzaam is: (gemiddeld percentage 1979 - 1985*)

1. (14-19) Commerciële diensten w.v. (18) Bank- en verzekerings-
wezen (15) Handel

2. (2-12) Industrie en openbare nutsbedrijven

w.v. (6) Chemische, rubber- en kunsts tofverwerkende industrie

3. (20-22) Kwartaire sector w.v. (22) Overheid

4. (13) Bouwnijverheid

V. Aandeel zelfstandigen:

(gemiddeld percentage 1979 - 1985*)

\section{INDICATOREN}

Vervangingsbehoefte ouderen

- Gemiddelde van 1979 - 1985*:

\section{indicator kwalifi- trend ** \\ catie}

1.87

erg groot+

Absorptiegraad $<30$ jarigen

- Gemiddelde van 1979 - 1985*:

0.91 gemiddeld -

Branchespreiding

- Gemiddelde van 1979 - 1985*:

0.92 groot

0

Conjunctuurgevoel igheid

- Periode 1950 - 1985:

$10.3 \%$ gemiddeld $\underline{\%}$

$\underline{\text { trend } \star *}$

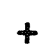

$-$

$+$

$+$

trend $* *$

6.1 


\section{PROGNOSES}

Arbeidsmarktontwikkeling 1985 - 1992:

(in \% van werkgelegenheid in 1985)

\% kwalificatie

Werkge legenheidsontwikkeling

26 erg hoog

Vervangingsvraag

12 laag

Totale vraag naar nieuwkomers

hoog

Vraag naar schoolverlaters

$8 \quad$ laag

TYPERING

Goed arbeidsmarktperspectief, weinig conjunctuurgevoelig, er zijn ook uitwijkmogelijkheden. 


\section{ACCOUNTANTS}

Code: 11

\section{HISTORISCHE DATA}

trend $* *$

I. Gemiddeld aantal werkenden 1979-1985*: 13.400

Gemiddeld \% van het totaal aantal

werkenden 1979 - 1985*:

0.26

0

II. Aandeel leeftijdgroepen:

(gemiddeld percentage $1979-1985^{\star}$ )

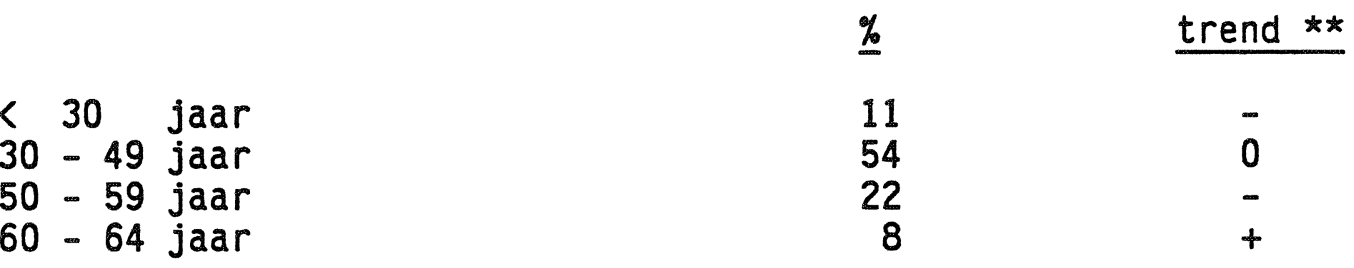

III. Aandeel opleidingscategorieën:

(gemiddeld percentage 1979 - 1985*)

Universitair opgeleiden
HBO-ers
MBO-ers
LBO-ers
HAVO/VWO-ers
MAVO-ers
Basis onderwijs

\% $\quad$ trend $* *$

IV. Belangrijkste bedrijfsklassen waarin men werkzaam is: (gemiddeld percentage 1979 - 1985*)

1. (14-19) Commerciële diensten

2. (20-22) Kwartaire sector W.V. (22) Overheid

3. (2-12) Industrie en openbare nutsbedrijven

V. Aandeel zelfstandigen:

(gemiddeld percentage 1979 - 1985*)
33

31

23

$\#$

$\#$

\#
$+$

$-$

$+$ $\underline{\%}$

trend $\star \star$

89

$\#$

\#

$\underline{\psi}$

39.4 trend $* *$

$++$ 


\section{INDICATOREN}

Vervangingsbehoefte ouderen

\begin{tabular}{|c|c|c|}
\hline indicator & $\begin{array}{l}\text { kwalifi- } \\
\text { catie }\end{array}$ & 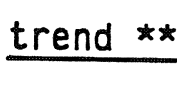 \\
\hline 3.16 & erg groot & 0 \\
\hline 0.44 & erg klein & - \\
\hline 0.31 & gemiddeld & - \\
\hline $6.3 \%$ & klein & \\
\hline
\end{tabular}

\section{PROGNOSES}

Arbeidsmarktontwikkeling 1985 - 1992:

(in \% van werkgelegenheid in 1985)

$\begin{array}{lll} & \underline{\%} & \text { kwalificatie } \\ \text { Werkgelegenheidsontwikkeling } & 25 & \text { erg hoog } \\ \text { Vervangingsvraag } & \frac{16}{41} & \begin{array}{l}\text { laag } \\ \text { Totale vraag naar nieuwkomers }\end{array} \\ \text { Vraag naar schoolverlaters } & 17 & \text { hoog }\end{array}$

TYPERING Goed arbeidsmarktperspectief, weinig conjunctuurgevoelig, er zijn ook
uitwijkmogelijkheden. 


\section{JURISTEN}

Code: 12

\section{HISTORISCHE DATA}

\section{trend $* \star$}

I. Gemiddeld aantal werkenden 1979-1985*: 15.800

Gemiddeld \% van het totaal aantal

werkenden 1979 - 1985*:

0.31

$++$

Gemiddeld aantal werkenden 1979 - 1985* in enkele specifieke beroepsgroepen.

- Advocaten, Officieren van Justitie e.d. (code 121):

3.900

- gemiddeld \% van het totaal aantal werkenden:
0.08
$+$

- Rechters (code 122):

- gemiddeld \% van het totaal aantal werkenden:

800

0.02

II. Aandeel leeftijdgroepen:

(gemiddeld percentage 1979 - 1985*)

$<30$ jaar

30 - 49 jaar

50 - 59 jaar

60 - 64 jaar

$\underline{\%}$

trend $\star \star$

III. Aandeel opleidingscategorieën:

(gemiddeld percentage $1979-1985^{\star}$ )

23

60

11

$-$

$+$

Universitair opgeleiden
HBO-ers
MBO-ers
LBO-ers
HAVO/VWO-ers
MAVO-ers
Basis onderwijs

$\underline{\%}$

trend **

83

80

$\overline{0}$ 
IV. Belangrijkste bedrijfsklassen waarin men werkzaam is:

(gemiddeld percentage 1979 - 1985*)
1. (14-19) Commerciële diensten W.V. (18) Bank- en verzekerings-
2. (20-22) Kwartaire sector w.v. (22) Overheid
3. (2-12) Industrie- en openbare nutsbedrijuen
V. Aandeel zelfstandigen:
(gemiddeld percentage $1979-1985^{\star}$ )

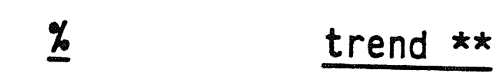
48
$46 \begin{array}{ll}6 & + \\ 40 & +\end{array}$
\#
\% trend **
19.5

\section{INDICATOREN}

Vervangingsbehoefte ouderen

indicator kwalifi- trend **

- Gemiddelde van 1979 - 1985*:

catie

2.03 erg groot ++

Absorptiegraad < 30 jarigen

- Gemiddelde van 1979 - 1985*:

1.10 gemiddeld -

Branchespreiding

- Gemiddelde van 1979 - 1985*:

0.71 groot

0

Conjunctuurgevoeligheid

- Periode 1950 - 1985:

\section{$6.2 \% \quad k i e i n$}

\section{PROGNOSES}

Arbeidsmarktontwikkeling 1985 - 1992:

(in \% van werkgelegenheid in 1985)

Werkgelegenheidsontwikkeling

Vervangingsvraag

Totale vraag naar nieuwkomers

kwalificatie

Vraag naar schoolverlaters

29

$\frac{8}{36}$

0

erg hoog

erg laag

hoog

nihil 
TYPERING Goed arbeidsmarktperspectief, weinig conjunctuurgevoelig, er zijn ook
uitwijkmogelijkheden. 


\section{LEERKRACHTEN}

Code: 13

\section{HISTORISCHE DATA}

I. Gemiddeld aantal werkenden 1979-1985*: 263.300 Gemiddeld \% van het totaal aantal werkenden 1979 - 1985*:

II. Aandeel leeftijdgroepen:

(gemiddeld percentage $1979-1985^{\star}$ )

30 jaar
$30-49$ jaar
$50-59$ jaar
$60-64$ jaar

III. Aandeel opleidingscategorieën:

(gemiddeld percentage $1979-1985^{\star}$ )

$\begin{array}{lcc} & \underline{\%} & \text { trend ** } \\ \text { Universitair opgeleiden } & 18 & + \\ \text { HBO-ers } & 69 & 0 \\ \text { MBO-ers } & 10 & - \\ \text { LBO-ers } & \# & \\ \text { HAVO/VWO-ers } & \# & \\ \text { MAVO-ers } & \# & \#\end{array}$

IV. Belangrijkste bedrijfsklassen waarin men werkzaam is: (gemiddeld percentage 1979 - 1985*)

1. (20-22) Kwartaire sector w.v. (22) Overheid

2. (14-19) Commerciële diensten

\begin{tabular}{cc}
\multicolumn{2}{c}{ trend ** } \\
98 \\
96 & 0 \\
\# & 0
\end{tabular}

V. Aandeel zelfstandigen:

(gemiddeld percentage 1979 - 1985*)

\section{$\underline{q}$}

trend $\star *$

1.0 


\section{INDICATOREN}

indicator kwalifi- trend **

Vervangingsbehoefte ouderen

catie

\subsection{1 groot +}

Absorptiegraad < 30 jarigen

- Gemiddelde van 1979 - 1985*:

1.10 gemiddeld --

Branchespreiding

- Gemiddelde van 1979 - 1985*:

Conjunctuurgevoeligheid

0.10 klein

- Periode 1950 - 1985:

$4.3 \%$ erg klein

\section{PROGNOSES}

Arbeidsmarktontwikkeling 1985 - 1992:

(in \% van werkgelegenheid in 1985)

Werkgel egenheidsontwikkeling

Vervangingsvraag

Totale vraag naar nieuwkomers

\% kwalificatie

12 groot

$\frac{11}{23} \quad$ laag

Yraag naar schoolverlaters

TYPERING

$10 \quad$ laag

Matig arbeidsmarktperspectief, weinig conjunctuurgevoelig, maar er
zijn ook weinig uitwijkmogelijkheden. 


\section{THEOLOGEN}

Code: 14

HISTORISCHE DATA

trend $\star *$

I. Gemiddeld aantal werkenden 1979-1985*: 8.900 Gemiddeld \% van het totaal aantal

werkenden 1979 - 1985*:

0.18

II. Aandeel leeftijdgroepen:

(gemiddeld percentage 1979 - 1985*)

$<30$ jaar

30 - 49 jaar

50 - 59 jaar

60 - 64 jaar

$\underline{\%}$

trend $\star *$

44

29

12

$\overline{0}$

$+$

III. Aandeel opleidingscategorieën:

(gemiddeld percentage $1979-1985^{\star}$ )

\%

trend **

Universitair opgeleiden

HBO-ers

49

MBO-ers

LBO-ers

HAVO/VWO-ers

MAVO-ers

Basis onderwijs

0

$+$

IV. Belangrijkste bedrijfsklassen waarin men werkzaam is: (gemiddeld percentage 1979 - 1985*)
1. (20-22) Kwartaire sector $w \cdot v$.
(20) Medische en
veterinaire diensten
(22) Overheid

$100 \begin{array}{cc}\% & \text { trend } * * \\ \# & 0\end{array}$

V. Aandeel zelfstandigen (gemiddeld percentage 1979 - 1985*): 
INDICATOREN

Vervangingsbehoefte ouderen

- Gemiddelde van 1979 - 1985*:

Absorptiegraad $<30$ jarigen

- Gemiddelde van 1979-1985*:

Branchespreiding

- Gemiddelde van 1979 - 1985*:

Conjunctuurgevoeligheid

- Periode 1950 - 1985: indicator kwalifi- trend **

catie

2.25 erg groot ++

0.32 erg klein ++

0.21 klein $\quad+$

$13.1 \%$ gemiddeld

\section{PROGNOSES}

Arbeidsmarktontwikkeling 1985 - 1992:

(in \% van werkgelegenheid in 1985)

Werkgelegenheidsontwikkeling

Vervangingsvraag

Totale vraag naar nieuwkomers

kwalificatie

Vraag naar schoolverlaters

$-1 \quad$ dalend

16 laag

$\overline{15}$ erg laag

TYPERING

Slecht arbeidsmarktperspectief, weinig conjunctuurgevoelig, maar er zijn ook weinig uitwijkmogelijkheden. 


\section{AUTEURS, JOURNALISTEN E.D.}

Code: 15

HISTORISCHE. DATA

trend $* *$

I. Gemiddeld aantal werkenden 1979-1985*: 16.800

Gemiddeld \% van het totaal aantal

werkenden 1979 - 1985*:

$0.34+$

II. Aandeel leeftijdgroepen:

(gemiddeld percentage 1979 - 1985*)

$<30$ jaar

30 - 49 jaar

50 - 59 jaar

60 - 64 jaar

\section{$\underline{\%}$}

25

54

13

III. Aandeel opleidingscategorieën:

(gemiddeld percentage 1979 - 1985*)

\begin{tabular}{|c|c|c|}
\hline & $\underline{\%}$ & trend $* *$ \\
\hline $\begin{array}{l}\text { Universitair opgeleiden } \\
\text { HBO-ers } \\
\text { MBO-ers } \\
\text { LBO-ers } \\
\text { HAVO/VWO-ers } \\
\text { MAVO-ers } \\
\text { Basis onderwijs }\end{array}$ & $\begin{array}{r}10 \\
32 \\
20 \\
\# \\
24 \\
7 \\
\#\end{array}$ & $\begin{array}{l}+ \\
+ \\
0 \\
-\end{array}$ \\
\hline
\end{tabular}

IV. Belangrijkste bedrijfsklassen waarin men werkzaam is:

(gemiddeld percentage $1979-1985^{\star}$ )

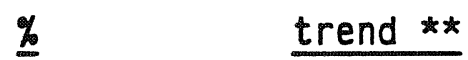

1. (2-12) Industrie en openbare nutsbedrijuen

w.v. (5) Papier- en grafische industrie

2. (20-22) Kwartaire sector w.v. (22) Overheid

3. (14-19) Commerciële diensten

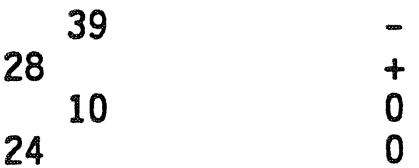


V. Aandeel zelfstandigen:

(gemiddeld percentage 1979 - 1985*)

$\underline{\text { q }}$

trend $\star *$

15.7

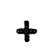

INDICATOREN

Vervangingsbehoefte ouderen

- Gemiddelde van 1979 - 1985*:

indicator kwalifi- trend ** catie

2.26 erg groot +

Absorptiegraad < 30 jarigen

- Gemiddelde van 1979-1985*:

$0.83 \quad k l e i n$

0

Branchespreiding

- Gemiddelde van 1979 - 1985*:

0.81 groot

0

Conjunctuurgevoeligheid

- Periode 1950 - 1985:

12.3\% gemiddeld

\section{PROGNOSES}

Arbeidsmarktontwikkeling 1985 - 1992:

(in \% van werkgelegenheid in 1985)

Werkgelegenheidsontwikkel ing

Vervangingsvraag

Totale vraag naar nieuwkomers

kwalificatie

Vraag naar schoolverlaters

16 hoog

6 erg laag

$\overline{22}$ laag

TYPERING

0 ninil

Matig arbeidsmarktperspectief, weinig conjunctuurgevoelig en er zijn ook uitwijkmogelijkheden. 
KUNSTSCHILDERS, FOTOGRAFEN, E.A. BEELDENDE KUNSTENAARS

Code: 16

\section{HISTORISCHE DATA}

trend $* \star$

I. Gemiddeld aantal werkenden 1979-1985*: 28.100

Gemiddeld \% van het totaal aantal

werkenden 1979 - 1985*:

0.56

0

II. Aandeel leeftijdgroepen:

(gemiddeld percentage 1979 - 1985*)

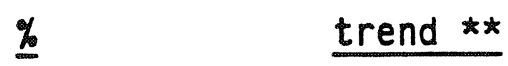

$<30$ jaar

30 - 49 jaar

50 - 59 jaar

60 - 64 jaar

$\begin{array}{ll}26 & - \\ 59 & + \\ 11 & ++\end{array}$

III. Aandeel opleidingscategorieën:

(gemiddeld percentage 1979 - 1985*)

\begin{tabular}{lrc} 
& \multicolumn{1}{c}{$\%$} & trend ** \\
Universitair opgeleiden & $\#$ & \\
HBO-ers & 36 & 0 \\
MBO-ers & 32 & 0 \\
LBO-ers & 10 & + \\
HAVO/VWO-ers & $\#$ & 0 \\
MAVO-ers & 7 & - \\
Basis onderwijs & 6 &
\end{tabular}

IV. Belangrijkste bedrijfsklassen waarin men werkzaam is:

(gemiddeld percentage 1979 - 1985*)

1. (14-19) Cormerciële diensten w.v. (15) Handel

2. (20-22) Kwartaire sector

$\underline{q}$

trend $* *$

3. (2-12) Industrie en openbare nutsbedrijuen

50

33

0

15

0

16

w.V. (5) Papier- en grafische industrie 
V. Aandeel zelfstandigen:

(gemiddeld percentage 1979 - 1985*)

\section{$\underline{\%}$}

trend **

46.7 indicator kwalifi- trend ** catie

1.06 gemiddeld +

0.80 klein

0.84 groot

0

Branchespreiding

- Gemiddelde van 1979 - 1985*:

$11.1 \%$ gemiddeld

Conjunctuurgevoeligheid

- Periode 1950 - 1985:

\section{PROGNOSES}

Arbeidsmarktontwikkeling 1985 - 1992:

(in \% van werkgelegenheid in 1985)

Werkgelegenheidsontwikkeling

Vervangingsuraag

Totale vraag naar nieuwkomers

kwalificatie

Vraag naar schoolverlaters

10

$\frac{18}{27}$

gemiddeld

gemidde ld

gemiddeld

\section{TYPERING}

14 laag

Redelijk arbeidsmarktperspectief, weinig conjunctuurgevoelig en er zijn ook uitwijkmogelijkheden. 


\section{DIVERSE WETENSCHAPPELIJKE E.A. VAKSPECIALISTEN}

Code: 19

HISTORISCHE DATA

trend $* *$

1. Gemiddeld aantal werkenden 1979-1985*: 97.900

Gemiddeld \% van het totaal aantal

werkenden 1979 - 1985*: $1.94 \quad$ t+

Gemiddeld aantal werkenden 1979 - 1985* in enkele specifieke beroepsgroepen:

- Sociologen, psychologen e.a. sociale wetenschapsbeoefenaren (code 192): 19.500

- gemiddeld \% van het totaal aantal werkenden:

- Taalkundigen, vertalers, tolken (code 195):

- gemiddeld \% van het totaal aantal werkenden:

II. Aandeel leeftijdgroepen:

(gemiddeld percentage 1979 - 1985*)

$$
\begin{aligned}
& 30 \text { jaar } \\
& 30-49 \text { jaar } \\
& 50-59 \text { jaar } \\
& 60-64 \text { jaar }
\end{aligned}
$$

III. Aandeel opleidingscategorieën:

(gemiddeld percentage 1979 - 1985*)

Universitair opgeleiden

HBO-ers

25

MBO-ers

LBO-ers

43

19

HAVO/VWO-ers

MAVO-ers

Basis onderwijs 
IV. Belangrijkste bedrijfsklassen waarin men werkzaam is: (gemiddeld percentage 1979 - 1985*)

\begin{tabular}{|c|c|c|c|}
\hline & & $\underline{z}$ & trend $* \star$ \\
\hline $\begin{array}{l}\text { 1. }(20-22) \\
w \cdot v\end{array}$ & $\begin{array}{l}\text { Kwartaire sector } \\
\text { (22) Overheid } \\
\text { (20) Medische en veterinaire }\end{array}$ & 8430 & $\begin{array}{l}0 \\
0\end{array}$ \\
\hline $\begin{array}{l}\text { 2. }(14-19) \\
\text { 3. }(2-12)\end{array}$ & $\begin{array}{l}\quad \text { diensten } \\
\text { Commerciële diensten } \\
\text { Industrie en openbare } \\
\text { nutsbedrijven }\end{array}$ & $11^{10}$ & $\overline{+}$ \\
\hline & & $\underline{\%}$ & trend $* \star$ \\
\hline $\begin{array}{l}\text { Aandeel ze } \\
\text { (gemiddeld }\end{array}$ & $\begin{array}{l}\text { Ifstandigen: } \\
\text { percentage } 1979-1985^{\star} \text { ) }\end{array}$ & 3.0 & + \\
\hline
\end{tabular}

INDICATOREN

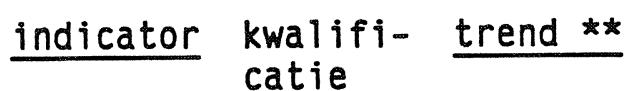

Vervangingsbehoefte ouderen

- Gemiddelde van 1979 - 1985*:

1.93 erg groot ++

Absorptiegraad $<30$ jarigen

- Gemiddelde van 1979-1985*:

1.14 groot

Branchespreiding

- Gemiddelde van 1979 - 1985*:

0.86 groot

0

Conjunctuurgevoeligheid

- Periode 1950 - 1985:

$9.7 \%$ groot

\section{PROGNOSES}

Arbeidsmarktontwikkeling 1985 - 1992:

(in \% van werkgelegenheid in 1985)

Werkgelegenheidsontwikkeling

Vervangingsuraag

Totale vraag naar nieuwkomers

kwalificatie

Vraag naar schoolverlaters

10 gemiddeld

9 erg laay

$\overline{19} \quad$ laag

0 nihil 
36

TYPERING

Matig arbeidsmarktperspectief, weinig conjunctuurgevoelig en er zijn ook ui twijkmogelijkheden. 
BELEIDVOERENDE EN HOGERE LEIDINGGEVENDE FUNCTIES BIJ OPENBAAR BESTUUR

Code: 20

HISTORISCHE DATA

trend $* *$

I. Gemiddeld aantal werkenden 1979-1985*: 4.300

Gemiddeld \% van het totaal aantal

werkenden 1979 - 1985*:

0.09

Gemiddeld aantal werkenden 1979 - 1985* in enkele specifieke beroepsgroepen.

- Beleidvoerende en leidinggevende hoofdambtenaren bij openbaar bestuur (code 202):

- gemiddeld \% van het totaal aantal werkenden:

0.03

$+$

II. Aandeel leeftijdgroepen:

(gemiddeld percentage 1979 - 1985*)

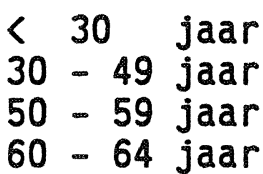

$\underline{\%}$

trend $\star \star *$

$\#$

$49 \quad 0$

$31 \quad-$

III. Aandeel opleidingscategorieën:

(gemiddeld percentage 1979 - 1985*)

$\underline{\underline{z}}$

trend $* *$

Universitair opgeleiden

HBO-ers

MBO-ers

LBO-ers

HAVO/VWO-ers

MAVO-ers

Basis onderwijs

41

28

\#

-

$+$ 
IV. Belangrijkste bedrijfsklassen waarin men werkzaam is: (gemiddeld percentage $1979-1985^{\star}$ )

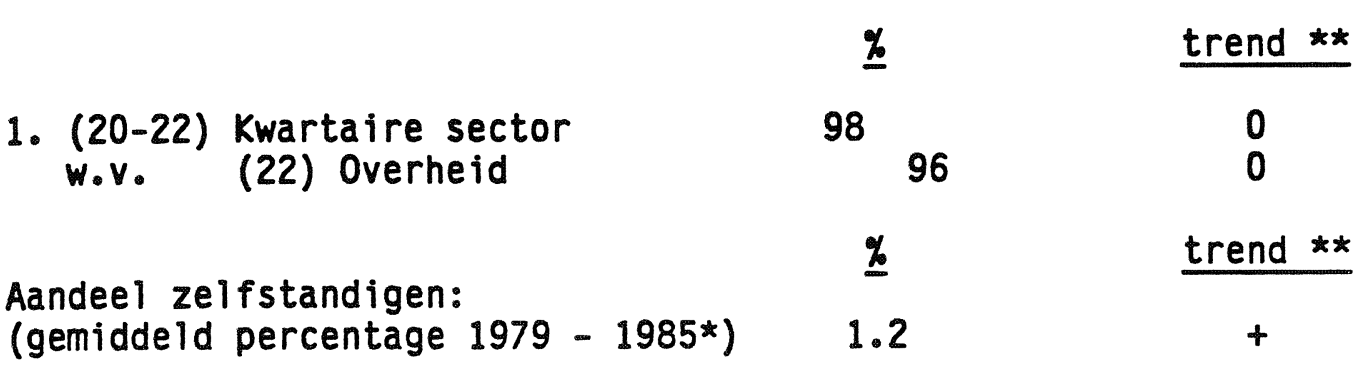

INDICATOREN

Vervangingsbehoefte ouderen

- Gemiddelde van 1979 - 1985*:

indicator kwalifi- trend **

catie

4.81 erg groot +

Absorptiegraad < 30 jarigen

- Gemiddelde van 1979 - 1985*:

0.10 erg klein ++

Branchespreiding

- Gemiddelde van 1979 - 1985*:

0.09 klein

$4.5 \%$ erg klein

Conjunctuurgevoeligheid

- Periode 1950 - 1985:
\% kwalificatie

14 hoog

28 erg hoog

$\overline{43} \quad$ erg hoog

0 nihil

Vraag naar schoolverlaters

TYPERING

Goed arbeidsmarktperspectief, weinig conjunctuurgevoelig, maar er zijn ook weinig uitwijkmogelijkheden. 
BELEIDVOERENDE EN HOGERE LEIDINGGEVENDE FUNCTIES (EXCLUSIEF OPENBAAR BESTUUR)

Code: 21

HISTORISCHE DATA

I. Gemiddeld aantal werkenden 1979-1985*: 142.400

trend $\star \star$

Gemiddeld \% van het totaal aantal

werkenden 1979 - 1985*:

2.82

$+$

II. Aandeel leeftijdgroepen:

(gemiddeld percentage 1979 - 1985*)

$<30$ jaar

30 - 49 jaar

50 - 59 jaar

60 - 64 jaar

$\underline{\%}$

trend $\star \star$

6

63

25

5

$\overline{0}$

0

0

III. Aandeel opleidingscategorieën:

(gemiddeld percentage 1979 - 1985*)

Universitair opgeleiden

$\underline{\%}$

trend $* *$

HBO-ers

MBO-ers

LBO-ers

HAVO/VWO-ers

MAVO-ers

12

0

25

37

-

Basis onderwijs 
IV. Belangrijkste bedrijfsklassen waarin men werkzaam is: (gemiddeld percentage 1979 - 1985*)

1. (2-12) Industrie en openbare nutsbedrijuen

$$
\begin{aligned}
& \text { w.v. (7/8) Basismetaal, metaalpro- } \\
& \text { dukten-en optische }
\end{aligned}
$$

2. (14-19) Commerciële diensten $w \cdot v$.

$$
\begin{aligned}
& \text { (17) Overige transport, } \\
& \text { opslag-en communi- }
\end{aligned}
$$

3. (13) Bouwnijverhebedrijuen

4. (20-22) Kwartaire sector

5. (1) Landbouw, bosbouw en visserij

$\underline{q}$

35

$318 \quad 0$

$\begin{array}{rrr} & 7 & ++ \\ 16 & & 0 \\ 15 & & -\end{array}$

V. Aandeel zelfstandigen:

(gemiddeld percentage 1979 - 1985*)

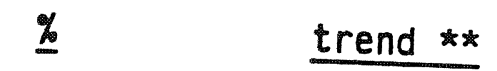

18.4

\section{INDICATOREN}

Vervangingsbehoefte ouderen

- Gemiddelde van 1979 - 1985*:

indicator kwalifi- trend **

Absorptiegraad $<30$ jarigen

2.48 erg groot +

- Gemiddelde van 1979 - 1985*:

0.23 erg klein _-

Branchespreiding

- Gemiddelde van 1979 - 1985*:

Conjunctuurgevoeligheid

0.98 groot 0

- Periode 1950 - 1985:

$14.8 \%$ gemiddeld 


\section{PROGNOSES}

Arbeidsmarktontwikkeling 1985 - 1992:

(in \% van werkgelegenheid in 1985)

\% kwalificatie

Werkgelegenheidsontwikkel ing

Vervangingsvraag

Totale vraag naar nieuwkomers

$7 \quad$ laag

$\frac{72}{19} \quad$ laag

$\frac{1}{19} \quad$ lagg

Vraag naar schoolverlaters

0

nihil

\section{TYPERING}

Matig arbeidsmarktperspectief, weinig conjunctuurgevoelig en er zijn ook uitwijkmogelijkheden. 
UITVOERENDE HOOFDAMBTENAREN

Code: 31

\section{HISTORISCHE DATA}

trend $* \star$

I. Gemiddeld aantal werkenden 1979-1985*: 18.200

Gemiddeld \% van het totaal aantal
werkenden 1979 - 1985*:
0.36

II. Aandeel leeftijdgroepen:

(gemiddeld percentage 1979 - 1985*)

\begin{tabular}{llrc} 
& & \multicolumn{1}{c}{} & trend ** \\
$<30$ jaar & 7 & - \\
$30-49$ jaar & 60 & + \\
$50-59$ jaar & 28 & - \\
$60-64$ jaar & 6 & +
\end{tabular}

III. Aandeel opleidingscategorieën

(gemiddeld percentage 1979 - 1985*)

Universitair opgeleiden

HBO-ers

MBO-ers

LBO-ers

HAVO/VWO-ers

MAVO-ers

Basis onderwijs

\section{$\underline{\%}$}

trend **

IV. Belangrijkste bedrijfsklassen waarin men werkzaam is: (gemiddeld percentage 1979 - 1985*)

26
34
30
$\#$
$\#$
$\#$
$\#$

$+$

0

0
1. (20-22) Kwartaire sector w.V.
(22) Overheid
2. (14-19) Cormerciële diensten
3. $(2-12)$ Industrie en openbare nutsbedrijven

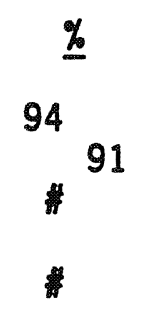
$\underline{\boldsymbol{q}}$
V. Aandeel zelfstandigen:
(gemiddeld percentage 1979 - 1985*)
trend $\star *$
0
$+$ 


\section{INDICATOREN}

Vervangingsbehoefte ouderen

- Gemiddelde van 1979 - 1985*:

indicator kwalifi- trend ** catie

3.07 erg groot -

Absorptiegraad $<30$ jarigen

- Gemiddelde van 1979 - 1985*:

0.26 erg klein --

Branchespreiding

- Gemiddelde van 1979 - 1985*:

0.19 klein

Conjunctuurgevoeligheid

- Periode 1950 - 1985:

$4.2 \%$ erg klein

\section{PROGNOSES}

Arbeidsmarktontwikkeling 1985 - 1992:

(in \% van werkgelegenheid in 1985)

\% kwalificatie

Werkgelegenheidsontwikkeling

25 erg hoog

Vervangingsvraag

Totale vraag naar nieuwkomers

22 hoog

$\frac{22}{47} \quad$ erg hoog

Vraag naar schoolverlaters

41

erg hoog

TYPERING

Goed arbeidsmarktperspectief, weinig conjunctuurgevoelig maar er zijn ook weinig uitwijkmogelijkheden. 
SECRETARESSEN, TYPISTEN E.D.

Code: 32

\section{HISTORISCHE DATA}

trend $\star \star$

I. Gemiddeld aantal werkenden 1979-1985*: 139.200

Gemiddeld \% van het totaal aantal

werkenden 1979 - 1985*:

2.76

0

II. Aandeel leeftijdgroepen:

(gemiddeld percentage 1979 - 1985*)

30 jaar
$30-49$ jaar
$50-59$ jaar
$60-64$ jaar

$\underline{\%}$

trend $* \star$

$+$

III. Aandeel opleidingscategorieën:

(gemiddeld percentage 1979 - 1985*)

$\underline{q}$

$\underline{\text { trend } * *}$

Universitair opgeleiden

HBO-ers

MBO-ers

LBO-ers

HAVO/VWO-ers

MAVO-ers

Basis onderwijs 
IV. Belangrijkste bedrijfsklassen waarin men werkzaam is: (gemiddeld percentage 1979 - 1985*)

\% $\quad$ trend $* \star$

1. (14-19) Commerciële diensten w.v. (15) Handel

(18) Bank- en verzekeringswezen

2. (20-22) Kwartaire sector w.v. (22) Overheid

(20) Medische en veterinaire diensten

3. (2-12) Industrie en openbare nutsbedrijven w.v. (7/8) Basismetaal, metaalprodukten- en optische industrie

4. (13) Bouwnijverheid

v. Aandeel zelfstandigen:

(gemiddeld percentage 1979 - 1985*)
43 11

0

$\begin{array}{rrr} & 9 & - \\ & & \\ & & \\ & & +\end{array}$

10

19

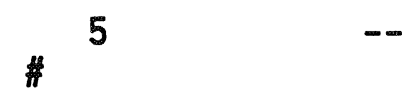

$\underline{\%}$

trend $* *$
$-$
$+$

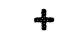

\section{INDICATOREN}

Vervangingsbehoefte ouderen

- Gemiddelde van 1979 - 1985*:

Absorptiegraad $<30$ jarigen

- Gemiddelde van 1979 - 1985*:

Branchespreiding

- Gemiddelde van 1979 - 1985*:

Conjunctuurgevoeligheid indicator kwalifi- trend ** catie

0.51 klein +

1.57 erg groot 0

0.94 groot 0

$10.4 \%$ gemiddeld 


\section{PROGNOSES}

Arbeidsmarktontwikkeling 1985 - 1992:

(in \% van werkgelegenheid in 1985)

\section{\% $\quad$ kwalificatie}

Werkgelegenheidsontwikkeling

14 hoog

22 hoog

Vervangingsvraag

Totale vraag naar nieuwkomers

35 hoog

Vraag naar schoolverlaters

30 erg hoog

\section{TYPERING}

Goed arbeidsmarktperspectief, weinig conjunctuurgevoelig, er zijn ook uitwijkmogelijkheden. 
BANKEMPLOYÉS, LOKETTISTEN E.D.

Code: 33

HISTORISCHE DATA

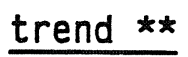

I. Gemiddeld aantal werkenden 1979-1985*: 279.600

Gemiddeld \% van het totaal aantal

werkenden 1979 - 1985*:

5.55

0

II. Aandeel leeftijdgroepen:

(gemiddeld percentage 1979 - 1985*)

\begin{tabular}{llcc} 
& $\underline{\%}$ & trend $\star *$ \\
\hline 30 & jaar & 47 & 0 \\
$30-49$ jaar & 39 & + \\
$50-59$ jaar & 11 & - \\
$60-64$ jaar & $\#$ &
\end{tabular}

III. Aandeel opleidingscategorieën:

(gemiddeld percentage 1979 - 1985*)

$\underline{\%}$

trend $* *$

Universitair opgeleiden

HBO-ers

MBO-ers

LBO-ers

HAVO/VWO-ers

MAVO-ers

Basis onderwijs

$\#$
6
41
14
11
17
6

+
0
+
+
-
- 
IV. Belangrijkste bedrijfsklassen waarin men werkzaam is:

(gemiddeld percentage 1979 - 1985*)

\% $\quad$ trend $* *$

1. (14-19) Commerciële diensten

$64 \quad 0$

w.v. (18) Bank- en verzekeringswezen

(15) Hande 1

27

$18+$

(17) Overige transport-, opslag en communicatiebedrijuen

2. (20-22) Kwartaire sector

$$
\text { W.V. (22) Overheid }
$$

3. (2-12) Industrie en openbare nutsbedrijuen

4. (13) Bouwnijverheid

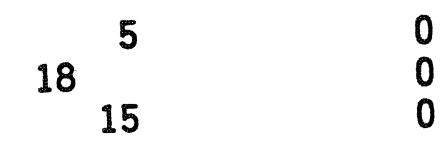

12

$\#$

\% trend $* *$

V. Aandeel zelfstandigen:

(gemiddeld percentage $1979-1985^{\star}$ ) 0.8

\section{INDICATOREN}

Vervangingsbehoefte ouderen

- Gemiddelde van 1979 - 1985*:

Absorptiegraad $<30$ jarigen

- Gemiddelde van 1979-1985*:

Branchespreiding

- Gemiddelde van 1979 - 1985*:

Conjunctuurgevoeligheid

- Periode 1950 - 1985: indicator kwalifi- trend ** catie

1.12 groot

1.25 groot

0

0.90 groot

0

$10.0 \%$ gemiddeld 


\section{PROGNOSES}

Arbeidsmarktontwikkeling 1985 - 1992:

(in \% van werkgelegenheid in 1985)

\% $\quad$ kwalificatie

Werkgelegenheidsontwikkeling

12 hoog

Vervangingsuraag

16 laag

Totale vraag naar nieuwkomers

$\overline{28}$ gemiddeld

Vraag naar schoolverlaters

24 hoog

TYPERING

Redelijk arbeidsmarktperspectief, weinig conjunctuurgevoelig en er zijn ook uitwijkmogelijkheden. 


\section{DIVERSE ADMINISTRATIEVE FUNCTIES}

Code: 39

\section{HISTORISCHE DATA}

trend **

I. Gemiddeld aantal werkenden 1979-1985*: 388.400

Gemiddeld \% van het totaal aantal werkenden 1979 - 1985*:

II. Aandeel leeftijdgroepen:

(gemiddeld percentage 1979 - 1985*)

$<30$ jaar

30 - 49 jaar

50 - 59 jaar

60 - 64 jaar

$\underline{\%}$

44

40

13

$\#$

III. Aandeel opleidingscategorieën:

(gemiddeld percentage 1979 - 1985*)

Universitair opgeleiden

HBO-ers

MBO-ers

LBO-ers

HAVO/VWO-ers

MAVO-ers

Basis onderwijs 
IV. Belangrijkste bedrijfsklassen waarin men werkzaam is: (gemiddeld percentage 1979 - 1985*)

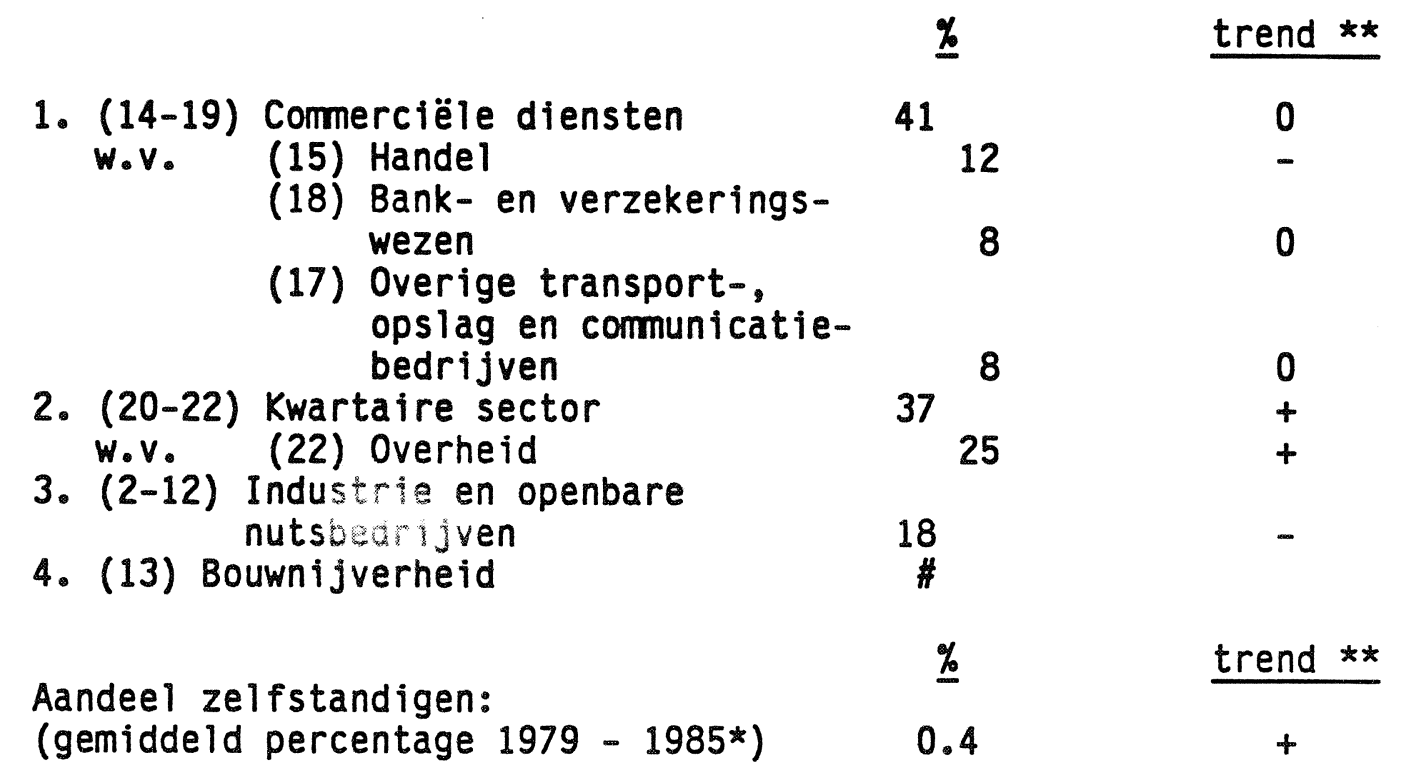

INDICATOREN

Vervangingsbehoefte ouderen

$\begin{array}{rlc}\text { indicator } & \begin{array}{l}\text { kwalifi- } \\ \text { catie }\end{array} & \text { trend ** } \\ 1.18 & \text { groot } & - \\ 1.17 & \text { groot } & 0\end{array}$

$\frac{\text { Absorptiegraad }<30 \text { jarigen }}{- \text { Gemiddelde van } 1979-1985 *}$

1.17 groot 0

Branchespreiding

- Gemiddelde van 1979 - 1985*:

0.94 groot

Conjunctuurgevoeligheid

- Periode 1950 - 1985:

$9.8 \%$ klein 


\section{PROGNOSES}

Arbeidsmarktontwikkeling 1985 - 1992:

(in \% van werkgelegenheid in 1985)

$\begin{aligned} \underline{*} & \text { kwalificatie } \\ 9 & \text { gemiddeld } \\ \frac{16}{25} & \text { laag } \\ 21 & \text { gemiddeld } \\ & \text { hoog }\end{aligned}$

TYPERING

Redelijk arbeidsmarktperspectief, weinig conjunctuurgevoelig en er zijn ook uitwijkmogelijkheden. 


\section{DIRECTEUREN EN BEDRIJFSLEIDERS GROOTHANDEL}

Code: 40

\section{HISTORISCHE DATA}

trend $\star *$

I. Gemiddeld aantal werkenden 1979-1985*: 23.500 Gemiddeld \% van het totaal aantal werkenden 1979 - 1985*:

II. Aandeel leeftijdgroepen: (gemiddeld percentage 1979 - 1985*)

30 jaar
$30-49$ jaar
$50-59$ jaar
$60-64$ jaar

\section{$\underline{\%}$}

trend **

III. Aandeel opleidingscategorieën: (gemiddeld percentage 1979 - 1985*)

Universitair opgeleiden

HBO-ers

MBO-ers

LBO-ers

HAVO/VWO-ers

MAVO-ers

Basis onderwijs

$\begin{array}{rr}5 & - \\ 16 & ++ \\ 42 & 0 \\ 8 & - \\ 11 & 0 \\ 9 & 0 \\ 6 & -\end{array}$

IV. Belangrijkste bedrijfsklassen waarin men werkzaam is: (gemiddeld percentage 1979 - 1985*)
$\underline{\%}$
trend $* *$
1. (14-19) Commerciële diensten w.v. (15) Handel
100 99 0
V. Aandeel zelfstandigen:
(gemiddeld percentage 1979 - 1985*) 
INDICATOREN

Vervangingsbehoefte ouderen

- Gemiddelde van 1979 - 1985*:

Absorptiegraad $<30$ jarigen

- Gemiddelde van 1979 - 1985*:

Branchespreiding

- Gemiddelde van 1979 - 1985*:

Conjunctuurgevoeligheid

- Periode 1950 - 1985:

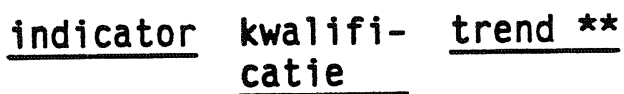

2.46 erg groot ++

0.22 erg klein --

0.03 klein

$11.6 \%$ gemiddeld

\section{PROGNOSES}

Arbeidsmarktontwikkeling 1985 - 1992:

(in \% van werkgelegenheid in 1985)

Werkgelegenheidsontwikkeling

Vervangingsuraag

Totale vraag naar nieuwkomers

kwalificatie

Vraag naar schoolverlaters

$\begin{aligned} 19 & \text { hoog } \\ \frac{8}{26} & \text { erg laag } \\ & \text { gemiddeld }\end{aligned}$

\section{TYPERING}

Redelijk arbeidsmarktperspectief, weinig conjunctuurgevoelig, maar er zijn ook weinig uitwijkmogelijkheden. 
BIJLAGE III: CLASSIFICATIE-CRITERIA HISTORISCHE TRENDS 
Bij de typering van de trendmatige ontwikkelingen over de periode 1979-'85 i? in het algemeen de volgende indeling van de trend-indices gehanteerd:

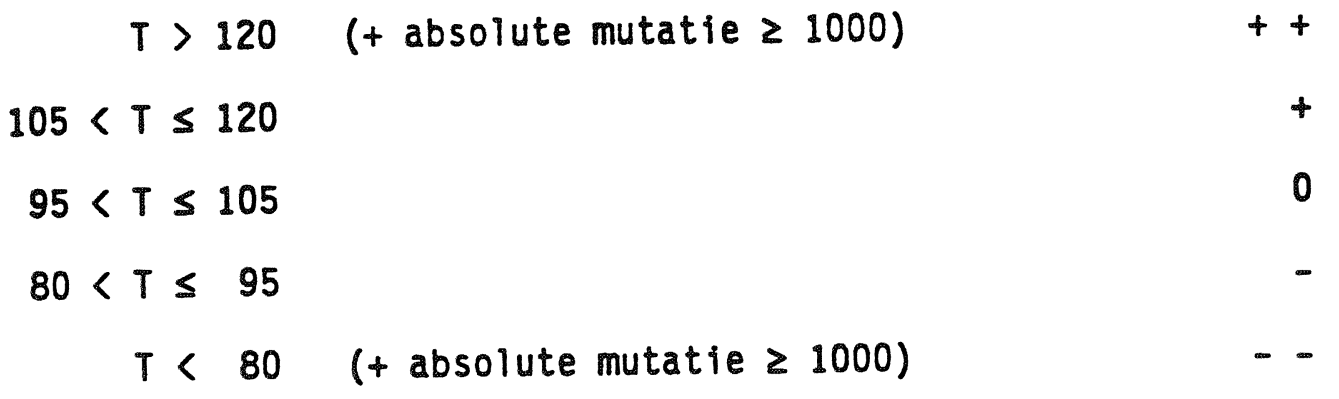

Bij de studierichingen zijn hierop enkele uitzonderingen gemaakt:

ad I: antal werkenden in $\%$ total:

$$
\begin{aligned}
T & >130(+ \text { absolute mutatie } \geq 1000)++ \\
105<T & \leq 130
\end{aligned}
$$

ad III: Werkgelenheid in $\%$ van totaal aantal werkenden in beroepsklasse:

$$
\begin{aligned}
T & >150(+ \text { absolute mutatie } \geq 1000) \\
105<T & \leq 150 \\
95<T & \leq 105 \\
50<T & \leq 95 \\
T & \leq 50 \text { (+ absolute mutatie } \geq 1000)
\end{aligned}
$$

ad IV: Werkloosheid:

$$
\begin{aligned}
T & \geq 250 \\
100 \leq T & <250
\end{aligned}
$$$$
+
$$ 